Universidade de São Paulo

Instituto de Química de São Carlos

EDUAR D O R O RIGUES DA SIL V A

Desenvolvimento de metodologia de baixo custo para determinação de glifosato usando microdispositivos eletroforéticos fabricados em poliéster-toner 
Universidade de São Paulo

Instituto de Química de São Carlos

E D U A R O R O D RIGUES DA SILVA

\section{Desenvolvimento de metodologia de baixo custo para determinação de glifosato usando microdispositivos eletroforéticos fabricados em poliéster-toner}

Dissertação apresentada ao Instituto de Química de São Carlos da Universidade de São Paulo para obtenção do título de Mestre em Ciências.

Área de Concentração: Química Analítica

Orientador: Prof. Dr. Luiz Henrique Mazo

São Carlos

2011 


\section{Agradecimentos}

Inicialmente agradeço a Deus pela benção com todas as virtudes necessárias para desenvolvimento desse trabalho, e para superação dos diversos obstáculos encontrados...

Agradeço a todos meus familiares (Pai, Mãe, Avó, Irmãos, Tios, Tias, Primos...) pela parcela de contribuição de cada um no desenvolvimento de meu caráter e de meus valores... Um agradecimento em especial a minha Mãe e minha Avó, mulheres que pra mim sempre foram símbolos de humanismo.

A minha noiva Ana Paula pelo companheirismo e carinho, sem ela tudo teria sido mais difícil.

Ao Professor Luiz Henrique Mazo pela orientação.

Ao Professor Emanuel Carrilho pela grande contribuição, ensinamentos e confiança depositada.

Ao Professor Sergio Spinola pela contribuição e apoio, sempre se mostrando prestativo em sanar as duvidas de seus curiosos, e muitas vezes ingênuos alunos.

Aos amigos do GMEME, pelas conversas cientificamente produtivas e pelos momentos de descontração. Um agradecimento em especial ao amigo "Murilão" que de certa forma contribuiu diretamente com este trabalho, e ao amigo Fernando que sempre se mostrou disposto a colaborar com novas ideias.

Aos amigos Dyovani, Deodato, Lívia e "Diegão" que sempre deixaram o ambiente de trabalho bem menos maçante, na verdade quase cômico... Ao amigo de longa data "Murilinho" (para os mais antigos "Muba"), que sem duvida me fez reavaliar muito minha postura sobre diversos aspectos do dia a dia, principalmente no que se trata de gosto musical...

Ao Professor Wendell Coltro pelo apoio. Aos amigos Thiago e Renato do BioMicS, por toda contribuição e discussão, ambos sempre se mostrando alem de ótimos profissionais excelentes amigos.

Ao amigo de todas as horas "Tião" por todos seus serviços prestados, sempre apresentando muita eficiência do desempenho de suas funções.

Ao CNPq pelo apoio financeiro.

Por fim, mas não menos importante, quero demonstrar toda minha gratidão ao Professor Marcos Teixeira ("Função"), por ter tido muita paciência em me iniciar na área cientifica, sempre com muito profissionalismo e amizade... 


\section{Resumo}

SILVA, E. R. Desenvolvimento de metodologia de baixo custo para determinação de glifosato usando microdispositivos eletroforéticos fabricados em poliéster-toner. Dissertação (Mestrado) Instituto de Química de São Carlos, Universidade de São Paulo, São Carlos, 2011.

Um grande crescimento no interesse por microdispositivos eletroforéticos tem sido observado nos últimos anos. Vantagens atrativas como baixo consumo de reagentes e diminutos tempos de analise são verificados. Microdispositivos fabricados usando toner de impressora e folhas de transparência (poliéster) vem a somar valores como baixo custo e simplicidade de confecção à técnica de micro-separação eletroforética. Entretanto, a aplicação analítica utilizando esse tipo de microdispositivo tem sido pouco explorada.

Neste trabalho o uso de microchips eletroforéticos fabricados em poliéster-toner (PT) é utilizado para a determinação simultânea do herbicida glifosato e seu maior metabólito, AMPA (ácido aminometilfosfônico). Em um primeiro momento, o trabalho apresenta o desenvolvimento de uma metodologia no qual utiliza condutometria sem contato $\left(\mathrm{C}^{4} \mathrm{D}\right)$ como sistema de detecção, aliada à separação eletroforética em microchips de PT. Vários parâmetros que regem uma boa confiabilidade analítica, tanto quanto otimizam a sensibilidade do sistema foram avaliados.

Em um segundo momento, ainda aliada à microchips de PT, a técnica de cronoamperometria foi utilizada como sistema de detecção. Nessa etapa do projeto estudos eletroquímicos foram inicialmente realizados em eletrodos convencionais de ouro e cobre, buscando averiguar qual metal apresenta maior sensibilidade para o herbicida glifosato. Tendo o metal cobre como melhor escolha, eletrodos planares foram construídos a partir da combinação das tecnologias da produção de máscaras de toner, e placas de circuito impresso como fonte de cobre.

Em ambas as metodologias desenvolvidas, picos bem resolvidos foram encontrados para os analitos em estudo. Tempos menores que $80 \mathrm{~s}$ foram gastos entre o processo de separação e detecção; uma boa repetibilidade também foi encontrada. Os valores de limite de detecção (LD) utilizando $\mathrm{C}^{4} \mathrm{D}$ foram 60,8 e $74,8 \mu \mathrm{mol} \mathrm{L}^{-1}$ para glifosato e AMPA respectivamente. Como esperado, menores valores de LD foram obtidos na detecção amperométrica, com $1,88 \mu \mathrm{mol} \mathrm{L}^{-1}$ para glifosato e $16,45 \mu \mathrm{mol} \mathrm{L}^{-1}$ para AMPA. A aplicabilidade dos métodos foi verificada através da analise do herbicida e seu metabólito em amostras de água. Etapas de derivatização e pré-concentração off-line não foram usadas nesse 
trabalho, dessa forma os dois métodos desenvolvidos apresentaram como principais vantagens o extremo baixo custo, e a simplicidade de uso.

Palavras chave: Glifosato, microchips de poliéster-toner, condutometria sem contato, cronoamperometria.

Este exemplar foi revisado e alterado em relação à versão original, sob exclusiva responsabilidade do autor.

Eduardo Rodrigues da Silva 


\begin{abstract}
SILVA, E. R. Development of low cost methodology for determination of glyphosate using electrophoretic microdevices fabricated in polyester-toner. Dissertação (Mestrado) - Instituto de Química de São Carlos, Universidade de São Paulo, São Carlos, 2011.
\end{abstract}

A large increase in interest in electrophoretic microdevices has been observed in recent years. Advantages attractive as low reagent consumption and low analytical time are checked. Microdevices fabricated using printer toner and polyester transparency sheets are the sum values as low cost and simplicity of the technique of making micro-electrophoretic separation. However, the analytical application using this type of microdevice has been little explored.

In this work the use of microchip electrophoresis fabricated on polyester-toner (PT) is used for the simultaneous determination of the herbicide glyphosate and its major metabolite, AMPA (aminomethylphosphonic acid). In a first moment, the work presents the development of a methodology in which the use capacitively coupled contactless conductivity detection $\left(C^{4} D\right)$ for determination of analytes is employed, coupled with electrophoretic separation in PT microchips. Several parameters that govern a good analytical reliability and with the intuit of optimizing the sensitivity of the system were evaluated.

In a second time and still allied to the PT microchips, the technique of chronoamperometry was used for detection. Electrochemical studies were initially conducted in conventional electrodes of gold and copper, looking for determine which metal is more sensitive to detect the herbicide glyphosate. Having the best choice planar copper electrodes were constructed from a combination of technologies for the production of toner masks, and printed circuit boards.

In both, $\mathrm{C}^{4} \mathrm{D}$ and chronoamperometric detection methodologies, well-resolved peaks were found for the glyphosate and AMPA. Time analysis of less than 80s were found including the separation and detection processes, and a good analytical repeatability was also found. The limits of detection ( $L O D)$ using $C^{4} \mathrm{D}$ were 60,8 and $74,8 \mu \mathrm{mol} \mathrm{L} \mathrm{L}^{-1}$ respectively for glyphosate and AMPA. As expected, lower LOD were obtained in the amperometric detection methodology, $1.9 \mu \mathrm{mol} \mathrm{L} \mathrm{L}^{-1}$ for glyphosate, and $16.5 \mu \mathrm{mol} \mathrm{L}^{-1}$ for AMPA. The applicability of the methods was tested by analyzing the herbicide and its metabolite in fortified water samples. Steps of derivatization and preconcentration off-line were not applied in this work, 
so the two methods showed as main advantages very low cost and time analysis, and simplicity of application.

Keywords: Glyphosate, microchip of polyester-toner, contactless conductivity, chronoamperometry, $C^{4} D$. 


\section{Lista de Figuras}

Figura 1. Diagrama esquemático do modelo de microdispositivo mais comumente usado em separações eletroforéticas. (A) Microcanais de injeção (I) e de separação (II) dispostos em cruz, com reservatórios para amostra, solução tampão, descarte da amostra e detecção por (1), (2), (3) e (4), respectivamente. (B) Intersecções entre os microcanais de injeção e separação na forma de cruz e duplo-T

Figura 2. Esquema de controle eletrocinético nos microdispositivos. (A), Configuração dos microcanais. 1, 2, 3 e 4 representam os reservatórios para amostra, tampão, descarte da amostra e descarte do tampão, respectivamente. I, II e III representam o canal de injeção, o canal de separação e o ponto de detecção. (B), (C), ilustração do preenchimento do canal de injeção. (D), separação analítica dos analitos de acordo com suas mobilidades eletroforéticas.

Figura 3. Figura representativa de um equipamento de CE convencional. Em detalhe é apresentado uma representação esquemática da migração de cátions, ânions e moléculas neutras na presença do fluxo eletrosmótico (EOF).

Figura 4. Representação esquemática da geração do fluxo eletrosmótico.

Figura 5. Perfil de fluxo típico da técnica de HPLC gerado por pressão (A), e perfil de fluxo típico da técnica de CE gerado por EOF (B).

Figura 6. Porcentagem de amostras com irregularidades analisadas por cultura. O gráfico apresenta os resultados insatisfatórios encontrados pelo PARA de 2009 para algumas culturas de alimentos.

Figura 7. Fórmula estrutural do herbicida glifosato.

Figura 8. Equilíbrios e constantes de dissociação do glifosato.

Figura 9. Principal via de degradação microbiológica do glifosato.

Figura 10. Equilíbrios e constantes de dissociação do AMPA

Figura 11. Modelo elétrico referente ao sistema de detecção $C^{4} \mathrm{D}$

Figura 12. Diagrama do sistema de detecção oscilométrica simples em microssistemas. O eletrodo de excitação e o eletrodo receptor estão representados por $\mathbf{e}_{\mathbf{e x}}$ e $\mathbf{e}_{\mathbf{r e}}$, respectivamente. As etapas (a) e (b) indicam os estágios de conversão da corrente em tensão e retificação do sinal, respectivamente.

Figura 13. Etapas do processo de microfabricação baseado na impressão direta: (I) filme de poliéster; (II) filme de poliéster com uma camada de toner (a) depositada; (III) alinhamento entre o esquema do dispositivo impresso no filme de poliéster e sua imagem especular com acesso aos reservatórios; (IV) etapa de laminação e; (V) microdispositivo finalizado com reservatórios (b) colados (tubos de PVC ou a base de ponteiras de pipetadores de $100 \mu \mathrm{L})$ 
Figura 14. Padrão de imagem utilizado para confecção dos microchips de poliéster-toner.

Figura 15. Representação do microchip fabricado em poliéster-toner com seus respectivos eletrodos para detecção $C^{4} D$. Os pontos $\mathbf{e}_{\mathbf{e x}}$ e $\mathbf{e}_{\mathbf{r e}}$ indicam os eletrodos para excitação da cela e registro do sinal resultante, respectivamente.

Figura 16. Eletroferograma obtido para uma mistura de glifosato e AMPA (ambos a 2mmol $\left.\mathrm{L}^{-1}\right)$. Condições: Tampão MES/His $\left(50 \mathrm{mmol} \mathrm{L}^{-1}\right), \mathrm{pH}$ 5,8. Injeção:-1,0kV/10 s; potencial de separação: $-1,0 \mathrm{kV}$. Frequência do sinal senoidal para detecção $\mathrm{C}^{4} \mathrm{D}: 450 \mathrm{kHz}$. Amplitude: $3,0 \mathrm{~V}_{\mathrm{pp}}$

Figura 17. Eletroferograma apresentando a separação de uma mistura contendo glifosato $(A)$ e AMPA (B), ambos a 2mmol L ${ }^{-1}$. Condições: Tampão CHES/Tris $\left(60 \mathrm{mmol} \mathrm{L}^{-1}\right), \mathrm{pH} 9,0$. Outras condições: ver Figura 16.

Figura 18. A Figura (A) apresenta um gráfico da área de pico para o glifosato em função da frequência, com uma faixa de estudo variando de 150 a $550 \mathrm{kHz}$. A Figura (B) apresenta um gráfico similar, porem com uma faixa de estudo de frequência menor (de 280 a $420 \mathrm{kHz})$.

Figura 19. Gráfico apresentando a área do pico para glifosato em função da amplitude.

Figura 20. Área do pico para glifosato e AMPA em função do pH. Condições: Tampão CHES/Tris $60 \mathrm{mmol} \mathrm{L}^{-1}$, em diferentes proporções. Condições eletroforéticas: ver Figura 16. Frequência do sinal senoidal para detecção C $\mathrm{C}^{4}$ : $320 \mathrm{kHz}$. Amplitude: $4,5 \mathrm{~V}_{\mathrm{pp}}$...................55

Figura 21. Gráfico do valor de condutividade do eletrólito de trabalho em função do $\mathrm{pH}$. 56

Figura 22. Dependência das áreas de pico para glifosato e AMPA, com a variação da concentração do eletrólito CHES/Tris. Outras condições vide Figura 20.

Figura 23. Gráfico da intensidade do sinal para glifosato em função do tempo de injeção (A). Gráfico da largura do pico para glifosato em função do tempo de injeção (B)........................58

Figura 24. Efeito do potencial de separação no tempo de migração dos analitos. .59

Figura 25. Curva obtida para a corrente eletroforética em função do potencial aplicado. Comprimento do canal: $5 \mathrm{~cm}$.....

Figura 26. Sequência de sete eletroferogramas obtidos para a separação de glifosato (a) e AMPA (b), ambos com concentração de $2 \mathrm{mmol} \mathrm{L}^{-1}$. Condições: Eletrólito CHES/Tris a 80 mmol L ${ }^{-1}$, pH 8,8. Injeção: $-1,0 \mathrm{kV} / 7$ s; potencial de separação: $-1,5 \mathrm{kV}$. Frequência do sinal senoidal para detecção $C^{4} \mathrm{D}: 320 \mathrm{kHz}$. Amplitude: 4,5 V $\mathrm{pp}$.

Figura 27. Eletroferogramas obtidos para três diferentes chips. Ambos analitos com concentração de $2 \mathrm{mmol} \mathrm{L}^{-1}$. 
Figura 28. Eletroferogramas obtidos para misturas contendo concentrações crescentes de (a) glifosato e (b) AMPA, em incrementos de $150 \mu \mathrm{mol} \mathrm{L}{ }^{-1}$. No detalhe estão apresentadas as curvas de calibração no intervalo de concentrações entre 150 e $900 \mu \mathrm{mol} \mathrm{L} \mathrm{L}^{-1}$.

Figura 29. Eletroferograma de uma amostra de água natural fortificada com glifosato e AMPA ambos a $1 \mathrm{mmol} \mathrm{L}^{-1}(i)$. Eletroferograma da amostra de água natural sem fortificação (ii ). Outras condições vide Figura 26.

Figura 30. Desenho esquemático das possíveis configurações de alinhamento do eletrodo de trabalho no microcanal de separação. (A) Eletrodo na saída do microcanal ("end-channel") e integrado no próprio dispositivo ("on-chip"), (B) eletrodo na saída do microcanal ("endchannel") e fora do dispositivo ("off-chip"), (C) eletrodo no interior do microcanal ("inchannel") e (D) eletrodo no interior do microcanal mas fora do campo elétrico da separação eletroforética ("off-channel").

Figura 31. Representação esquemática da célula eletroquímica.

Figura 32. Placa de circuito impresso com a imagem em toner já transferida (I). Placa após corrosão da camada de cobre (II). Placa após remoção do toner por acetonitrila (III). Foto digitalizada do eletrodo depois de pronto (IV), onde A trata-se da região para contato elétrico e $\mathbf{B}$ da área geométrica ativa do eletrodo.

Figura 33. Voltamogramas na presença $\left(5,0 \mathrm{mmol} \mathrm{L}^{-1}\right)$ e ausência de glifosato, em solução de $\mathrm{NaOH} 0,1 \mathrm{~mol} \mathrm{~L}^{-1}$; usando eletrodo de ouro ( $1 \mathrm{~mm}$ de diâmetro). Velocidade de varredura 100 $\mathrm{mV} \mathrm{s}^{-1}$ (A). Resposta eletroquímica para diferentes concentrações de glifosato em eletrodo de ouro (B).

Figura 34. Voltamogramas cíclicos do eletrodo de cobre em $0,1 \mathrm{~mol} \mathrm{~L}^{-1}$ de tampão fosfato na ausência e na presença de $1,0 \mathrm{mmol} \mathrm{L}{ }^{-1}$ de glifosato. Velocidade de varredura $100 \mathrm{mV} \mathrm{s}^{-1}$ (A). Resposta eletroquímica para diferentes concentrações de glifosato em eletrodo de cobre (B). Eletrodo de cobre com $1 \mathrm{~mm}$ de diâmetro.

Figura 35. Comparação da resposta eletroquímica do glifosato em eletrodo de cobre e ouro.

Figura 36. Desenho esquemático do sistema usado para o acoplamento entre eletroforese em microdispositivos e detecção eletroquímica. (A) Partes do sistema: (a) suporte em acrílico com posicionador $x-y$, (b) microdispositivo fabricado em PT e (c) eletrodo de cobre fabricado a partir de placas de circuito impresso. (B) Acoplamento do microdispositivo e do eletrodo de trabalho no suporte.

Figura 37. Voltamograma cíclico do eletrodo de cobre confeccionado a partir de placas de circuito impresso em $0,1 \mathrm{~mol} \mathrm{~L}^{-1}$ de $\mathrm{NaOH}\left(\mathrm{pH} \mathrm{13,0).} \mathrm{Velocidade} \mathrm{de} \mathrm{varredura} 100 \mathrm{mV} \mathrm{s}^{-1} .86\right.$

Figura 38. Eletroferograma de uma mistura contendo $100 \mu \mathrm{mol} \mathrm{L}^{-1}$ de glifosato (A) e 500 $\mu \mathrm{mol} \mathrm{L}{ }^{-1}$ de AMPA (B). Condições: Tampão fosfato $10 \mathrm{mmol} \mathrm{L}^{-1}, \mathrm{pH} 7,5$. Injeção:-1,0 kV/10 s; potencial de separação: $-1,0 \mathrm{kV}$. Potencial do eletrodo de trabalho: $0,1 \mathrm{~V}$.

Figura 39. Variação da área do pico para glifosato e AMPA, em função do potencial aplicado no eletrodo de trabalho. Outras condições ver Figura 38. 
Figura 40. Área do pico para glifosato e AMPA em função do pH. Condições: Tampão

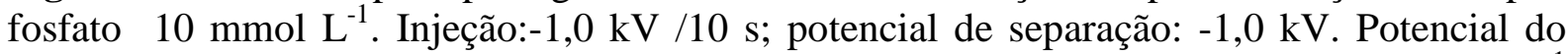
eletrodo de trabalho: $0,15 \mathrm{~V}$. Concentração de glifosato e AMPA a 100 e $500 \mu \mathrm{mol} \mathrm{L}^{-1}$

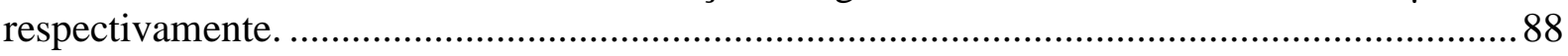

Figura 41. Diagrama de distribuição de espécies em função do $\mathrm{pH}$ para glifosato (A) e

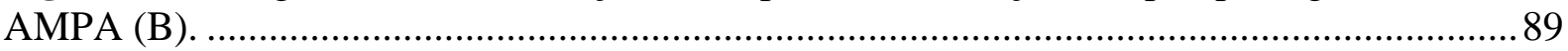

Figura 42. Dependência das áreas de pico para glifosato e AMPA com a variação da concentração do tampão fosfato. .................................................................................... 90

Figura 43. Gráfico da intensidade do sinal para glifosato em função do tempo de

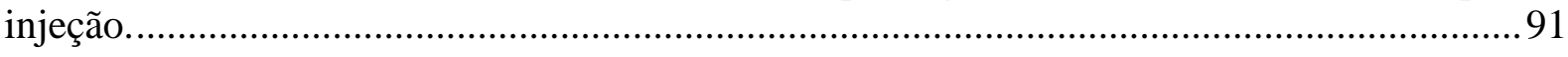

Figura 44. Gráfico da largura do pico para glifosato em função do tempo de injeção. .......... 92

Figura 45. Curva obtida para a corrente eletroforética em função do potencial aplicado.......92

Figura 46. Sequência de seis eletroferogramas obtidos para a separação de glifosato (a) com concentração de $100 \mu \mathrm{mol} \mathrm{L}{ }^{-1}$ e AMPA (b) a $500 \mu$ mol L ${ }^{-1}$. Condições: Tampão fosfato 5 mM, pH 6,4. Injeção:-1,0 kV/14 s; potencial de separação: $-1,7$ kV. Potencial do eletrodo de trabalho: $0,15 \mathrm{~V}$.

Figura 47. Curvas analíticas para glifosato (A) e AMPA (B), obtidas utilizando detecção amperométrica em eletrodo de cobre confeccionado a partir de placas de circuito impresso, aliada a separação eletroforética em microchips de PT. Outras condições ver Figura 46. ......94

Figura 48. Eletroferograma de uma amostra de água potável fortificada com $100 \mu \mathrm{mol} \mathrm{L} \mathrm{L}^{-1}$ de glifosato e $500 \mu \mathrm{mol} \mathrm{L}{ }^{-1}$ de AMPA (linha cheia). Na linha tracejada é apresentado o eletroferograma da amostra sem fortificação. .96 


\section{Lista de Tabelas}

Tabela 1. Propriedades físico-químicas do herbicida glifosato.

Tabela 2. Constantes de estabilidade $(\log \mathrm{K})$ de complexos metálicos com glifosato. 33

Tabela 3. Manifestações clínicas agudas do glifosato por sistema. 34

Tabela 4. Limite máximo de resíduo de glifosato em alguns alimentos. 35

Tabela 5. Procedência e pureza dos reagentes utilizados. 42

Tabela 6. Valores críticos de $Q$ para um teste bi-caudal, com limite de confiança de $95 \%$.

Tabela 7. Comparação dos parâmetros da regressão linear, obtidos na variação de concentração de glifosato em eletrodo de ouro e cobre. Numero de pontos $=7$. 84 


\section{Lista de Abreviaturas e Símbolos}

\begin{tabular}{|c|c|c|}
\hline$\mu_{a p}$ & - & mobilidade aparente \\
\hline$\mu_{e f}$ & - & mobilidade efetiva \\
\hline$\mu_{e o f}$ & - & mobilidade do fluxo eletrosmótico \\
\hline$\mu \mathrm{TAS}$ & - & Micro-Sistemas para análises totais \\
\hline AMPA & - & ácido aminometilfosfônico \\
\hline ANVISA & - & Agência Nacional de Vigilância Sanitária \\
\hline $\mathrm{b}$ & - & coeficiente angular da curva \\
\hline BGE & - & eletrólito de trabalho \\
\hline BioMicS & - & Grupo de Bioanalítica, Microfabricação e Separações \\
\hline$C$ & - & Capacitância \\
\hline$C^{4} \mathrm{D}$ & - & condutometria sem contato capacitivamente acoplada \\
\hline $\mathrm{CE}$ & - & Eletroforese capilar \\
\hline CONAMA & - & Conselho Nacional de Meio Ambiente \\
\hline $\mathrm{CV}$ & - & coeficientes de variação \\
\hline CZE & - & eletroforese capilar de zona \\
\hline DO & - & detecção oscilométrica \\
\hline $\mathrm{E}$ & - & campo elétrico \\
\hline $\mathrm{e}_{\mathrm{ex}}$ & - & eletrodo de excitação \\
\hline EOF & - & fluxo eletrosmótico \\
\hline $\mathrm{e}_{\mathrm{re}}$ & - & eletrodo receptor \\
\hline FMOC & - & 9-fluorenilmetilcloroformato \\
\hline GM & - & geneticamente modificada \\
\hline GMEME & - & Grupo de Materiais Eletroquímicos e Métodos Eletroanalíticos \\
\hline HPLC & - & Cromatografia líquida de alta eficiência \\
\hline LD & _- & limite de detecção \\
\hline
\end{tabular}




\begin{tabular}{|c|c|c|}
\hline LIF & - & fluorescência induzida a laser \\
\hline LMR & - & Limite Máximo de Resíduo \\
\hline$N$ & - & número de pratos teóricos \\
\hline NDA & - & naftaleno-2,3-dicarboxialdeído \\
\hline OPA & - & o-ftalaldeído \\
\hline PAD & - & amperometria pulsada \\
\hline PARA & - & Programa de Análise de Resíduos de Agrotóxicos em Alimentos \\
\hline PT & - & poliéster-toner \\
\hline$R$ & - & Resolução \\
\hline RSD & - & desvio padrão relativo \\
\hline $\mathrm{SD}$ & - & desvio padrão do intercepto da curva \\
\hline SPE & - & extração em fase sólida \\
\hline SPME & - & Microextração em fase sólida \\
\hline SPME & - & microextração em fase sólida \\
\hline$t_{m i g}$ & - & tempo de migração \\
\hline $\mathrm{v}_{E O F}$ & - & velocidade do fluxo eletrosmótico \\
\hline$v_{\mathrm{EP}}$ & - & velocidade de migração eletroforética \\
\hline $\mathrm{w}_{1 / 2}$ & - & Largura do pico a meia altura \\
\hline $\mathrm{X}_{\mathrm{c}}$ & - & Impedância \\
\hline$\varepsilon$ & - & constante dielétrica do tampão \\
\hline$\zeta$ & - & Potencial zeta \\
\hline$\eta$ & - & viscosidade do tampão \\
\hline
\end{tabular}




\section{Sumário}

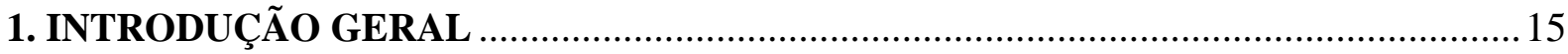

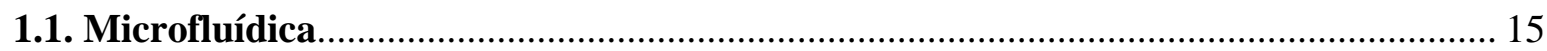

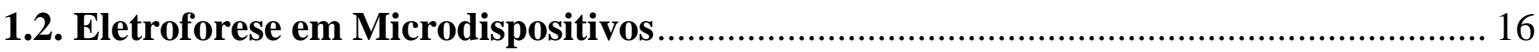

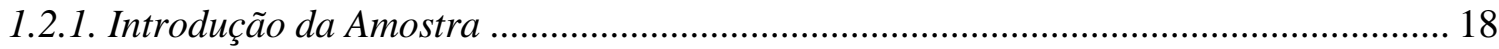

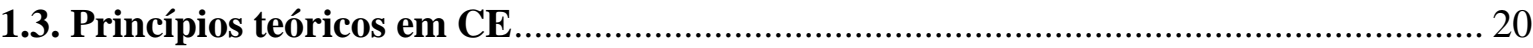

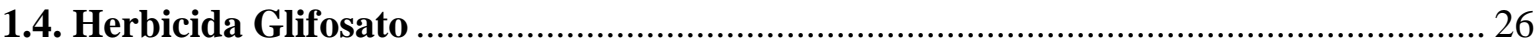

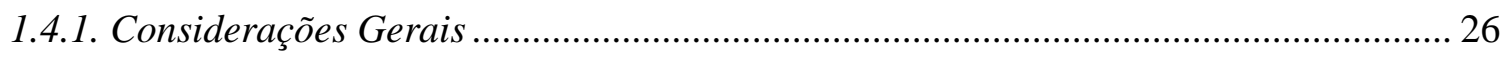

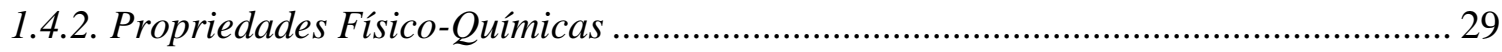

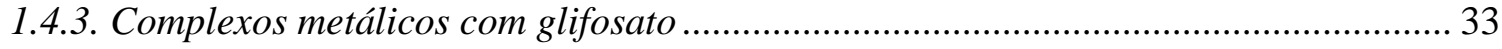

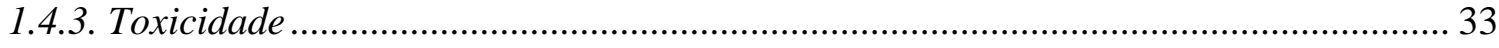

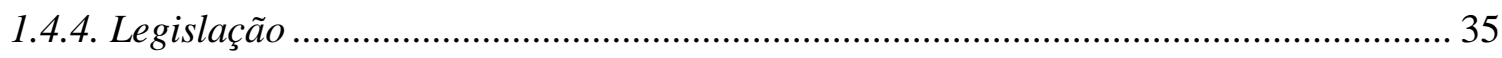

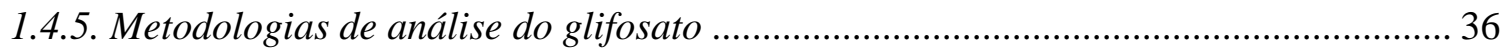

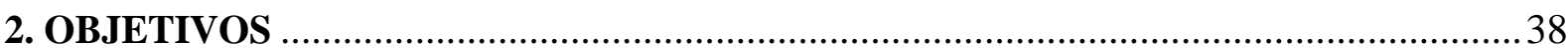

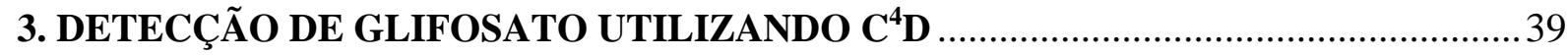

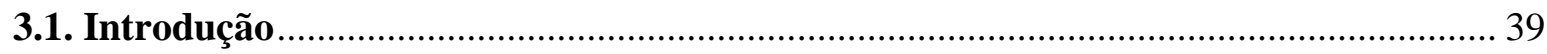

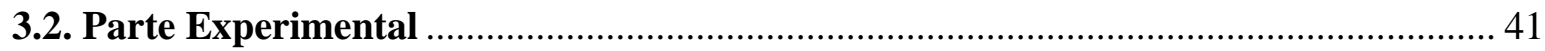

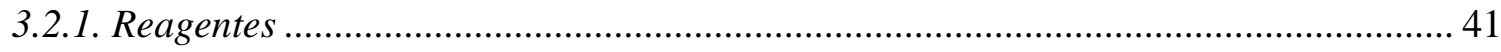

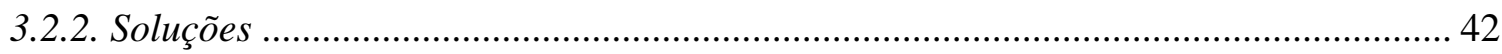

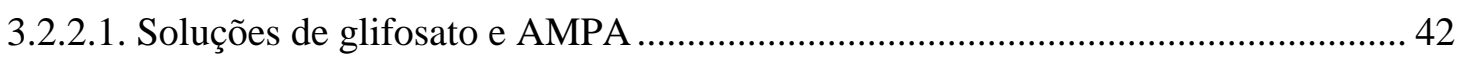

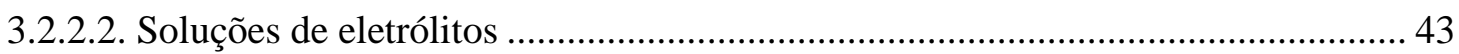

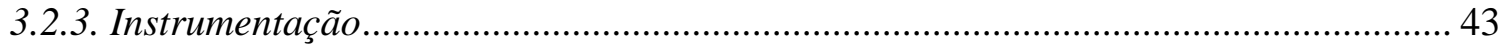

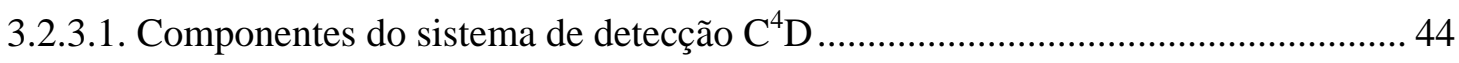

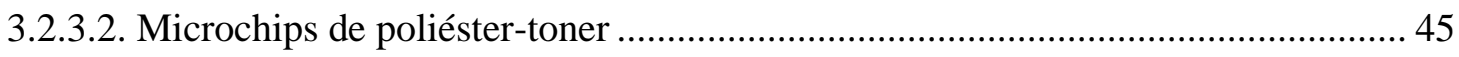

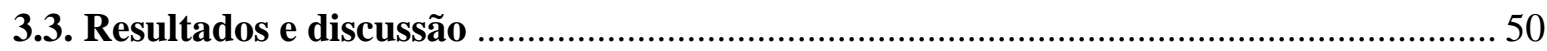

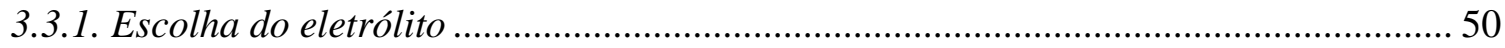


3.3.2. Estudo da frequência e amplitude.

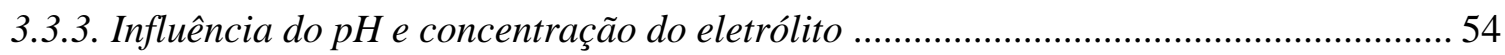

3.3.5. Determinação do Tempo de Injeção da Amostra ........................................................... 57

3.3.6. Influência do potencial de separação e gráfico de Ohm .............................................. 59

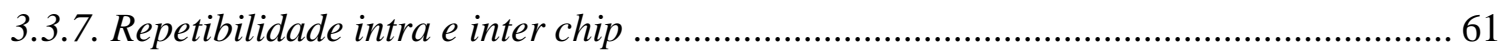

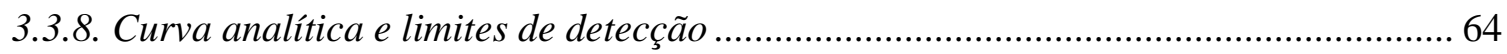

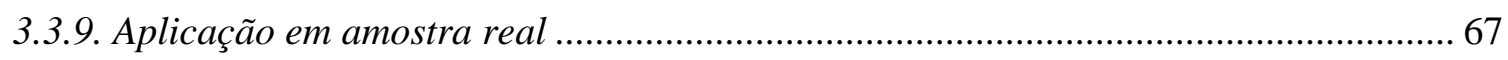

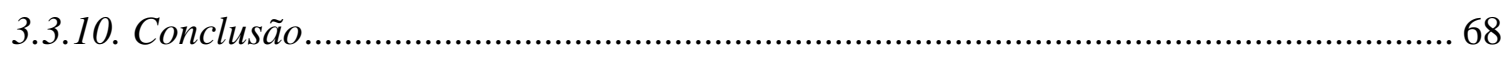

4. DETECÇÃO DE GLIFOSATO POR CRONOAMPEROMETRIA ............................... 70

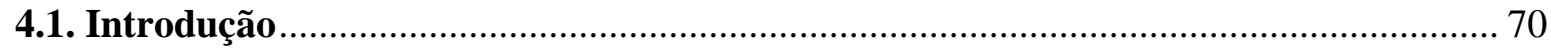

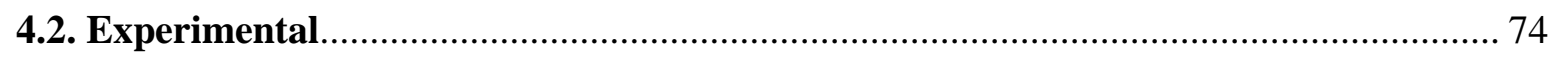

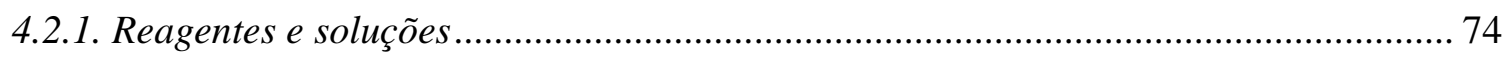

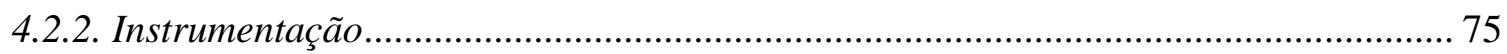

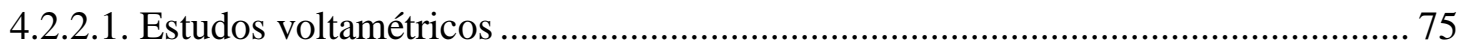

4.2.2.2. Confecção do eletrodo planar de cobre ............................................................... 76

4.2.2.3. Sistema de detecção amperométrica .................................................................. 77

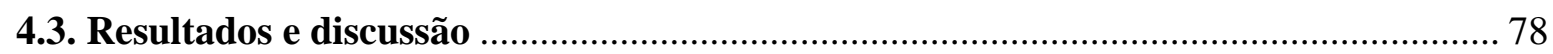

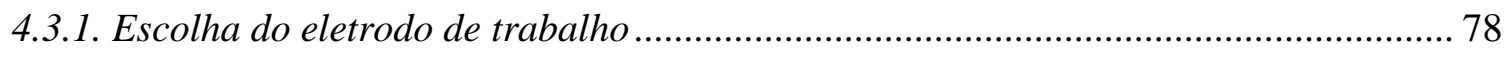

4.3.2. Acoplamento do sistema eletroforético à detecção eletroquímica............................... 85

4.3.3. Otimização do potencial de detecção eletroquímico ................................................. 87

4.3.4. Influência do pH e concentração do tampão fosfato ................................................... 88

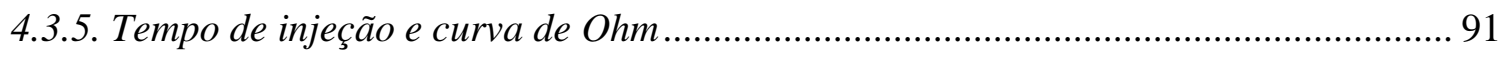

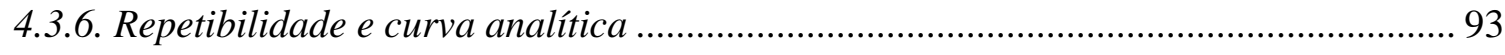

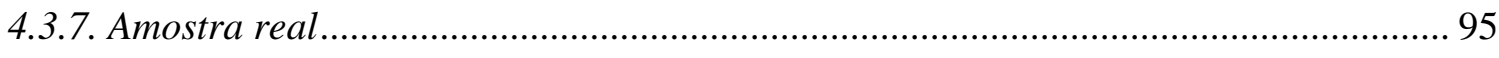

4.3.8. Conclusão

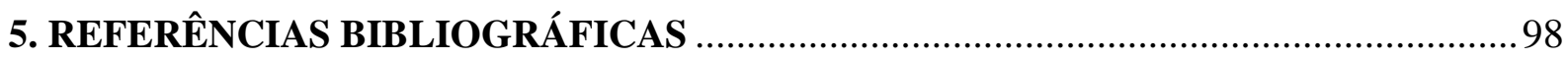




\section{INTRODUÇÃO GERAL}

\subsection{Microfluídica}

A Microfluídica é a Ciência e Tecnologia de Sistemas que processa ou manipula pequenas quantidades de fluidos, usando canais com dimensões entre dezenas e centenas de micrometros $^{1}$. Os sistemas microfluídicos operam com volumes na ordem de $10^{-9}$ a $10^{-12}$ litros. As principais aplicações de tecnologias desenvolvidas em microfluídica estão concentradas em química analítica, onde podem oferecer um grande número de capacidades, como a habilidade de manipular quantidades muito pequenas de amostras e reagentes, conduzir separações e detecções com grandes resoluções e sensibilidades, baixo custo, altas frequências analíticas e portabilidade.

O início do desenvolvimento da microfluídica ocorreu em 1979 com construção do primeiro sistema analítico miniaturizado: um cromatógrafo a gás de pequenas dimensões ${ }^{2}$. Desenvolvido com a integração do injetor, coluna cromatográfica e detector, em uma placa circular de silício de apenas $5 \mathrm{~cm}$ de diâmetro, o dispositivo foi usado com sucesso na separação dos componentes de uma mistura de hidrocarbonetos. Entretanto, apesar da capacidade de realizar rápidas separações, esse primeiro microdispositivo não teve repercussão significativa na comunidade científica, dessa forma os trabalhos produzidos na década de 80, relacionados à miniaturização, ficaram voltados apenas ao desenvolvimento de sensores químicos, micro-bombas e micro-válvulas ${ }^{3}$.

Microreservatórios, microcanais, microbombas e microválvulas são elementos que constituem os sistemas microfluídicos e que agrupados podem ser utilizados como filtros; microreatores; separadores ou misturadores de substâncias; sensores, entre outras funções. Em 
muitos exemplos da literatura, há sistemas de microanálise que realizam processamento paralelo de diversas substâncias com grande eficiência, realizando diversas das funções descritas simultaneamente, gerando novos termos na ciência como Lab-on-a-Chip, literalmente laboratório em um Chip, e o $\mu$ TAS, traduzidos como sistemas de análise total. O termo microfabricação também é usado, e está relacionado à fabricação de estruturas micrométricas em substratos sólidos como polímeros, vidros, silicatos, etc. Os métodos de microfabricação incluem fotolitografia, corrosão química via úmida, deposição de filmes (plasma, sputtering, etc.), moldagem, vedação, etc ${ }^{4}$. Dentro da escala miniaturizada, uma grande atenção tem sido dada por diversos pesquisadores no desenvolvimento de microdispositivos confeccionados para fins eletroforéticos.

\subsection{Eletroforese em Microdispositivos}

Entre as técnicas analíticas de separação, a eletroforese capilar (CE) é a principal técnica desenvolvida em microdispositivos devido à simplicidade de sua instrumentação. $\mathrm{O}$ controle eletrocinético dos fluidos, que requer somente eletrodos para aplicação de campo elétrico, elimina a necessidade do uso de válvulas e bombas que são de difícil construção e interface com sistemas miniaturizados ${ }^{5}$.

A eletroforese capilar é uma das mais recentes técnicas analíticas de separação, sendo que a introdução do primeiro equipamento comercial data de aproximadamente 20 anos. No início da década de 80 , a CE surgiu como uma alternativa à cromatografia líquida de alta eficiência (HPLC), que ainda hoje é uma das técnicas mais utilizadas em análises qualitativas e quantitativas dos mais diversos compostos. Apesar de uma relativa demora da introdução da CE no mercado, possivelmente pela prevalência de outras técnicas analíticas mais 
consolidadas, as companhias e institutos de pesquisa continuaram aperfeiçoando os equipamentos e criando as mais variadas condições de separação em CE.

A CE é considerada uma ferramenta muito poderosa de análise, pois conta com baixo custo operacional, possui alta resolução e ainda tem reduzido volume de descartes. O consumo de amostras geralmente é da ordem de microlitros e a de reagentes, de mililitros, o que torna o equipamento econômico e pouco poluidor. Esta técnica é reconhecidamente versátil, e vem sendo utilizada com sucesso para a separação e quantificação dos mais variados tipos de compostos, sejam pequenos íons, moléculas neutras e até mesmo grandes biomoléculas. A técnica já comprovou ser extremamente eficiente na análise das mais variadas moléculas em áreas como por exemplo, a química analítica, forense, orgânica, análises clínicas, de produtos naturais, na indústria farmacêutica e da biologia molecular ${ }^{6-13}$.

A Figura 1 apresenta o diagrama esquemático do modelo de microdispositivo mais comumente usado em separações eletroforéticas. Como observado, trata-se de um microdispositivo com microcanais de injeção (I) e de separação (II) dispostos em cruz. Nas extremidades do microcanal de injeção há reservatórios para amostra (1) e descarte da amostra (3), enquanto que o microcanal de separação está delimitado pelos reservatórios da solução tampão (2) e de detecção (4).

Algumas estratégias podem ser utilizadas para aumentar o volume de amostras injetada, e consequentemente conseguir um ganho de sensibilidade. Com a variação do formato geométrico dos canais, o aumento de amostra injetada pode ser alcançado. Uma configuração de duplo-T (Figura 1), por exemplo, pode ser utilizada para esse fim; nesse caso o volume total injetado está relacionado com o comprimento total desse duplo-T. 


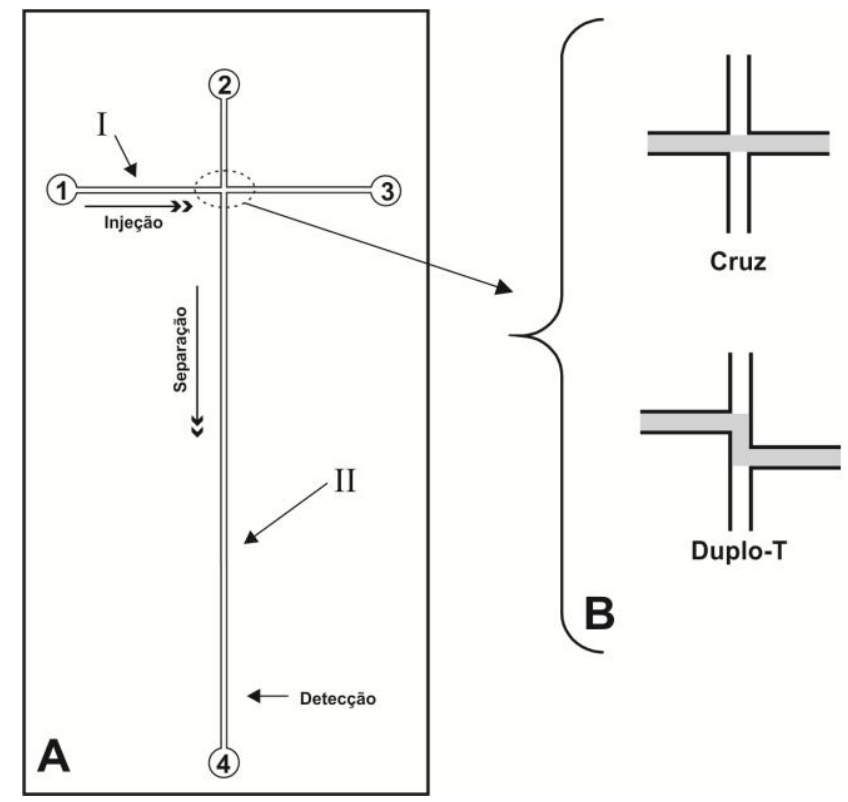

Figura 1. Diagrama esquemático do modelo de microdispositivo mais comumente usado em separações eletroforéticas. (A) Microcanais de injeção (I) e de separação (II) dispostos em cruz, com reservatórios para amostra, solução tampão, descarte da amostra e detecção por (1), (2), (3) e (4), respectivamente. (B) Intersecções entre os microcanais de injeção e separação na forma de cruz e duplo-T.

\subsubsection{Introdução da Amostra}

Dois principais métodos de injeção de amostra são encontrados em eletroforese capilar convencional, injeção eletrocinética e injeção hidrodinâmica. Dos dois métodos, a injeção eletrocinética é majoritariamente utilizada em microdispositivos. Na injeção eletrocinética apenas as espécies que apresentam carga sob as condições do experimento poderão ser injetadas. A importância da introdução de amostra deve-se ao fato de que as características da zona de amostra (definida pela intersecção dos canais) determinam a qualidade da separação analítica. Além disso, para um estudo quantitativo há a necessidade de uma boa repetibilidade das injeções ${ }^{14}$. A equação 1 descreve a quantidade de material injetado $(n)$ para dentro de um canal $^{15}$.

$$
n=\mu_{a p}\left(E \frac{K_{t}}{K_{a m}}\right) A C t
$$


Nessa equação, $n$ é o número de moles injetado de uma espécie para dentro do canal, $\mu_{a p}$ é a mobilidade aparente da espécie a ser injetada (soma da mobilidade efetiva $\mu_{e f}$ com a mobilidade do fluxo eletrosmótico $\mu_{e o f}$ ), $A$ é a área da secção do canal, $C$ é a concentração da espécie e $t$ é o tempo de injeção. O termo entre parênteses é chamado de campo elétrico efetivo, dado pelo vetor campo elétrico $E$ e a razão das condutividades entre o tampão $K_{t}$ e a $\operatorname{amostra} K_{a m}$.

Existem basicamente três modos de injeção eletrocinética em microdispositivos: "unpinched" 16 , "pinched"17 e "gated"18. Entre eles, o mais simples e comum é o modo "unpinched", onde a zona da amostra é determinada basicamente pela geometria dos microcanais que pode ser na forma de cruz. Para melhor compreensão, a Figura 2 apresenta o esquema do controle eletrocinético nos microcanais. Para realizar a injeção uma diferença de potencial é aplicada no canal de injeção durante 1-10 s, pelos eletrodos posicionados nos reservatórios da amostra (1) e de descarte da amostra (3) (Figura 2B). Neste curto período de tempo, a tendência é que o microcanal de injeção fique completamente preenchido com a amostra (Figura 2C). Após completar o preenchimento do microcanal de injeção, a etapa de separação é iniciada pela aplicação de uma diferença de potencial no canal de separação nos eletrodos posicionados nos reservatórios do tampão (2) e de descarte do tampão (4), também denominado de reservatório de detecção. Deste modo, a zona de amostra definida pela intersecção dos canais (volume de amostra injetada = volume da intersecção dos canais) é transportada na direção do detector (Figura 2D) e as espécies são separadas de acordo com suas mobilidades eletroforéticas. 
(A)

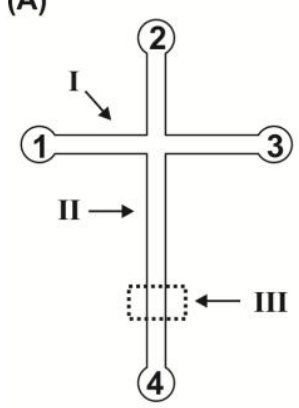

(C)

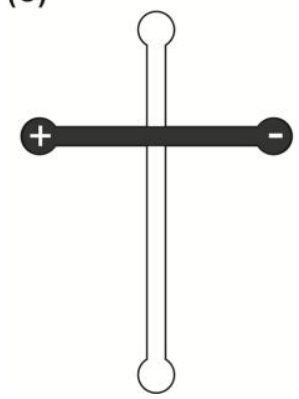

(B)

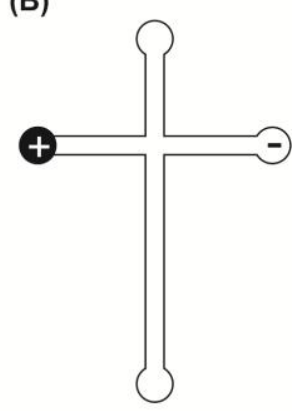

(D)

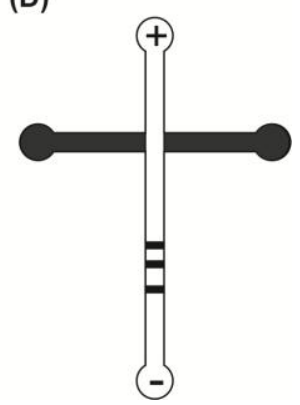

Figura 2. Esquema de controle eletrocinético nos microdispositivos. (A), Configuração dos microcanais. 1, 2, 3 e 4 representam os reservatórios para amostra, tampão, descarte da amostra e descarte do tampão, respectivamente. I, II e III representam o canal de injeção, o canal de separação e o ponto de detecção. (B), (C), ilustração do preenchimento do canal de injeção. (D), separação analítica dos analitos de acordo com suas mobilidades eletroforéticas.

As teorias discutidas a seguir, relacionadas à CE, são válidas também para eletroforese em microescala. Porém, enquanto em CE a separação ocorre em um capilar no formato micro, a separação em microdispositivos ocorre em microcanais os quais podem ser fabricados nos mais diferentes tipos de materiais.

\subsection{Princípios teóricos em CE}

Eletroforese é uma técnica de separação baseada na migração diferenciada de compostos iônicos ou ionizáveis sob a influência de um campo elétrico. Diferentes partículas com cargas e/ou tamanhos variados migram com velocidades distintas: este é o princípio 
básico de todos os métodos eletroforéticos de separação ${ }^{19}$. Uma representação esquemática de um sistema de CE convencional pode ser visualizada na Figura 3.

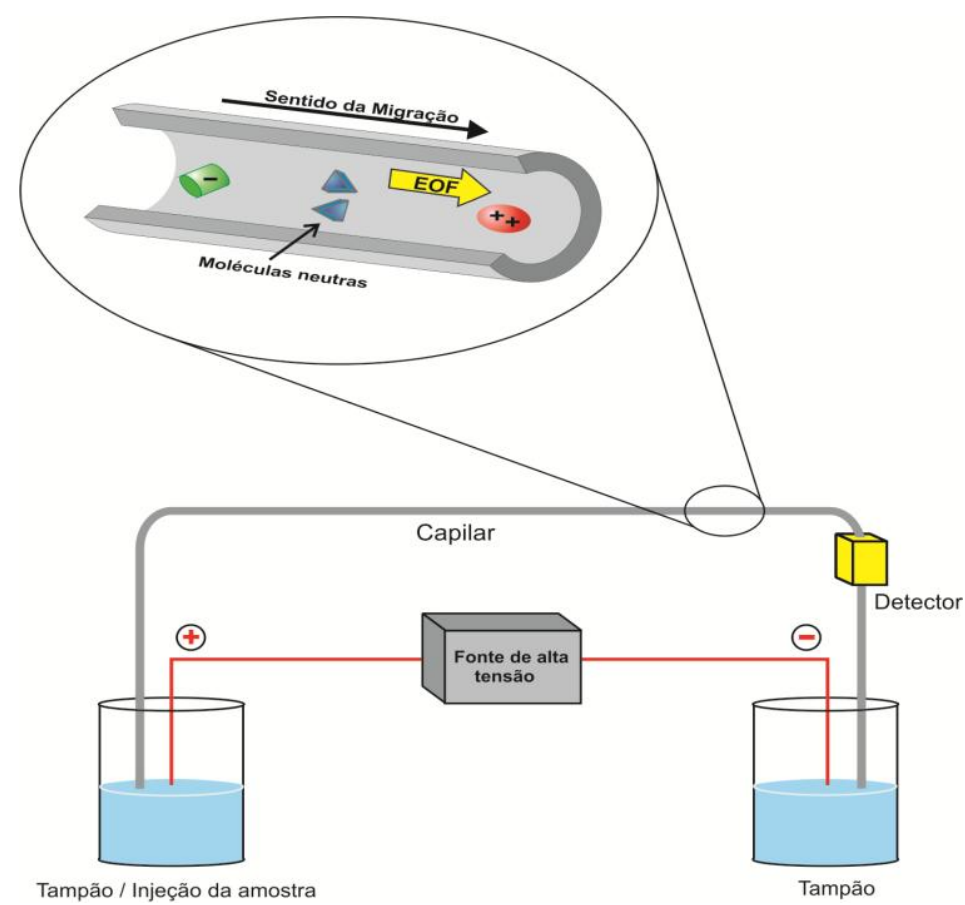

Figura 3. Figura representativa de um equipamento de CE convencional. Em detalhe é apresentado uma representação esquemática da migração de cátions, ânions e moléculas neutras na presença do fluxo eletrosmótico (EOF).

Como se pode observar na Figura 3, um equipamento de $\mathrm{CE}$ consiste de dois reservatórios conectados por um tubo capilar e preenchidos por um mesmo eletrólito. Esses reservatórios possuem eletrodos metálicos (geralmente de platina) onde é aplicada uma diferença de potencial (tipicamente variando de 10 a $30 \mathrm{kV}$ ). O campo elétrico formado promove a migração das espécies que são injetadas em uma das extremidades do capilar. O fato de o capilar possuir um diâmetro interno bastante reduzido (tipicamente 20 a $100 \mu \mathrm{m}$ ) possibilita uma dissipação eficiente do calor gerado pela passagem da corrente elétrica (efeito Joule). Os analitos injetados migram no interior do capilar e são detectados através de um detector que é disposto na extremidade oposta à da injeção. 
O registro gráfico de uma análise eletroforética é denominado eletroferograma, onde é apresentado o sinal dos analitos que passaram pela zona de detecção em função do tempo decorrido. A partir de parâmetros obtidos do eletroferograma, é possível retirar informações a cerca da qualidade de separação. Uma medida quantitativa da resolução entre dois picos é dada pela Equação 2. O número de pratos teóricos $(N)$, calculado a partir da Equação 3, demonstra a eficiência da separação.

$$
\begin{gathered}
R=\frac{2\left(t_{m 2}-t_{m 1}\right)}{\left(w_{1}+w_{2}\right)} \\
N=16\left(\frac{t_{m}}{w}\right)^{2}=5,54\left(\frac{t_{m}}{w_{1 / 2}}\right)^{2}
\end{gathered}
$$

Em CE, além dos solutos, a solução tampão também move-se através do capilar sob a influência do campo elétrico gerando o fluxo eletrosmótico ( discutido em detalhes a seguir). A presença do fluxo eletrosmótico torna possível analisar cátions, ânions e moléculas neutras na mesma corrida pois promove a condução dos solutos, sem distinção de carga, na direção do detector $^{20}$ (apresentado no detalhe da Figura 3).

A CE pode ser classificada de acordo com seu modo de operação. A eletroforese capilar de zona (CZE) é o modo mais comum de operação em CE. Trata-se de um método de separação em solução que ocorre como resultado de duas estratégias: maximizar as diferenças entre as mobilidades eletroforéticas efetivas dos analitos e minimizar as causas de alargamento das zonas. A mobilidade eletroforética prediz que sob influência de um campo elétrico, uma espécie eletricamente carregada irá migrar através do capilar em direção ao polo de carga oposta. A velocidade de migração eletroforética $\left(v_{\mathrm{EP}}\right)$ é determinada pela seguinte equação: 


$$
V_{E P}=\mu_{E P} E=\frac{q}{6 \pi \eta r} E
$$

Onde:

$\mu_{E P}=$ mobilidade eletroforética da espécie

$E$ = campo elétrico aplicado

$q$ = carga do íon

$\eta=$ viscosidade do meio

$r=$ raio do íon solvatado

Como comentado, a presença do fluxo eletrosmótico torna possível a analise de cátions, anions e moléculas neutras em uma mesma corrida. Este fluxo origina-se da ionização dos grupos silanóis (Figura 4) da superfície interna do capilar de sílica fundida ${ }^{21}$. Em pH acima de 3, ocorre a dissociação dos grupos silanóis superficiais ( $\mathrm{Si}-\mathrm{OH})$ que constituem a parede interna do capilar de sílica, conferindo à superfície interna um caráter negativo. Com isso, os cátions do eletrólito que preenchem o capilar tendem a se aproximar da parede e, sob um campo elétrico, são atraídos para o cátodo. Como estes estão solvatados arrastam o solvente, proporcionando o "bombeamento" de solução no interior do capilar. Desta forma, a movimentação dos íons dentro do capilar passa a depender não somente da sua própria mobilidade, mas também da mobilidade do EOF, que consequentemente dependerá da composição do eletrólito utilizado.

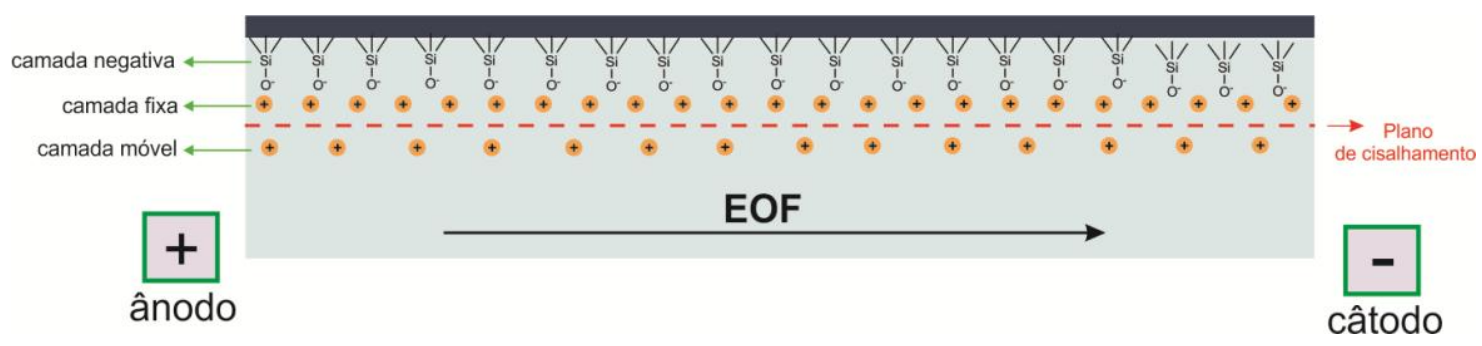

Figura 4. Representação esquemática da geração do fluxo eletrosmótico. 
A velocidade do $\mathrm{EOF}\left(\mathrm{v}_{E O F}\right)$ pode ser determinada pela Equação 5.

$$
v_{E O F}=\mu_{E O F} E
$$

A mobilidade eletrosmótica, $\left(\mu_{E O F}\right)$ por sua vez pode ser calculada a partir da Equação 6

$$
\mu_{E O F}=\frac{\varepsilon \zeta}{4 \pi \eta}
$$

onde:

$\varepsilon=$ constante dielétrica do tampão

$\zeta=$ potencial zeta

$\eta=$ viscosidade do tampão

É possível observar na equação 6 que a mobilidade eletrosmótica é dependente da superfície do capilar (potencial zeta), das características do tampão como a constante dielétrica, a viscosidade, o pH e a concentração; e é independente do campo elétrico aplicado.

O EOF é diferente para cada tipo de capilar ou de canal utilizado. A magnitude do EOF pode ser determinada pela injeção e detecção de um composto neutro, adicionado à amostra ou injetado individualmente. Com a medida do tempo de migração $\left(t_{m i g}\right)$ e, conhecendo o comprimento efetivo ( $l$ ) (comprimento do capilar até o ponto de detecção) pode-se calcular a velocidade eletrosmótica, $v_{E O F}$, em $\mathrm{cm} \mathrm{s}^{-1}$ como representado na Equação 7:

$$
v_{E O F}=\frac{l}{t_{m i g}}
$$


Combinando as equações 5 e 7, a mobilidade eletrosmótica, $\mu_{E O F}$, dada em $\mathrm{cm}^{2} \mathrm{~V}^{-1} \mathrm{~s}^{-1}$, pode ser calculada pela divisão da velocidade eletrosmótica, em $\mathrm{cm} \mathrm{s}^{-1}$, pelo campo elétrico, $\mathrm{E}, \mathrm{em} \mathrm{V} \mathrm{cm}^{-1}$.

Quando os parâmetros do EOF são medidos usando um marcador neutro, é importante que o marcador seja escolhido de modo a se mover ao longo do capilar sob a ação exclusiva do EOF. O principal critério na escolha de um marcador é que ele seja neutro no $\mathrm{pH}$ do tampão, detectável no detector utilizado, puro e que não tenha interação com a parede do capilar ou do canal, e também deve ser solúvel no tampão.

O EOF é caracterizado por um perfil planar de velocidade não contribuindo para o alargamento das bandas (Figura 5). Esse fato distingue a CE dos métodos cromatográficos em fase líquida (colunas não empacotadas) que apresentam perfil parabólico de velocidade dentro da coluna, característico do fluxo induzido por pressão. Essa característica permite que se obtenha picos ainda mais estreitos e definidos.

A

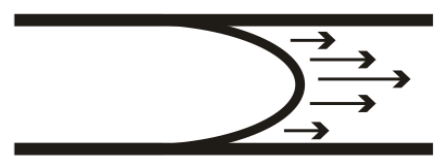

B

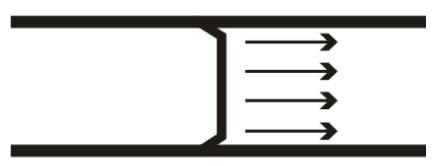

Figura 5. Perfil de fluxo típico da técnica de HPLC gerado por pressão (A), e perfil de fluxo típico da técnica de CE gerado por EOF (B).

Quando uma espécie química eletricamente carregada é injetada, o tempo que ela levará para chegar até o detector (velocidade aparente) é representado pela velocidade efetiva (velocidade do íon) somada à velocidade do EOF. Em condições normais (polaridade normal), o EOF ocorre do ânodo (pólo positivo) para o cátodo (pólo negativo). No entanto, quando desejado, o EOF pode ser reduzido, suprimido ou mesmo ter o sentido invertido. A redução e/ou supressão do EOF no capilar é, na maioria dos casos, aplicada com o objetivo de 
reduzir a mobilidade aparente das espécies no interior do capilar, favorecendo, desta forma, a separação de espécies de mobilidades muito próximas. A redução ou supressão do fluxo também pode ser conseguidas com a diminuição do $\mathrm{pH}(\leq 3,0)$, a adição de solventes orgânicos, ou aditivos para recobrir a parede interna do capilar, tais como, tensoativos catiônicos, álcool polivinílico, polímeros de celulose entre outros. A escolha adequada do tensoativo, assim como de sua concentração, permite o controle direto da magnitude do EOF e mesmo a sua inversão ${ }^{22}$. A inversão do EOF com a utilização de tensoativos catiônicos como o CTAB (brometo de cetiltrimetilamônio) é bastante comum e útil, especialmente na análise de ânions.

\subsection{Herbicida Glifosato}

\subsubsection{Considerações Gerais}

Pesticida é qualquer substância (ou mistura de substâncias) natural ou sintética, usada para controlar ou repelir qualquer praga de origem animal ou vegetal, que de alguma forma compete com o bem estar humano ${ }^{23}$. No geral são substancias químicas; podendo ainda existir na forma de agentes biológicos como vírus ou bactérias. Varias denominações são atribuídas a esses tipos de compostos: agrotóxicos, defensivos químicos, praguicidas, fitossanitários, agroquímicos, etc. Porém mesmo com a contradição de termos, o mais utilizado internacionalmente vem a ser "pesticidas", e assim sendo, será utilizado no decorrer deste documento.

Em relação ao organismo alvo, os pesticidas são classificados em inseticidas, fungicidas, herbicidas, acaricidas, entre outros. Dentre essas diferentes classes os herbicidas 
se destacam pelo elevado consumo mundial, onde seu uso é empregado no combate de pragas, doenças ou eliminação de plantas daninhas. $\mathrm{O}$ uso de herbicidas na área agrícola tem como objetivo atingir altos índices de produtividade, e conseguir desta forma suprir a necessidade alimentar da população mundial.

Apesar dos benefícios no controle e/ou combate às pragas que evitam a queda na produção de alimentos, os pesticidas são apontados como poluentes ambientais ${ }^{24}$. Em muitos estudos sobre a relação percentual entre a quantidade total aplicada de um pesticida e aquela que alcança seus objetivos como controle de pragas, se estima que aproximadamente $0,3 \%$ atingem sua substância alvo, e os 99,7\% restantes se dissipam no meio ambiente podendo até chegar a contato humano ${ }^{25}$.

Grande atenção tem sido empregada por pesquisadores, órgãos governamentais reguladores e pela própria opinião pública ao impacto dos pesticidas sobre a saúde humana e ao ambiente. Como consequência, varias restrições no uso desses produtos foram impostas a nível nacional e internacional. Com o objetivo de controlar o uso adequado de pesticidas no campo, o Brasil criou uma legislação especifica para esse fim com a Lei n. 7.802 de 11 de julho de 1989.

Atualmente o Brasil é o maior consumidor de pesticidas do mundo, gerando em 2009 uma receita de US\$ 7 bilhões e um consumo de 700 mil toneladas de pesticidas ${ }^{26}$. Com base no alto consumo desses produtos no país, e seu respectivo impacto na saúde humana e ao ambiente, foram criados programas objetivando a avaliação toxicológica de diversos ingredientes ativos de pesticidas. Dentre esses programas pode ser citado o PARA (Programa de Análise de Resíduos de Agrotóxicos em Alimentos). O PARA, criado em 2001 pela Agência Nacional de Vigilância Sanitária (ANVISA), tem como principal objetivo implantar ações de controle e estruturar um serviço para avaliar a qualidade dos alimentos em relação aos resíduos de pesticidas. 
No ano de 2009 o PARA monitorou mais de três mil amostras, de vinte diferentes tipos de alimentos em todo pais. Nessas análises foram investigados até 234 diferentes ingredientes ativos de pesticidas. Com os resultados obtidos foi elaborado um relatório extenso, onde se constatou alimentos com limite máximo de resíduos (LMR) acima do permitido por lei. Foi avaliada ainda a presença de pesticidas não autorizados (NA) nos alimentos estudados. Em um balanço geral 29,0\% das amostras apresentaram algum tipo de irregularidade. A Figura 6 trás um resumo de algumas culturas avaliadas pelo PARA, e seus respectivos resultados insatisfatórios.

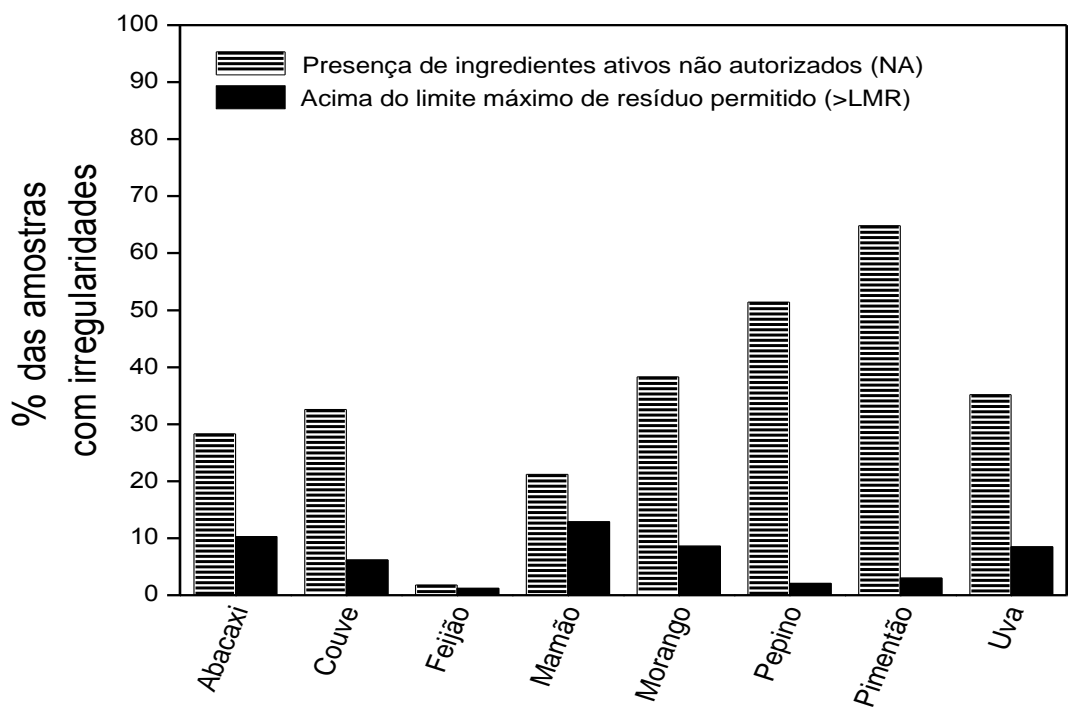

Figura 6. Porcentagem de amostras com irregularidades analisadas por cultura. O gráfico apresenta os resultados insatisfatórios encontrados pelo PARA de 2009 para algumas culturas de alimentos.

$\mathrm{Na}$ classe dos herbicidas, o glifosato vem a ser um dos mais consumidos no pais devido ao seu baixo custo, eficiência e toxicidade relativamente baixa. É utilizado em culturas de arroz irrigado, cana-de-açúcar, café, citros, maçã, milho, pastagens, soja, fumo, uva, e em cana-de-açúcar $^{27}$. Em geral, o glifosato é apresentado para venda numa concentração de $48 \%$ $(\mathrm{m} / \mathrm{v})$, onde as doses aplicadas para as diferentes culturas giram em torno de $5 \mathrm{~L} / \mathrm{ha}^{28}$. 
Existe no Brasil o cultivo de soja geneticamente modificada (GM) tolerante ao herbicida glifosato, onde o uso do herbicida está relacionado ao controle das ervas daninhas prejudiciais ao cultivo desse grão. Dessa forma, o consumo acelerado do herbicida no país tem relação direta com esse fato. Dados de 2009 mostram que $77 \%$ da soja mundial cultivada é geneticamente modificada; no Brasil 21,4 milhões de hectares são cultivados com soja GM, observando-se um crescimento de $86 \%$ em área cultiva em relação a $2006^{29}$.

\subsubsection{Propriedades Físico-Químicas}

Em condições normais o glifosato [N(fosfonometil)glicina] é um herbicida pósemergente e não seletivo. O glifosato (Figura 7) pertence ao grupo químico dos aminoácidos fosfonados e tal como seu precursor, a glicina, apresenta comportamento zwiteriônico.

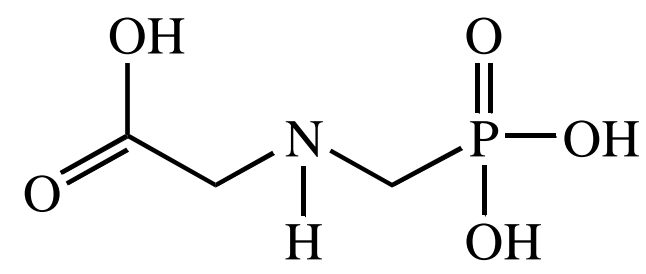

Figura 7. Fórmula estrutural do herbicida glifosato.

As propriedades físico-químicas do glifosato foram descritas por Amarante Jr. e colaboradores $^{27}$. O glifosato tem fórmula molecular $\mathrm{C}_{3} \mathrm{H}_{8} \mathrm{NO}_{5} \mathrm{P}\left(\mathrm{M} . \mathrm{M}=169,7 \mathrm{~g} \mathrm{~mol}^{-1}\right)$, apresenta uma solubilidade em água de $12 \mathrm{~g} \mathrm{~L}^{-1}$ a $25^{\circ} \mathrm{C}$ e é quase insolúvel em solventes orgânicos tais como acetona e etanol. Se funde a $230^{\circ} \mathrm{C}$, possui densidade aparente de $0,5 \mathrm{~g} / \mathrm{cm}^{3}$ e se apresenta bastante estável na presença de luz, inclusive em temperaturas 
superiores a $60^{\circ} \mathrm{C}$. Não possui grupos cromóforos e fluoróforos, impedindo a sua detecção por detectores convencionais (absorção UV/VIS e detectores de fluorescência). A Tabela 1 apresenta um resumo das propriedades físico-químicas do glifosato.

Tabela 1. Propriedades físico-químicas do herbicida glifosato.

\begin{tabular}{|c|c|}
\hline Propriedades & Características \\
\hline Aparência & Sólido Incolor \\
\hline Nomenclatura (IUPAC) & [N-(fosfonometil)-glicina] \\
\hline Peso Molecular & $169,7 \mathrm{~g} \mathrm{~mol}^{-1}$ \\
\hline Estado Físico & Cristalino \\
\hline Solubilidade em Água & $12 g L^{-1}\left(25^{\circ} C\right)$ \\
\hline Solubilidade em Solventes Orgânicos & Insolúvel \\
\hline Ponto de Fusão & $230{ }^{\circ} \mathrm{C}$ \\
\hline Pressão de Vapor (mmHg) & $7,50 \times 10^{-6}\left(20^{\circ} \mathrm{C}\right)$ \\
\hline Categoria Iônica & Anfótero \\
\hline Tempo de meia-vida em água & $33-91$ dias $^{30}$ \\
\hline
\end{tabular}

Segundo Sprankle ${ }^{31}$ e colaboradores, o glifosato apresenta as seguintes constantes de dissociação: 0,8; 2,6; 5,6 e 10,6; como mostrado na Figura 8. Em pH 0,8, o glifosato apresenta carga líquida positiva. Em pH 2,6 o glifosato tem carga zero e acima deste valor, sua carga negativa aumenta com o aumento do valor de $\mathrm{pH}$. Em $\mathrm{pH} 12$, praticamente todo o glifosato está na sua forma trianiônica, sem nenhuma carga positiva. 
<smiles>O=C(O)C[NH+](CC(=O)O)CP(=O)(O)O</smiles><smiles>[1H][NH+](CC(=O)O)CP(=O)([O-])O</smiles><smiles>[1H][NH+](CC(=O)O)CP(=O)([O-])O</smiles>

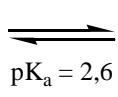<smiles>[1H][NH+](CC(=O)[O-])CP(=O)([O-])O</smiles><smiles>[1H][NH+](CC(=O)[O-])C[P+]([O-])([O-])O</smiles><smiles>C1=C[AsH]=[AsH]1</smiles><smiles>[1H][NH+](CC(=O)[O-])CP(=O)([O-])[O-]</smiles><smiles>O=C([O-])C[NH+]([O-])CP(=O)([O-])[O-]</smiles><smiles></smiles><smiles>O=C([O-])CNCP(=O)([O-])O</smiles>
$+\mathrm{H}^{+}$

Figura 8. Equilíbrios e constantes de dissociação do glifosato.

Alguns microrganismos degradam glifosato em ácido aminometilfosfônico (AMPA), principal metabólito e produto de degradação no ambiente, comumente encontrado por um período de tempo maior em amostras de solo, água e outras matrizes. O mecanismo envolvido trata-se da clivagem da molécula de herbicida através da bactéria Flavobacterium sp ${ }^{32}$ gerando assim o ácido aminometilfosfônico (Figura 9).<smiles>O=C(O)CNC[PH](=O)(O)O</smiles>

Glifosato<smiles>CCCCN</smiles>

Ácido Aminometil Fosfônico (AMPA)

Figura 9. Principal via de degradação microbiológica do glifosato. 
Níveis de AMPA encontrados representam em média cerca de $10 \%$ do glifosato presente (dependendo do tipo de matriz aplicada). Muitos países não consideram o AMPA de importância toxicológica, por isso não se tem estabelecido LMR em culturas onde o glifosato é aplicado. Porém, em alguns países já se tem estabelecido tais limites para o AMPA, pois esse metabólito atua como um marcador de exposição ao glifosato, principalmente nas culturas tolerantes ao herbicida ${ }^{33}$. As propriedades físico-químicas do AMPA são semelhantes ao do glifosato, e sua toxicidade aguda comparada ao composto original é menor para os mamíferos, porém maior para seres aquáticos. A literatura apresenta as constantes de dissociação para o AMPA com certo grau de incerteza; os valores descritos são: $\mathrm{pK}_{\mathrm{a} 1}$ 1,8/ 2,4; $\mathrm{pK}_{\mathrm{a} 2} 5,4 / 5,9 ; \mathrm{pK}_{\mathrm{a} 3} 10,0 / 10,3^{34}$ (Figura 10).<smiles>[NH3+]CP(=O)(O)O</smiles><smiles>[NH3+]CP(=O)([O-])O</smiles><smiles>[NH3+]CP(=O)([O-])O</smiles><smiles>[NH3+]CP(=O)([O-])[O-]</smiles><smiles>[NH3+]CP(=O)([O-])[O-]</smiles><smiles>NCP(=O)([O-])[O-]</smiles>

Figura 10. Equilíbrios e constantes de dissociação do AMPA. 


\subsubsection{Complexos metálicos com glifosato}

O grupo fosfonato do herbicida glifosato possui a capacidade de formar complexos fortes com metais. Características a cerca da biodegradação desse composto são modificadas pela presença de íons metálicos ${ }^{35}$. Os grupos amino e carboxilato, presentes no herbicida, também se coordenam fortemente com metais; principalmente com os de transição. Complexos de $\mathrm{Cu}$ (II) com glifosato são os mais estudados pela comunidade cientifica ${ }^{36}$, possivelmente tal fato tem relação com a importância dos íons cobre para plantas e animais.

Alguns valores de constante de estabilidade para diferentes complexos metálicos são apresentados na Tabela 2. A constante referente ao complexo metálico 1:1(Cu(II):glifosato, $\log \mathrm{K}=11,92$ ) foi obtida através de titulação potenciométrica ${ }^{37}$.

Tabela 2. Constantes de estabilidade (log K) de complexos metálicos com glifosato.

\begin{tabular}{ccccc}
\hline $\mathrm{Cu}(\mathrm{II})$ & $\mathrm{Zn}(\mathrm{II})$ & $\mathrm{Mn}(\mathrm{II})$ & $\mathrm{Ca}(\mathrm{II})$ & $\mathrm{Mg}(\mathrm{II})$ \\
\hline 11,92 & 8,4 & 5,53 & 3,25 & 3,25 \\
\hline
\end{tabular}

\subsubsection{Toxicidade}

Os herbicidas organofosforados afetam o sistema nervoso central de mamíferos e invertebrados (devido a inibição da enzima acetilcolinesterase), entretanto o glifosato não possui essa característica ${ }^{38}$. Mesmo sendo citado como pouco tóxico, efeitos deletérios a saúde humana e ao meio ambiente são verificados. Em contato direto com humanos pode causar irritações dérmicas, danos hepáticos e renais dentre outros ${ }^{39}$. Algumas manifestações clínicas comumente presentes nas intoxicações agudas (sintomas e sinais imediatos) por glifosato são apresentadas por tipo de sistema na Tabela $3^{40}$. 
Tabela 3. Manifestações clínicas agudas do glifosato por sistema.

\begin{tabular}{ll}
\hline Sistema & \multicolumn{1}{c}{ Sintomas } \\
\hline Cardiovascular & $\begin{array}{l}\text { choque, disritmia, taquicardia, palpitações, arritmia ventricular, } \\
\text { hipotensão, bradicardia e parada cardíaca. }\end{array}$ \\
Dermatológico & irritação, piloereção, eritema, dermatite de contato. \\
Endócrino & $\begin{array}{l}\text { acidose metabólica, hipertermia; elevação da amilase sérica, } \\
\text { bilirrubina e desidrogenase láctica; hiperpotassemia. } \\
\text { náuseas, vômitos, hiperemia da mucosa, odinofagia, disfonia, } \\
\text { aumento da salivação, erosão, ulceração, esofagite, gastrite. } \\
\text { Gastrointestinal }\end{array}$ \\
Gecrose tubular aguda, insuficiência renal hematúria, oligúria, \\
anúria. \\
Hematopoético
\end{tabular}

Alguns estudos relatam que o herbicida glifosato pode apresentar diversos efeitos negativos em animais por exposições longas de tempo. Granja e colaboradores ${ }^{41}$ apresentam o glifosato como uma substância que não apresenta evidências de carcinogenicidade em humanos. Entretanto, estudos recentes demonstram discordância com esses autores, onde evidências experimentais demonstram uma relação direta da exposição longa à glifosato com a formação de células cancerígenas ${ }^{42}$. 


\subsubsection{Legislação}

Segundo a ANVISA (Agência Nacional de Vigilância Sanitária) - Portaria nº 518/2004 - o valor máximo permitido de glifosato em água potável é de $500 \mu \mathrm{g} \mathrm{L}{ }^{-1}$. O CONAMA (Conselho Nacional de Meio Ambiente) - resolução no 357/2005 - estabeleceu um limite máximo de glifosato em águas de superfície igual a $65 \mu \mathrm{g} \mathrm{L}^{-1}$ para águas classe 1 ou 2 e de $180 \mu \mathrm{g} \mathrm{L}^{-1}$ para águas classe $3^{43}$. (Classificação das águas - classe 1: abastecimento público após tratamento simples, recreação, irrigação de hortaliças e frutas e criação de espécies de consumo humano; -classe 2: difere da classe 1 pelo primeiro item: abastecimento público após tratamento convencional e classe 3: abastecimento público após tratamento convencional, irrigação de culturas arbóreas, cereais e forragens e dessedentação de animais.)

Em relação ao Limite Máximo de Resíduo (LMR) de glifosato em alimentos, a legislação, no Brasil, é estabelecida pela ANVISA. A Tabela 4 apresenta os LMR de glifosato em alguns alimentos, segundo estes órgãos.

Tabela 4. Limite máximo de resíduo de glifosato em alguns alimentos.

\begin{tabular}{cc}
\hline Alimento & ANVISA $\left(\mathbf{m g ~ K g}^{-\mathbf{1}}\right)$ \\
\hline Algodão & 3 \\
Arroz & 0,2 \\
Banana & 0,02 \\
Cana-de-açúcar & 1 \\
Feijão & 0,05 \\
Maça & 0,2 \\
Milho & 0,1 \\
Uva & 0,2 \\
Citrus & 0,2 \\
Soja & 10 \\
\hline
\end{tabular}




\subsubsection{Metodologias de análise do glifosato}

Quando técnicas cromatográficas associadas à detecção por UV, fluorescência ou espectrometria de massa são utilizadas na determinação de glifosato, reações de derivatização são necessárias. Tal fato ocorre devido à ausência de grupos cromóforos na molécula, tanto quanto a alta polaridade apresentada pelo herbicida. Assim sendo, o uso de reagentes de derivatização elevam o custo e o tempo das analise.

A fluorescência é o método de detecção mais usado para determinação de glifosato $^{44-46}$. Os reagentes de derivatização mais utilizados são o-ftalaldeído (OPA), 9-fluorenilmetilcloroformato (FMOC) e o cloreto de p-toluenosulfonila. Jiang ${ }^{47}$ usou extração em fase sólida (SPE) como etapa de pré concentração, e como agente de derivatização naftaleno-2,3-dicarboxialdeído (NDA) para determinação de glifosato. A técnica de cromatografia eletrocinética micelar (MEKC) foi também utilizada, onde os valores de limite de detecção alcançados por esse autor foi na ordem de nano mols $\mathrm{L}^{-1}$.

Vários trabalhos determinando glifosato tendo UV como sistema de detecção, aliado a sistemas cromatográficos, são encontrados na literatura ${ }^{48-50}$. Recentemente $\operatorname{Sun}^{51} \mathrm{e}$ colaboradores desenvolveram um método baseado no uso de um novo agente de derivatização (fluoreto de 4-metoxibenzenosulfonil) para determinação de glifosato e AMPA em amostras de água. Com simples pré-concentração por evaporação, os autores obtiveram LD de $0,1 \mu \mathrm{g} \mathrm{L}{ }^{-1}$ para ambos analitos.

De acordo com a literatura, a utilização de técnicas cromatográficas associadas à espectrometria de massas (MS) sem reações de derivatização não apresentam bom desempenho ${ }^{52}$. Após reação de derivatização, Motojyuku et al. ${ }^{53}$ promoveram a separação de glifosato, AMPA e glifosinato em cromatografia gasosa seguido de detecção por espectrometria de massas; recuperações entre 82 e $103 \%$ foram encontradas. A aplicabilidade 
do método foi avaliada em amostras de soro humano de pacientes intoxicados com glifosato. Outros trabalhos são encontrados usando MS como sistema de detecção, entretanto em sua maioria apresentando etapas de derivatização ${ }^{54-56}$.

Alguns relatos do uso de técnicas eletroquímicas na determinação de glifosato são encontrados ${ }^{57,58}$. Moraes et al. ${ }^{59}$ modificaram a superfície de um eletrodo de carbono vítreo com um filme contendo ftalocianinas de cobre adsorvidas em nanotubos de carbono, e posteriormente utilizaram tal sistema na detecção de glifosato. Empregando a técnica de voltametria de pulso diferencial o autor encontrou limites de detecção de $2 \mu \mathrm{g} \mathrm{L}^{-1}$ para glifosato.

Alem das técnicas cromatográficas, a eletroforese capilar de zona (CZE) também é usada como método de separação na determinação do herbicida glifosato ${ }^{60-63}$. Através da técnica de microextração em fase sólida (SPME), Hsu e Whang $^{64}$ utilizaram partículas eletromagnéticas com afinidade para glifosato e AMPA, para promover a pré-concentração desses analitos em amostras de água e frutas. As partículas foram lavadas com solução fosfato depois de serem isoladas da amostra pela aplicação de um campo magnético, e em seguida injetadas em sistema eletroforético seguido de detecção por eletroquimioluminescência. Limites de detecção de 0,3 e $30 \mu \mathrm{g} \mathrm{L}^{-1}$ foram encontrados para glifosato e AMPA respectivamente.

Este trabalho apresenta o desenvolvimento de metodologias para a determinação direta (sem reações de derivatização) do herbicida glifosato e seu maior metabólito AMPA. Microdispositivos eletroforéticos fabricados em poliéster-toner são utilizados, onde em uma primeira etapa detecção por condutometria sem contato $\left(C^{4} D\right)$ é utilizada, e em uma segunda etapa detecção cronoamperométrica. Toda instrumentação usada é de simples operação, fabricação lab-made, de extremo baixo custo agregado e com potencial para portabilidade. Etapas de pré-concentração off-line também não foram usadas neste trabalho. 


\section{OBJETIVOS}

O objetivo geral deste trabalho é desenvolver e otimizar metodologias simples e de baixo custo para a determinação direta de glifosato, com potencial para portabilidade, e posterior aplicação em amostras de interesse ambiental.

\section{- Objetivos secundários}

- Estudar a viabilidade do método de detecção $C^{4} \mathrm{D}$ acoplado à microdispositivo eletroforético fabricado em poliéster-toner na determinação do herbicida glifosato, e seu maior metabólito (AMPA).

- Usando técnicas eletroquímicas, averiguar entre eletrodo de cobre e ouro, qual metal apresenta maior sensibilidade para glifosato.

- Integrar a detecção amperométrica aos microdispositivos fabricados em poliéstertoner, com posterior determinação de glifosato e AMPA.

- Realizar testes de aplicabilidade com os métodos desenvolvidos em amostras reais. 


\section{DETECÇÃO DE GLIFOSATO UTILIZANDO C ${ }^{4} D$}

Neste capitulo serão apresentados estudos realizados no desenvolvimento de uma metodologia para determinação simultânea de glifosato e AMPA utilizando $\mathrm{C}^{4} \mathrm{D}$ como sistema de detecção, aliado a eletroforese em microchips fabricados em poliéster-toner (PT). Vários parâmetros que regem uma boa confiabilidade analítica, tanto quanto otimizam a sensibilidade do método, foram avaliados e serão mostrados a seguir. Por fim, resultados a cerca da aplicabilidade do método são apresentados.

\subsection{Introdução}

A detecção condutométrica sem contato capacitivamente acoplada $\left(C^{4} \mathrm{D}\right.$, capacitively coupled contactless conductivity detection), foi inicialmente aplicada às técnicas de eletromigração em 1980 para a determinação isotacoforética de íons pequenos ${ }^{65}$. Zemann e colaboradores $^{66}$, e Fracassi da Silva e Lago ${ }^{67}$ propuseram em 1998 a utilização da $C^{4}$ D como método de detecção para eletroforese capilar; desde então vários pesquisadores tem utilizado essa técnica de detecção acoplada a CE. A $\mathrm{C}^{4} \mathrm{D}$, conhecida também como detecção oscilométrica (DO), vem a ser uma alternativa à detecção condutométrica convencional (com contato); apresentando vantagens como a ausência de inconvenientes relacionados ao contato eletrodo/solução, como: passivação, degradação e formação de bolhas na superfície dos eletrodos.

Em detecção condutométrica (com contato e sem contato) a sensibilidade está estritamente ligada à diferença de condutividade entre o tampão de corrida e a zona da amostra que migra no capilar. A detecção condutométrica, a principio, é um método de 
detecção universal desde que os analitos forneçam uma resposta mensurável. Em condutometria sem contato $\left(C^{4} D\right)$ um sinal senoidal é aplicado a um dos eletrodos, com uma frequência da ordem de centenas de $\mathrm{kHz}$, o que difere bastante das frequências aplicadas em detectores condutométricos convencionais, nos quais aplicam-se, tipicamente, algumas unidades de kHz. Com a aplicação desse sinal senoidal a um dos eletrodos, uma corrente alternada pode ser acoplada capacitivamente no eletrólito de trabalho e registrada no segundo eletrodo de medida.

O surgimento de uma corrente elétrica mesmo com os eletrodos estando sem contato com a solução, se deve a formação de capacitores entre os eletrodos e a solução eletrolítica utilizada $^{68}$. Estes capacitores são caracterizados pela impedância, $X_{c}$, conhecida também como reatância capacitiva, a qual é inversamente dependente da capacitância, C, que é calculada pela Equação 8

$$
X_{C}=\frac{1}{\omega C}
$$

sendo que $C$ representa a capacitância, e $\omega$ é dado por $(2 \pi \times$ frequência $)$

De acordo com a Equação 8, quanto maior a frequência de trabalho, menor a reatância capacitiva que um capacitor oferece ao fluxo de carga, permitindo que as variações de condutividade da solução no interior do microcanal sejam observadas mesmo com os eletrodos estando sem contato com a solução.

A Figura 11 apresenta o circuito equivalente formado para $C^{4} \mathrm{D}$, quando montado em microdispositivos eletroforéticos. Observa-se na Figura 11 a formação de capacitores entre os eletrodos planares e a solução eletrolítica $\left(\mathrm{C}_{1}\right.$ e $\left.\mathrm{C}_{2}\right)$; tanto quanto a formação de um resistor $\left(\mathrm{R}_{\mathrm{s}}\right)$ dentro do canal do microdispositivo, associado ao fluído eletrolítico ${ }^{69}$. Verifica-se também a formação de uma capacitância denominada capacitância de fuga $\left(\mathrm{C}_{0}\right)$, referente ao acoplamento capacito entre os dois eletrodos da cela de detecção. Esta capacitância é 
indesejada, pois reduz a corrente elétrica que se direciona ao detector, afetando negativamente a sensibilidade. Considerando as teorias comentadas, a ideia básica dos sistemas $\mathrm{C}_{4} \mathrm{D}$ se resume na aplicação de um sinal senoidal no eletrodo de excitação $\left(\mathrm{e}_{\mathrm{ex}}\right)$, onde o eletrodo receptor $\left(\mathrm{e}_{\mathrm{re}}\right)$ fica responsável pelo registro de corrente gerada. Corrente essa diretamente proporcional a concentração do analito.

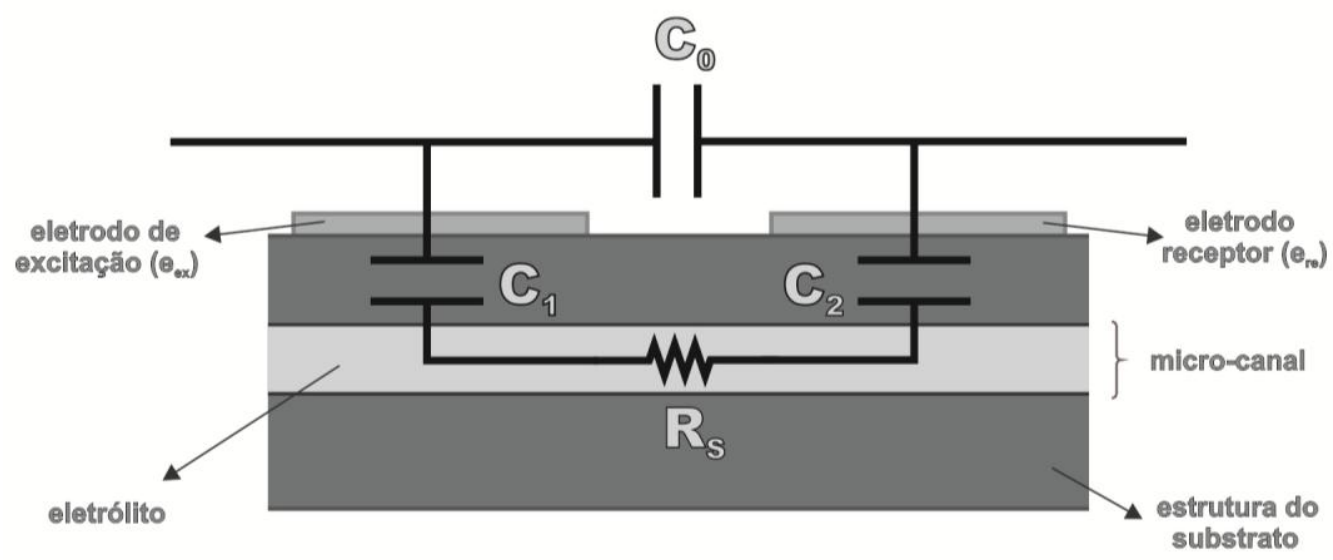

Figura 11. Modelo elétrico referente ao sistema de detecção $\mathrm{C}^{4} \mathrm{D}$.

\subsection{Parte Experimental}

\subsubsection{Reagentes}

Durante o desenvolvimento experimental foram usados apenas reagentes de pureza analítica, tentando-se evitar a presença de contaminantes e dessa forma assegurar confiabilidade dos resultados analíticos. Estes reagentes estão listados na Tabela 5, com suas respectivas procedências e purezas. 
Tabela 5. Procedência e pureza dos reagentes utilizados.

\begin{tabular}{lcc}
\hline \multicolumn{1}{c}{ Reagentes } & Procedência & $\begin{array}{c}\text { Pureza } \\
(\boldsymbol{\%})\end{array}$ \\
\hline Ácido aminometilfosfônico (AMPA) & Aldrich & 99 \\
Arginina & Fluka-Chemica & 99 \\
Bicarbonato de sódio & MERCK & 99 \\
Carbonato de sódio & MERCK & 99 \\
Ácido 2-[N-cicloexamino]etanossulfônico (CHES) & Sigma & 99 \\
Fosfato de sódio dibásico & J. T. Bake & 99 \\
Fosfato de sódio monobásico & Mallinckrodt & 98 \\
Glifosato & Milenia Agrociências & 97 \\
Histidina (His) & Aldrich & 99 \\
Ácido 2-[N-morfolino]etanossulfônico (MES) & Sigma & 99 \\
Tetraborato de sódio & Fluka & 99 \\
Tris(hidroximetil)aminometano (TRIS) & MERCK & 99 \\
\hline
\end{tabular}

\subsubsection{Soluções}

Todas as soluções aquosas empregadas no procedimento experimental foram preparadas utilizando água ultrapura proveniente de um sistema de deionização MilliQ da Millipore $^{\circledR}$.

\subsubsection{Soluções de glifosato e AMPA}

As soluções estoque dos padrões de glifosato e AMPA foram preparadas antes de cada ensaio analítico numa concentração de $50 \mathrm{mmol} \mathrm{L}^{-1}$ em água ultrapura (Milli-Q), e diluídas conforme necessidade. 


\subsubsection{Soluções de eletrólitos}

Para o estudo da escolha do eletrólito vários sistemas foram investigados. A solução tampão carbonato foi preparada na concentração de $20 \mathrm{mmol} \mathrm{L}^{-1}(\mathrm{pH} 11,4)$ em água ultrapura (Milli-Q). Preparou-se também soluções de tampão fosfato $(\mathrm{pH} 7,5)$ e de tampão borato (pH 9,4), ambos numa concentração de $20 \mathrm{mmol} \mathrm{L}^{-1}$ em água ultrapura (Milli-Q).

Os sistemas CHES/Arginina $(\mathrm{pH} 9,2)$ e MES/His ( $\mathrm{pH}$ 5,8) foram preparados a $20 \mathrm{mmol} \mathrm{L}^{-1}$ em água ultrapura (Milli-Q). O eletrólito composto CHES/Tris foi estudado como eletrólito de trabalho em diferentes concentrações e proporções, para isso uma solução estoque de CHES e outra de Tris foram preparadas numa concentração de $0,5 \mathrm{~mol} \mathrm{~L}{ }^{-1}$.

\subsubsection{Instrumentação}

Todos os compostos foram pesados em uma balança analítica digital Mettler Toledo ${ }^{\circledR}$ modelo AL204, com legibilidade da pesagem de 0,1 mg. As soluções estoques de glifosato e AMPA foram homogeneizadas em um banho de ultra-som da Thorniton ${ }^{\circledR}$.

Os valores de $\mathrm{pH}$ para as diferentes proporções do eletrólito composto CHES/Tris foram medidos em pHmetro digital da Qualxtron $^{\circledR}$ modelo 8010 , usando eletrodo de vidro combinado. 


\subsubsection{Componentes do sistema de detecção $C^{4} \mathrm{D}$}

O detector oscilométrico foi construído, de acordo com a eletrônica desenvolvida por Fracassi da Silva e do Lago ${ }^{70}$. Na Figura 12 é apresentado um diagrama de funcionamento do sistema de detecção $C^{4} \mathrm{D}$ utilizado. De acordo com a Figura, um sinal senoidal de frequência da ordem de centenas de $\mathrm{kHz}$ é aplicado, através de um gerador de funções, ao eletrodo de excitação da cela de detecção $\left(\mathrm{e}_{\mathrm{ex}}\right)$. Ao se aplicar esse sinal, a corrente flui pelo dispositivo sendo capturada pelo eletrodo receptor $\left(\mathrm{e}_{\mathrm{re}}\right)$, refletindo todos os possíveis caminhos percorridos pelo sinal. Após a transformação do sinal de corrente em tensão, pelo conversor i/e (a), segue-se a retificação do sinal efetuado por um circuito retificador de precisão, operando em meia onda (b). O sinal resultante é filtrado e amplificado antes de passar pela etapa de compensação da linha de base (offset). O sinal analógico é então enviado para uma interface analógica/digital (A/D) para aquisição de dados.

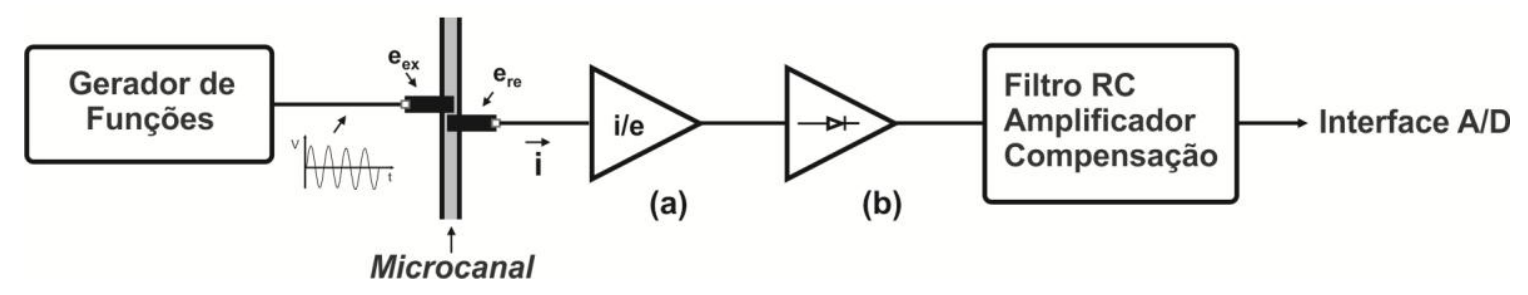

Figura 12. Diagrama do sistema de detecção oscilométrica simples em microssistemas. O eletrodo de excitação e o eletrodo receptor estão representados por $\mathbf{e}_{\mathbf{e x}}$ e $\mathbf{e}_{\mathbf{r e}}$, respectivamente. As etapas (a) e (b) indicam os estágios de conversão da corrente em tensão e retificação do sinal, respectivamente.

\section{-Gerador de funções}

Um gerador de funções MFG 4202 (Minipa, São Paulo, SP) foi utilizado para promover o sinal de excitação. Esse gerador é capaz de gerar formas de onda senoidal, 
quadrada e triangular na faixa de frequência de $0,2 \mathrm{~Hz}$ a $2 \mathrm{MHz}$, com ajuste de amplitude (1 a 20 V) e simetria da onda. A impedância de saída do gerador é de $50 \Omega$.

-Software de aquisição de dados

O software de aquisição foi escrito em LabVIEW ${ }^{\circledR}$, e foi desenvolvido por alunos do grupo de pesquisa BioMicS do Instituto de Química de São Carlos ${ }^{71}$. O software controla e exibe, em tempo real, o sinal do detector e a corrente gerada no interior dos microcanais devido à aplicação de um campo elétrico. A interface do programa permite a seleção dos potenciais elétricos para injeção e separação, além do tempo de injeção; onde a planilha gerada pode ser arquiva em extensões de fácil manuseio em softwares gráficos.

-Fonte de alta tensão

No sistema de separação eletroforético, o manuseio eletrocinético dos líquidos nos canais microfluídicos foi realizado com o auxílio de uma fonte de alta tensão (CZE 1000R, Spellman, NY), com capacidade de aplicação de potencial de até $30 \mathrm{kV}$. A aquisição de dados foi realizada com uma interface A/D comercial da National Instruments (modelo NI USBA6009) com porta USB para comunicação com o microcomputador, cuja resolução é de 14 bits.

\subsubsection{Microchips de poliéster-toner}

O processo de microfabricação dos dispositivos fabricados em poliéster-toner (PT) seguiu o processo descrito por do Lago e colaboradores ${ }^{72}$. A confecção desses dispositivos se dá basicamente pela impressão direta de padrões de imagem (layout) em folhas de 
transparência com subsequente etapa de laminação. Dessa forma, a estrutura dos microcanais fabricados pelo processo de impressão direta fica definida por filmes de poliéster (base e tampa) e por uma camada de toner (paredes). Esse tipo de microdispositivo possui como maiores vantagens o baixo custo, e um curto intervalo de tempo para confecção. Podendo dessa forma, ser utilizados como dispositivos descartáveis. Um esquema resumido do processo de fabricação se encontra na Figura 13.
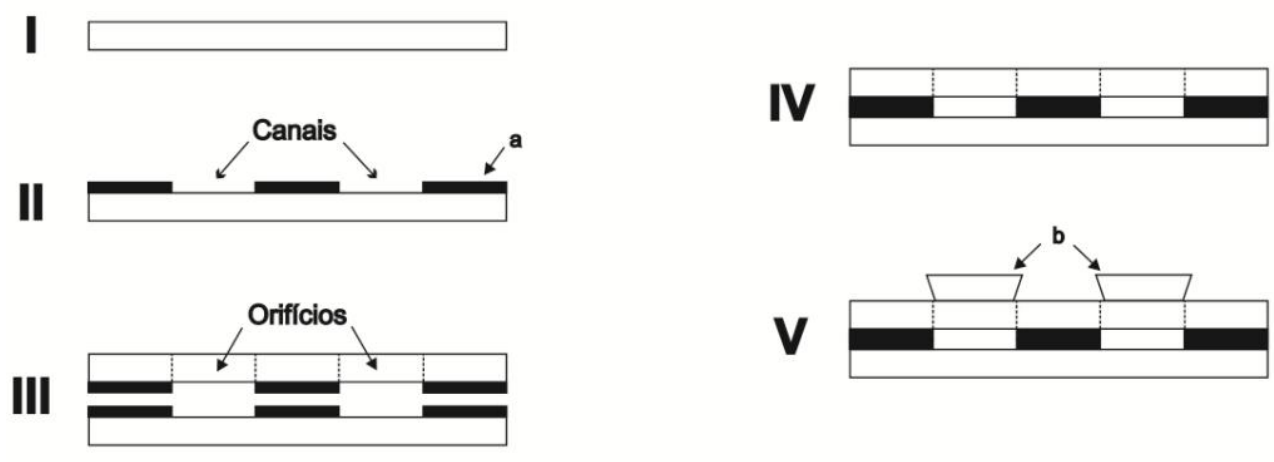

Figura 13. Etapas do processo de microfabricação baseado na impressão direta: (I) filme de poliéster; (II) filme de poliéster com uma camada de toner (a) depositada; (III) alinhamento entre o esquema do dispositivo impresso no filme de poliéster e sua imagem especular com acesso aos reservatórios; (IV) etapa de laminação e; (V) microdispositivo finalizado com reservatórios (b) colados (tubos de PVC ou a base de ponteiras de pipetadores de $100 \mu \mathrm{L}$ ).

Uma camada de toner é depositada na folha transparência, pela impressora, de modo a formar os microcanais (II). A espessura da camada de toner, representada pela coloração preta, define a altura dos microcanais obtidos e as regiões brancas representam os reservatórios e microcanais formados. A vedação dos microcanais é realizada através de uma etapa de laminação térmica. Para se obter o dispositivo, o padrão é impresso juntamente com sua imagem especular em uma mesma transparência. Antes da etapa de laminação, orifícios devem ser feitos diretamente nos centros dos reservatórios da imagem especular do dispositivo com auxílio de um perfurador de papel. O padrão do dispositivo e a imagem 
especular, contendo os orifícios, devem ser alinhados (III) e laminados (IV) juntos. Os detalhes de cada etapa apresentada na Figura 13 são discutidos a seguir.

\section{-Layout e impressão}

Para a elaboração dos padrões de imagem dos microdispositivos, o software Corel Draw versão 14.0 foi utilizado. Os padrões foram impressos em transparência modelo CG 3300 da $3 \mathrm{M}^{\circledR}$ (etapa II da Figura 13), utilizando a impressora (modelo Laser Jet 1200, Hewlett Packard) com resolução em 600 dpi.

O layout da Figura 14, usado para confecções dos microchips, possui um canal de separação de $50 \mathrm{~mm}$ de comprimento do ponto $b$ ao $d$, canal de injeção de 7,5 $\mathrm{mm}$ de comprimento, totalizando $15 \mathrm{~mm}$ do reservatório do ponto $a$ ao $c$. Possui configuração em forma de cruz, e canais de $150 \mu \mathrm{m}$ de largura. O sinal guia mostrado na Figura 14 é utilizado para posicionamento do eletrodo de excitação do sistema $\mathrm{C}^{4} \mathrm{D}$.

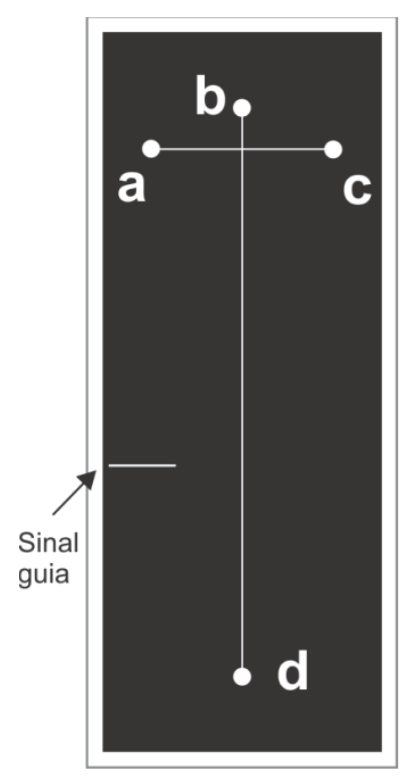

Figura 14. Padrão de imagem utilizado para confecção dos microchips de poliéster-toner. 
-Selagem

Antes do processo de selagem, um alinhamento preciso entre o layout impresso e sua imagem espelhada deve ser realizado (etapa III da Figura 13). Após perfuração dos reservatórios da imagem espelhada, o alinhamento foi realizado de tal forma que o toner de ambas imagens fiquem em contato; promovendo assim a formação de um canal com aproximadamente $12 \mu \mathrm{m}$ de profundidade ${ }^{73}$. O alinhamento é obtido quando se obtém o máximo de contraste nos canais. Feito o alinhamento, cola-se pedaços de fita adesiva previamente cortadas para que o alinhamento seja mantido.

Após alinhamento, o processo de selagem (etapa IV da Figura 13) foi realizado usando-se uma plastificadora rotativa de documentos do tipo polaseal modelo Gazela AC91-230. A temperatura foi ajustada a aproximadamente $120{ }^{\circ} \mathrm{C}$ para promover a fusão do toner. Uma folha de papel parafinado foi utilizada de tal forma a envolver o microdispositivo, logo em seguida a selagem é realizada. Por fim, tubos de PVC ou base de ponteiras de pipetadores de $100 \mu \mathrm{L}$ são estrategicamente colados e utilizados como reservatório.

\section{-Posicionamento dos eletrodos e considerações gerais}

Os eletrodos para $\mathrm{C}^{4} \mathrm{D}$ foram fabricados através do uso de fitas adesivas de cobre. As fitas foram recortadas em dimensões de aproximadamente $2 \mathrm{~mm}$ de largura por $20 \mathrm{~mm}$ de comprimento, e fixadas sobre os dispositivos. A espessura da tampa do dispositivo limita a distância dos eletrodos aos microcanais. No caso do poliéster, a espessura é de $100 \pm 10 \mu \mathrm{m}^{72}$.

A fabricação de eletrodos para $C^{4} \mathrm{D}$ com fitas adesivas metálicas é vantajosa devido à simplicidade e ao custo reduzido. Obedecendo ao sinal guia, os eletrodos foram posicionados no microchip de maneira antiparalela, promovendo assim um caminho efetivo no canal de separação de $30 \mathrm{~mm}$. Procurou-se manter uma distância de um eletrodo a outro de 
aproximadamente $1 \mathrm{~mm}$. A Figura 15 apresenta uma imagem ilustrativa do microchip com seus respectivos eletrodos para $\mathrm{C}^{4} \mathrm{D}$.

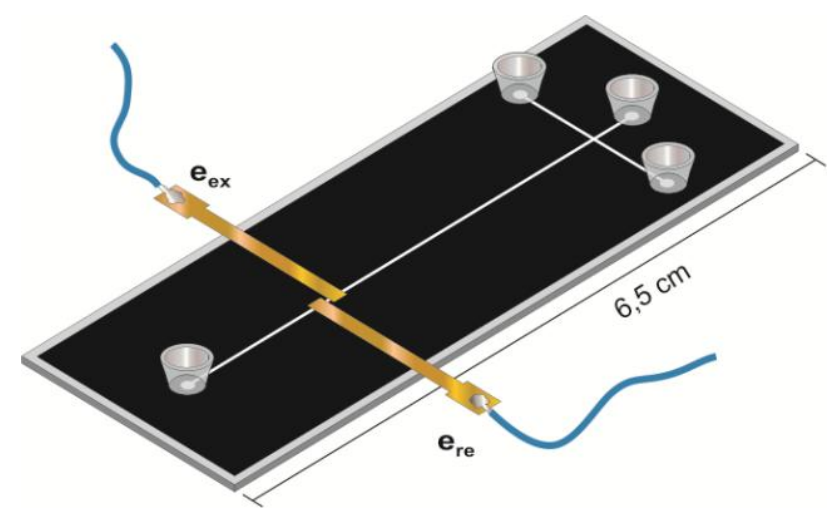

Figura 15. Representação do microchip fabricado em poliéster-toner com seus respectivos eletrodos para detecção $C^{4} D$. Os pontos $\mathbf{e}_{\mathbf{e x}}$ e $\mathbf{e}_{\mathbf{r e}}$ indicam os eletrodos para excitação da cela e registro do sinal resultante, respectivamente.

Vários estudos a cerca da caracterização da superfície e da composição do toner foram realizados em microdispositivos desse tipo por Wendell Coltro em seu trabalho de mestrado ${ }^{74}$. Tal estudo tinha como objetivo um melhor entendimento da composição química da estrutura dos microcanais. Em seu trabalho o autor apresenta também, um estudo avaliando as dimensões limites dos canais em termos de largura e altura. De um modo geral, a dissertação desse autor demonstra a eficiência e aplicabilidade dos dispositivos de PT, apresentando sua simplicidade de confecção e o baixo custo envolvido (na ordem de $\mathrm{R} \$ 0,15$ por dispositivo). 


\subsection{Resultados e discussão}

\subsubsection{Escolha do eletrólito}

Para a escolha do eletrólito de trabalho (BGE), foi levado em conta como ideia central, o uso de um eletrólito que apresentasse um melhor compromisso entre separação e sensibilidade. Assim sendo, algumas propriedades a cerca do BGE foram consideradas.

Conhecendo as constantes de ionização do glifosato e do AMPA, BGEs com alto valor de $\mathrm{pH}$ foram testados com intuito de promover a desprotonação desses analitos, deixando-os suscetíveis à separação eletroforética.

A escolha do eletrólito também tem influência direta sobre a forma da banda; onde, via de regra, sistemas tamponantes contendo íons com mobilidade semelhante à do analito previnem distorções no perfil da banda e minimizam o seu alargamento ${ }^{75}$. Com base em alguns trabalhos apresentando valores de mobilidade para diferentes espécies aniônicas (incluindo glifosato e AMPA) ${ }^{76,77}$, alguns BGEs foram selecionados para estudo.

Basicamente, em $\mathrm{C}^{4} \mathrm{D}$ o sinal do detector surge em função da diferença de condutividade entre o analito estudado e o co-íon do BGE ${ }^{78}$. Dessa forma, a condutância do eletrólito de trabalho é outro fator a ser considerado, pois uma maior diferença entre a condutância do analito e o BGE gera uma maior relação sinal/ruído. Normalmente, eletrólitos de trabalho com baixos valores de condutância são utilizados ${ }^{79}$.

Dentre os vários sistemas utilizados como BGE, a combinação MES/His foi investigada, e um sinal apenas para glifosato foi observado (Figura 16). Nesse estudo uma mistura de glifosato e AMPA ambos a $2 \mathrm{mmol} \mathrm{L}^{-1}$, foi utilizada. A ausência de um sinal analítico para AMPA pode estar associado ao fato de que, no $\mathrm{pH}$ de trabalho do sistema MES/His ( $\mathrm{pH} 5,8$ ), uma quantidade significativa desse analito não se encontra eletricamente 
carregada; desfavorecendo assim a injeção de uma quantidade mensurável do mesmo por diferença de potencial (injeção eletrocinética).

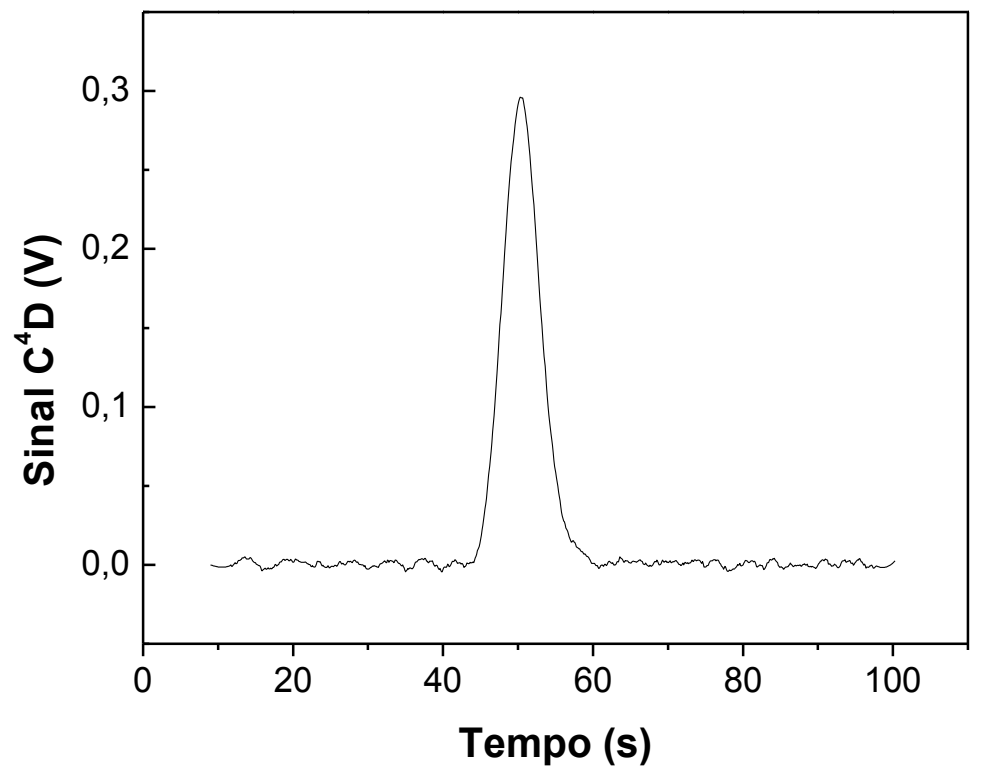

Figura 16. Eletroferograma obtido para uma mistura de glifosato e AMPA (ambos a $2 \mathrm{mmol} \mathrm{L}^{-1}$ ). Condições: Tampão MES/His (50 mmol L $\mathrm{L}^{-1}$ ), $\mathrm{pH}$ 5,8. Injeção:-1,0kV/10 s; potencial de separação: $-1,0 \mathrm{kV}$. Frequência do sinal senoidal para detecção $\mathrm{C}^{4} \mathrm{D}: 450 \mathrm{kHz}$. Amplitude: $3,0 \mathrm{~V}_{\mathrm{pp}}$.

A mistura CHES/Arginina também foi testada como BGE. A separação eletroforética do herbicida e seu metabólito foi obtida. Porem os eletroferogramas apresentaram picos mal definidos, com pouca simetria e significativo alargamento de banda. Esse resultado pode ter ocorrido devido à maior diferença de mobilidade entre os analitos e o co-íon do BGE, quando comparado ao sistema MES/His ${ }^{76}$

Dentre os diferentes eletrólitos de trabalho testados - incluindo tampões inorgânicos (tampão fosfato, tampão carbonato, tampão borato) - o sistema que apresentou um maior compromisso entre separação e sensibilidade foi o eletrólito de trabalho CHES/Tris. O eletroferograma apresentado na Figura 17 mostra uma separação eficiente entre o glifosato 
(A) e seu metabólito, AMPA (B). Com base nesses resultados, o eletrólito de trabalho CHES/Tris foi escolhido para realização de estudos posteriores.

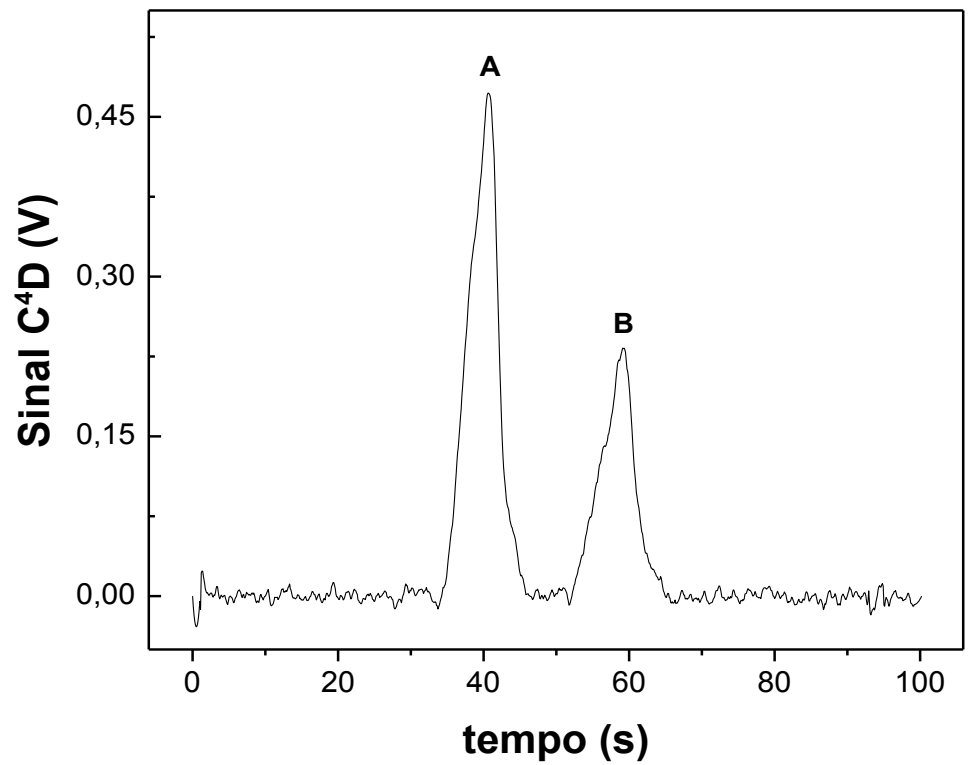

Figura 17. Eletroferograma apresentando a separação de uma mistura contendo glifosato $(A)$ e AMPA (B), ambos a $2 \mathrm{mmol} \mathrm{L}^{-1}$. Condições: Tampão CHES/Tris $\left(60 \mathrm{mmol} \mathrm{L}^{-1}\right), \mathrm{pH} 9,0$. Outras condições: ver Figura 16.

Cabe ressaltar que os analitos estudados (glifosato e AMPA) encontram-se em sua forma aniônica, e assim sendo foram separados e detectados nos microdispositivos de PT utilizando polaridade invertida. Isso indica que a magnitude das mobilidades eletroforéticas de cada ânion é maior que a mobilidade eletrosmótica gerada nos canais de PT.

De acordo com a Equação 9, a mobilidade observada $\left(\mu_{a}\right)$ no eletroferograma, é resultado da soma da mobilidade eletroforética da espécie $\left(\mu_{e p}\right)$ com a mobilidade eletrosmótica $\left(\mu_{e o}\right)$. Para espécies negativas a $\mu_{e p}$ tem sinal negativo e tende a migrar contra a direção do fluxo eletrosmótico (EOF). Neste caso, se a $\mu_{e p}$ for muito maior, em módulo, que a magnitude do EOF, a espécie em questão não será introduzida no microcanal sobre polaridade normal $^{71}$.

$$
\mu_{a}=\mu_{e p}+\mu_{e o}
$$




\subsubsection{Estudo da frequência e amplitude}

Assim como outros sistemas de detecção, alguns dos parâmetros operacionais em $\mathrm{C}^{4} \mathrm{D}$ devem ser otimizados a fim de se obter uma maximização de resposta em termos de sensibilidade. Na detecção oscilométrica as variáveis frequência e amplitude são de essencial importância, e nesse trabalho foram avaliadas a partir da área do pico obtido para o glifosato.

A Figura 18A apresenta os valores de área de pico para o glifosato em função da frequência, onde um valor de amplitude de $3 \mathrm{~V}_{\mathrm{pp}}$ foi mantido fixo durante as medidas. Nessa figura, a janela de frequência estudada varia de 150 a $550 \mathrm{kHz}$ de acordo com as limitações do instrumento, com intervalos de $100 \mathrm{kHz}$ de um ponto a outro.

Com base nos resultados encontrados, uma nova janela com uma menor faixa de frequência foi estudada (de 280 a $420 \mathrm{kHz}$ ), com variações de $20 \mathrm{kHz}$ de um ponto a outro (Figura 18B). Tal procedimento foi adotado com o intuito de se realizar uma busca mais "fina" pela frequência dita como ótima. Como observado na Figura 18B o valor de frequência em que a área do pico para glifosato atinge um ponto máximo é em $320 \mathrm{kHz}$.
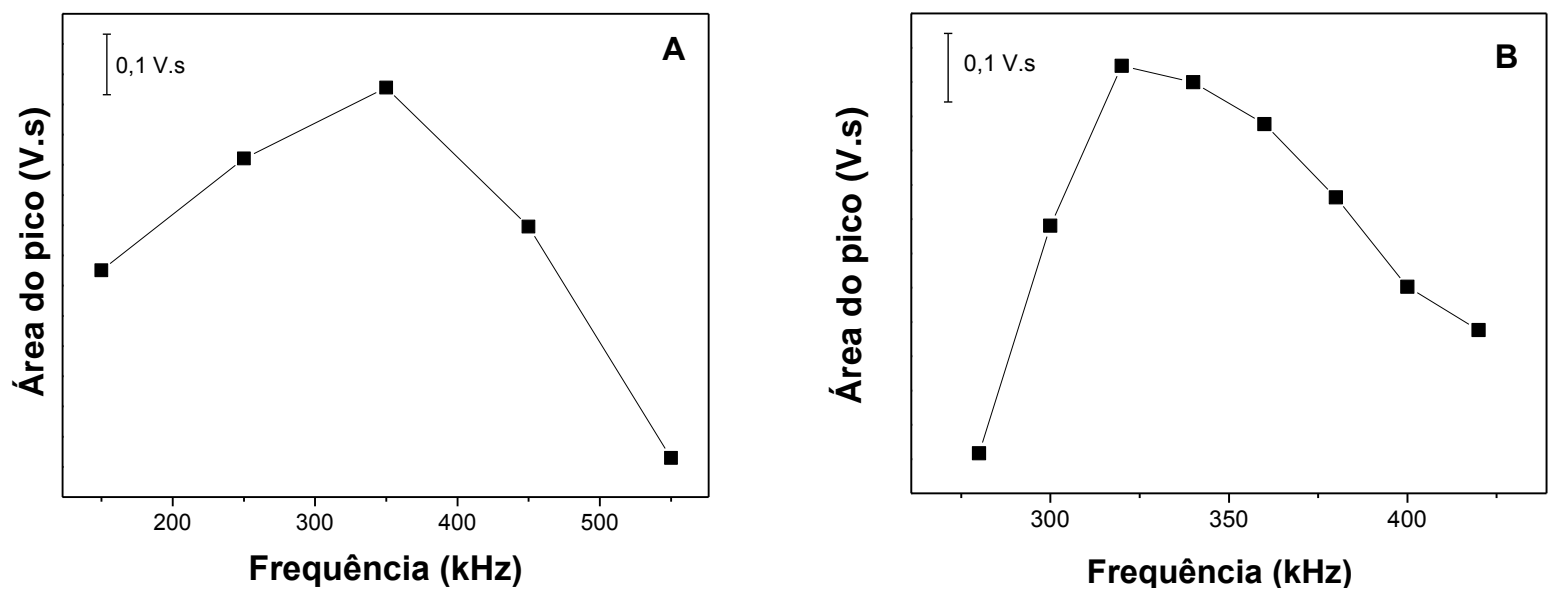

Figura 18. A Figura (A) apresenta um gráfico da área de pico para o glifosato em função da frequência, com uma faixa de estudo variando de 150 a $550 \mathrm{kHz}$. A Figura (B) apresenta um gráfico similar, porem com uma faixa de estudo de frequência menor (de $280 \mathrm{a} 420 \mathrm{kHz}$ ). 
Mantendo-se fixo o valor de frequência em $320 \mathrm{kHz}$, realizou-se um estudo variando-se a amplitude, registrando os eletroferogramas obtidos para uma solução contendo glifosato. Um gráfico apresentando a área do pico para glifosato em função da amplitude é apresentado na Figura 19. A faixa de amplitude avaliada vai de 1,75 a 5,5 $\mathrm{V}_{\mathrm{pp}}$, com intervalos de $0,25 \mathrm{~V}_{\mathrm{pp}}$ de um ponto a outro. Uma melhor resposta foi observada na amplitude de $4,5 \mathrm{~V}_{\mathrm{pp}}$, sendo então usada para estudos subsequentes.

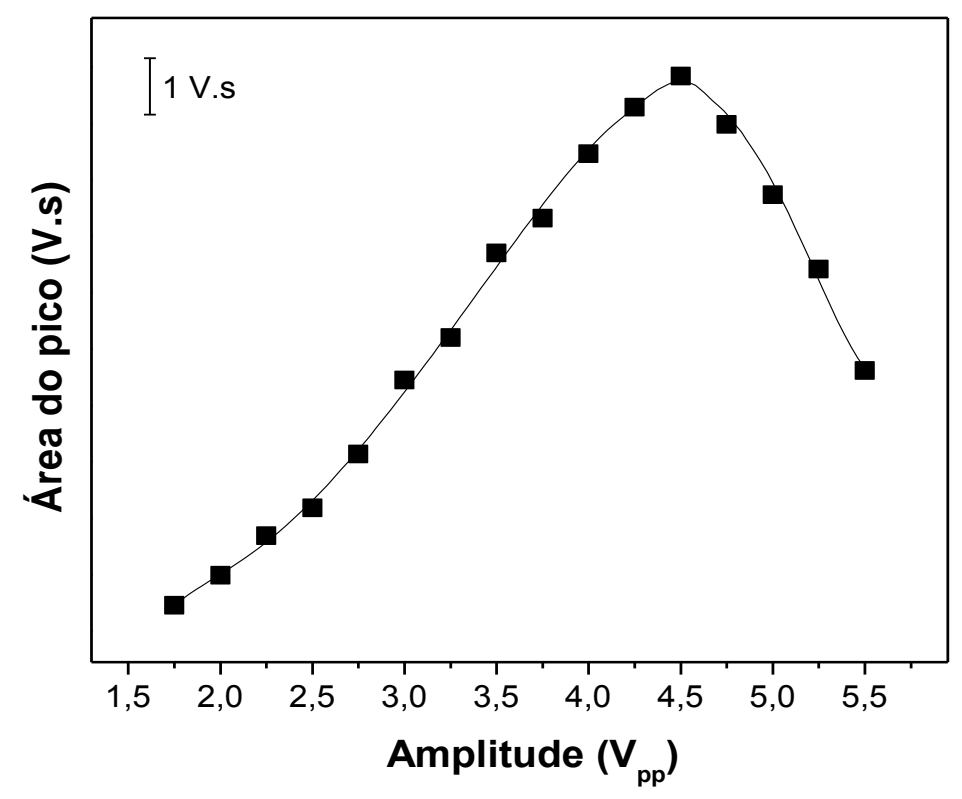

Figura 19. Gráfico apresentando a área do pico para glifosato em função da amplitude.

\subsubsection{Influência do pH e concentração do eletrólito}

$\mathrm{O}$ pH é um parâmetro de extrema importância em eletroforese capilar, ele pode afetar diretamente a qualidade de uma separação. De maneira geral, a variação de $\mathrm{pH}$ tem influência sobre o grau de ionização das espécies, e portanto, na mobilidade efetiva dos analitos em estudo.

O EOF também é afetado pela mudança de $\mathrm{pH}$, onde uma relação diretamente proporcional é encontrada ${ }^{80}$. O baixo valor do EOF $\left(\sim 3,0 \times 10^{-5} \mathrm{~cm}^{2} \mathrm{~V}^{-1} \mathrm{~s}^{-1}\right)$ em microchips de 
PT é conhecido ${ }^{73}$, entretanto, Yu H. et $a l^{81}$ promoveram a separação de dois neurotransmissores manipulando o EOF em microchips desse substrato. Segundo os autores, um pré-tratamento nos canais do microchip com hidróxido de sódio e etanol foi o suficiente para promover um aumento do EOF, e posterior manipulação do mesmo por variação do $\mathrm{pH}$.

Considerando que os analitos estudados neste trabalho migraram contra o EOF eletrosmótico, um aumento deste teoricamente favoreceria o processo de separação desde que a magnitude da mobilidade eletrosmótica não fosse maior que a das mobilidades eletroforéticas. Entretanto um pré-tratamento nos canais não foi necessário, pois uma separação eficiente foi verificada sem uso de tal procedimento.

A faixa de pH avaliada foi de 8,1 a 9,5. A variação do pH não mostrou uma influência significativa na eficiência de separação, onde uma similaridade entre os diferentes eletroferogramas foi verificada. A maior influência foi observada na sensibilidade do sistema, onde um maior valor de área de pico, tanto para glifosato quanto para AMPA, foi encontrado para o pH 8,8 (Figura 20).

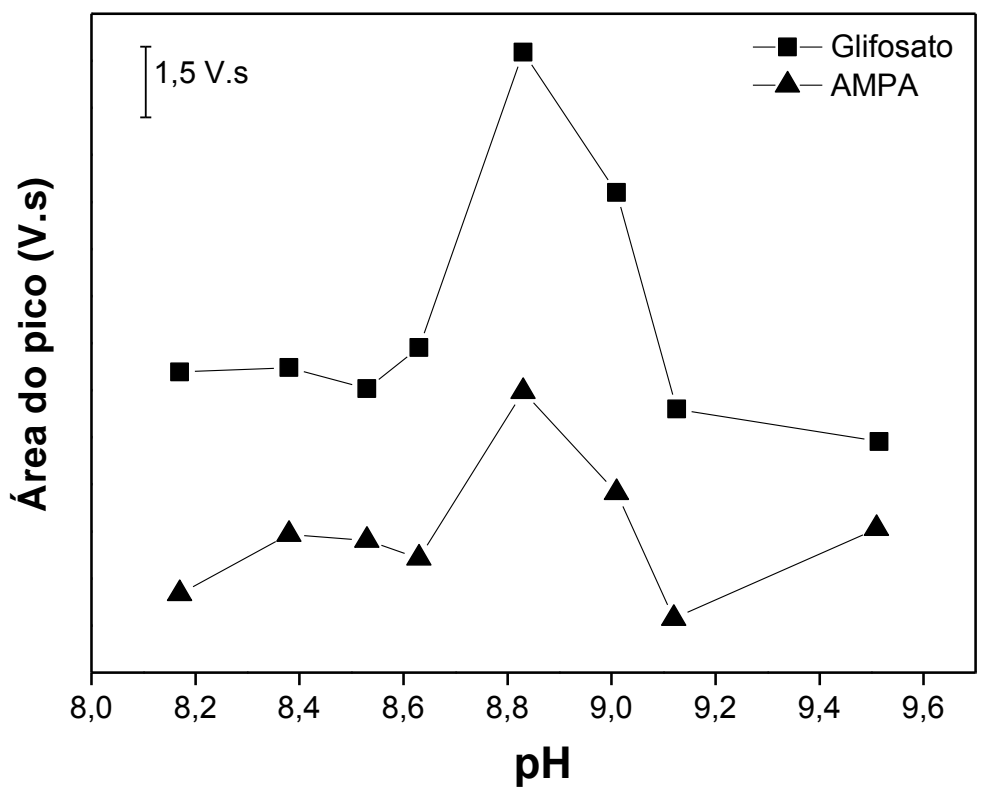

Figura 20. Área do pico para glifosato e AMPA em função do pH. Condições: Tampão CHES/Tris $60 \mathrm{mmol} \mathrm{L}^{-1}$, em diferentes proporções. Condições eletroforéticas: ver Figura 16. Frequência do sinal senoidal para detecção $\mathrm{C}^{4} \mathrm{D}: 320 \mathrm{kHz}$. Amplitude: 4,5 V $\mathrm{pp}$. 
Uma possível explicação para o resultado obtido está relacionada à variação da condutividade do meio com a variação do $\mathrm{pH}$. Nesta etapa do projeto, um eletrólito de trabalho composto foi utilizado; e para se obter um BGE com diferentes pHs a proporção dos componentes do eletrólito foi variada; dessa forma uma mudança na condutividade também é promovida.

Com o auxílio do software PeakMaster $5.2^{82}$, a condutividade para as diferentes proporções do eletrólito foi estimada. A partir dos valores obtidos no software, construiu-se um gráfico com os valores de condutividade em função das diferentes proporções (concentrações) da mistura contida na solução eletrolítica. Para uma melhor compreensão, os dados estão representados em função dos respectivos valores de $\mathrm{pH}$ (Figura 21). Verificou-se que o maior valor de condutividade é encontrado na proporção relacionada ao $\mathrm{pH}$ 8,83 (30 $\mathrm{mmol} \mathrm{L}^{-1}$ de CHES e $30 \mathrm{mmol} \mathrm{L}^{-1}$ de Tris); justamente onde um maior valor de área de pico, para ambos analitos de estudo, é observado (ver Figura 20). A suposta relação entre os resultados obtidos e a condutividade do meio fica clara quando lembrado que, na detecção $C^{4} \mathrm{D}$ a resposta do detector esta relacionada com a diferença de condutividade entre o eletrólito de trabalho e a zona da amostra que migra no capilar.

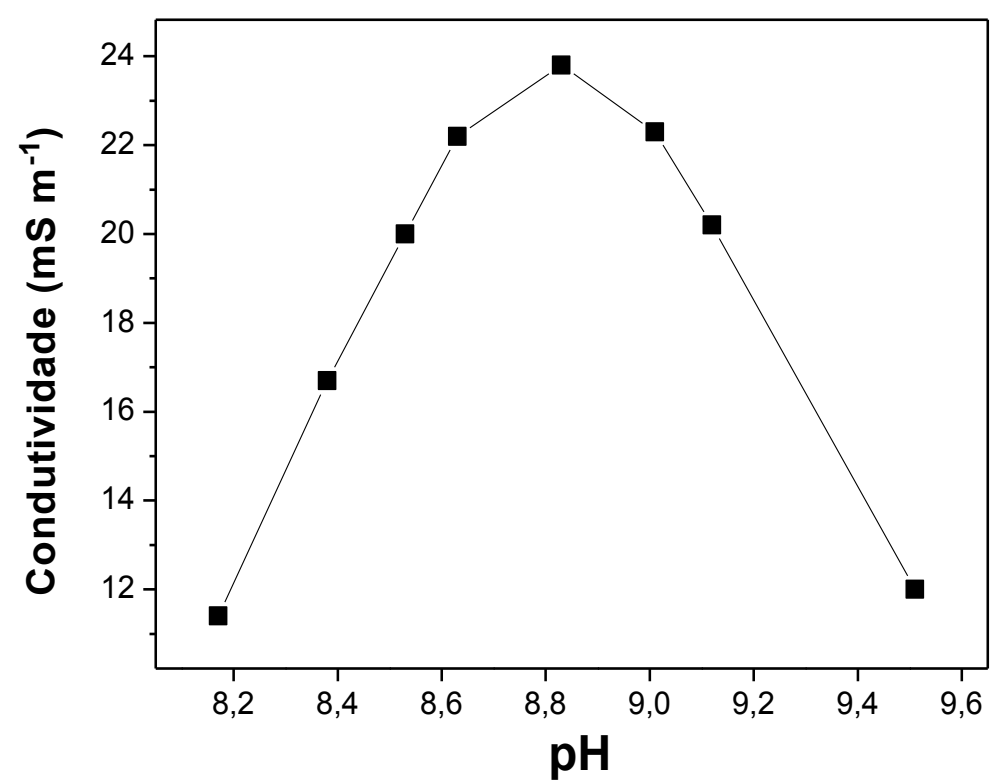

Figura 21. Gráfico do valor de condutividade do eletrólito de trabalho em função do pH. 
Mantendo-se a proporção de CHES/Tris relacionada ao $\mathrm{pH}$ em que uma maior sensibilidade foi obtida, a influência da concentração do eletrólito sobre a resposta do sistema foi investigada. A faixa de concentração avaliada foi de 20 a $120 \mathrm{mmol} \mathrm{L}^{-1}$. A Figura 22 apresenta o gráfico das áreas para glifosato e AMPA em função da concentração do eletrólito. Até a concentração $80 \mathrm{mmol} \mathrm{L}{ }^{-1}$, observa-se um aumento gradativo das áreas de pico para ambos analitos, com posterior decaimento. Para concentrações acima desse valor, verificou-se um acentuado ruído na linha base, tanto quanto distorções nos picos dos analitos em estudo. Assim sendo, a concentração de $80 \mathrm{mmol} \mathrm{L}^{-1}$ foi escolhida para a continuidade dos estudos.

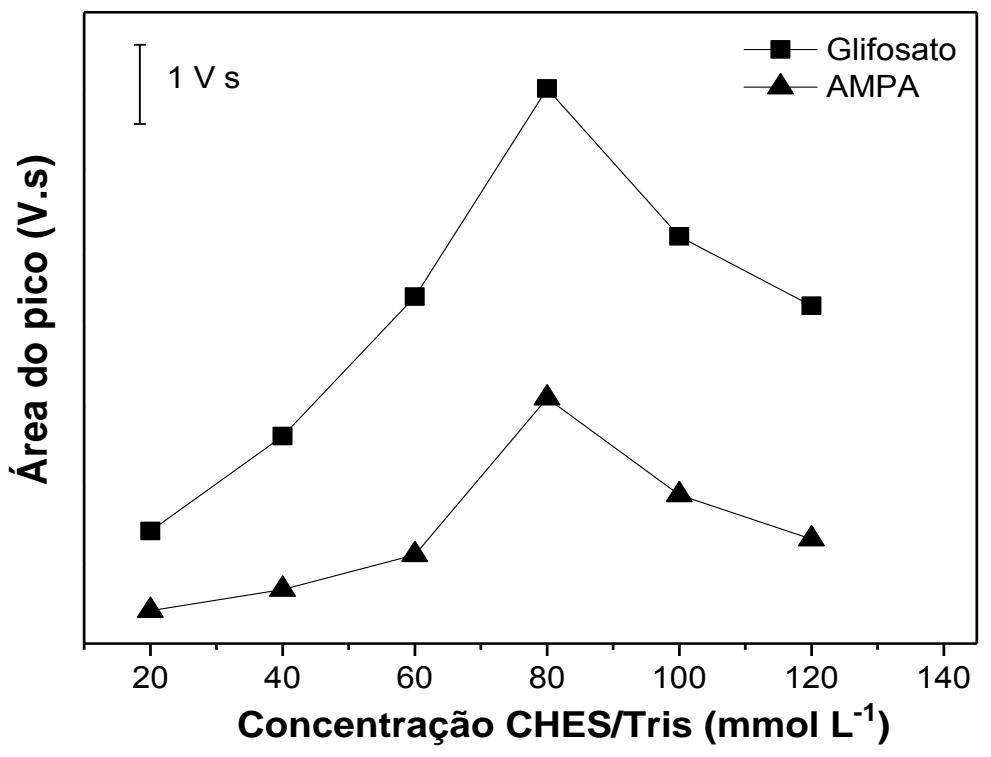

Figura 22. Dependência das áreas de pico para glifosato e AMPA, com a variação da concentração do eletrólito CHES/Tris. Outras condições vide Figura 20.

\subsubsection{Determinação do Tempo de Injeção da Amostra}

Foi realizada uma variação do tempo de injeção da amostra, e verificada a influência de tal procedimento sobre a resposta eletroforética do sistema. As amostras foram injetadas eletrocineticamente no canal sob aplicação de $1,0 \mathrm{kV}$ variando o tempo de 4 a 9 s. No estudo verificou-se que tempos maiores que sete segundos de injeção, promoveram eletroferogramas 
com baixa resolução entre os picos. Basicamente o tempo de injeção determina a quantidade de amostra injetada; e assim sendo, altos tempos de injeção podem gerar picos com grande alargamento de banda.

Buscando um compromisso entre resolução e sensibilidade, o tempo de $7 \mathrm{~s}$ foi escolhido como melhor valor. Os valores de intensidade e largura do pico para glifosato foram graficados em função do tempo de injeção e estão apresentados nas Figuras 23. Para tempos menores que 7 s observam-se baixos valores de intensidade de sinal, e como comentado, para tempos maiores a separação é prejudicada.
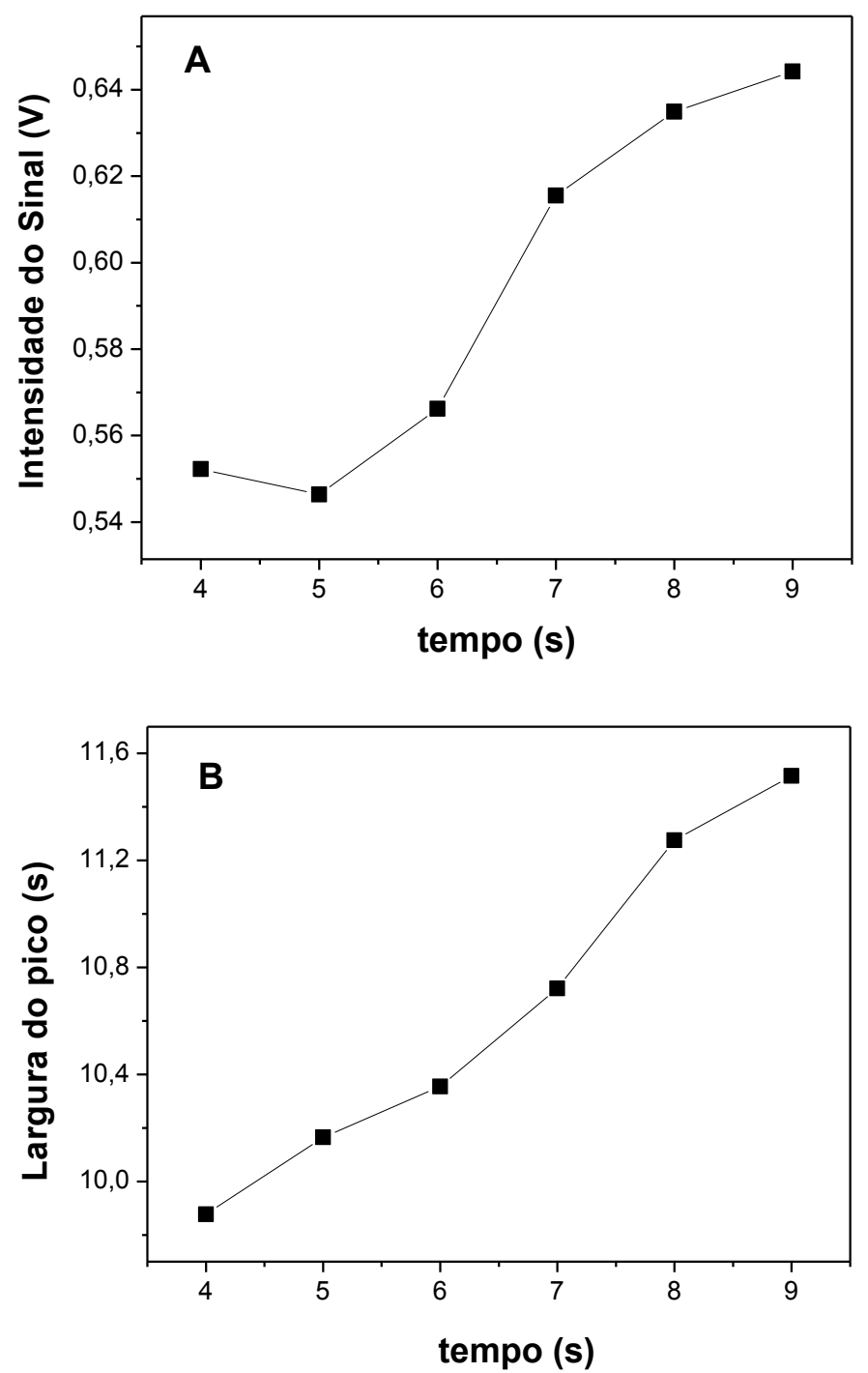

Figura 23. Gráfico da intensidade do sinal para glifosato em função do tempo de injeção (A). Gráfico da largura do pico para glifosato em função do tempo de injeção (B). 


\subsubsection{Influência do potencial de separação e gráfico de Ohm}

A influência que a variação do potencial de separação causa no tempo de migração dos analitos é apresentada na Figura 24. Observa-se que com o aumento do potencial de separação há um decréscimo no tempo de migração dos analitos, tanto quanto uma diminuição nas larguras dos picos para glifosato e para AMPA. A diminuição das larguras dos picos esta relacionada ao menor tempo em que o zona da amostra permanece no canal de separação, pois dessa forma os processos de difusão da amostra são minimizados.

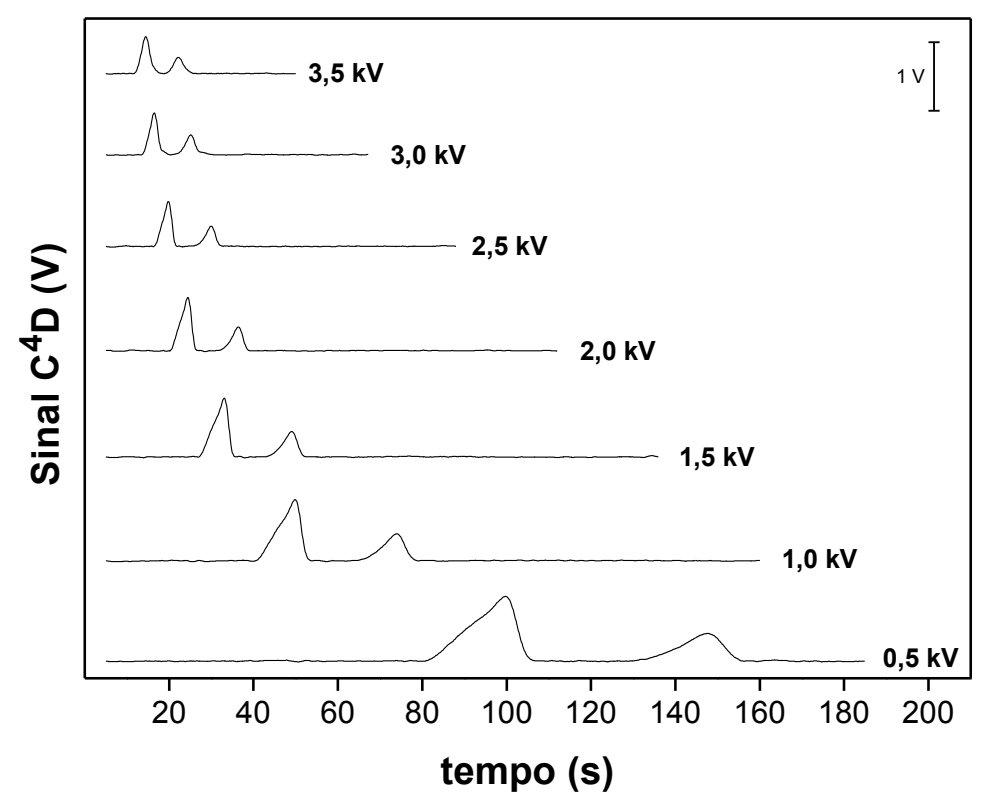

Figura 24. Efeito do potencial de separação no tempo de migração dos analitos.

De um modo geral, menores tempos de migração são idealizados a fim de se diminuir o tempo total de uma análise eletroforética, fato que pode ser obtido com o aumento do potencial de separação. No entanto, a corrente elétrica gerada com o aumento do potencial pode provocar o aquecimento do canal em decorrência da perda de eficiência na dissipação de calor (efeito Joule). Por este motivo, de modo a garantir a dissipação eficiente de calor, deve- 
se realizar as separações eletroforéticas em um limite de potencial onde não ocorra tal fenômeno. Microchips de PT são plataformas microfluídas que possuem como característica uma boa dissipação de calor quando comparadas a outros substratos ${ }^{83}$, entretanto algumas propriedades do BGE também influenciam na formação de um gradiente de temperatura dentro dos canais. Assim sendo, a capacidade de dissipar calor do microchip de PT foi investigada com base na lei de $\mathrm{Ohm}^{84}$, utilizando os parâmetros analíticos previamente otimizados e descritos anteriormente. Para isso, o microcanal de separação foi inicialmente preenchido com o eletrólito de trabalho (CHES/Tris, 40/40 mmol L ${ }^{-1}$, pH 8,8) e uma diferença de potencial foi aplicada ao microcanal. A corrente eletroforética resultante foi medida em função dos valores de potenciais aplicados; a Figura 25 apresenta a relação encontrada.

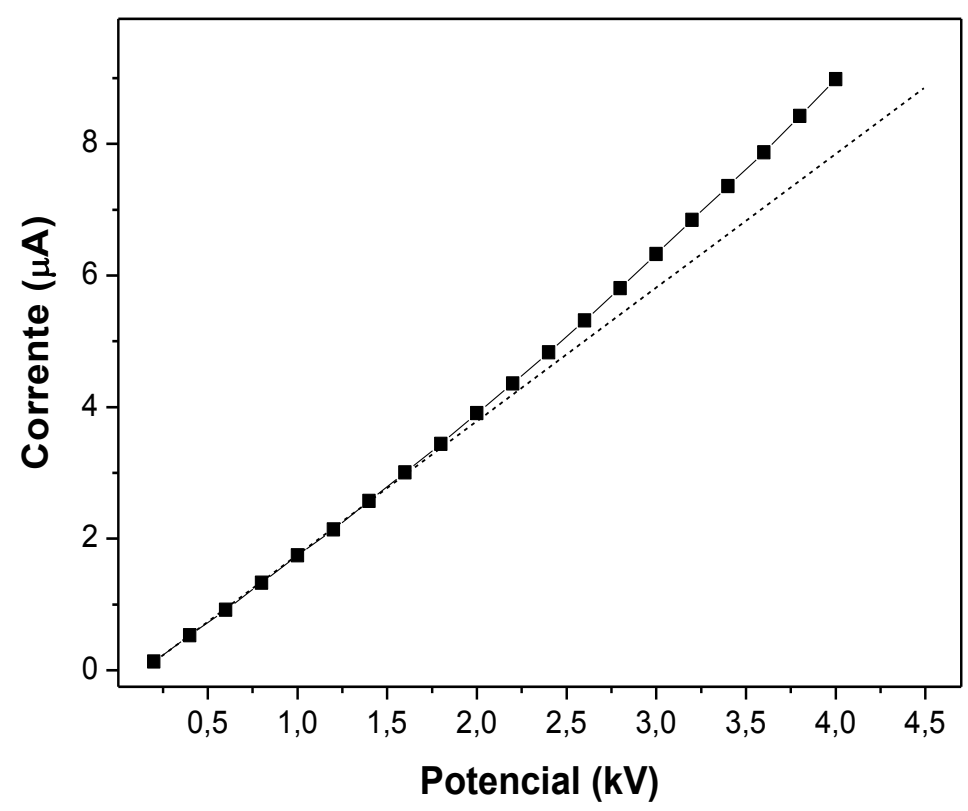

Figura 25. Curva obtida para a corrente eletroforética em função do potencial aplicado. Comprimento do canal: $5 \mathrm{~cm}$.

Como observado na Figura 25, uma relação linear entre a corrente eletroforética e o potencial elétrico aplicado é encontrada até $1,5 \mathrm{kV}$. Esse resultado demonstra que até esse 
potencial uma dissipação eficiente de calor ocorre, portanto deve ser utilizado como valor limite de potencial de trabalho.

\subsubsection{Repetibilidade intra e inter chip}

A repetibilidade do método foi avaliada com base nos coeficientes de variação $(\mathrm{CV})$ em termos das áreas dos picos eletroforéticos para repetições sucessivas utilizando o mesmo chip e os mesmos eletrodos (intra-chip), e também utilizando diferentes chips com diferentes eletrodos (inter-chip). Para verificação da repetibilidade intra-chips sete injeções foram realizadas sequencialmente, a Figura 26 apresenta os eletroferogramas obtidos.

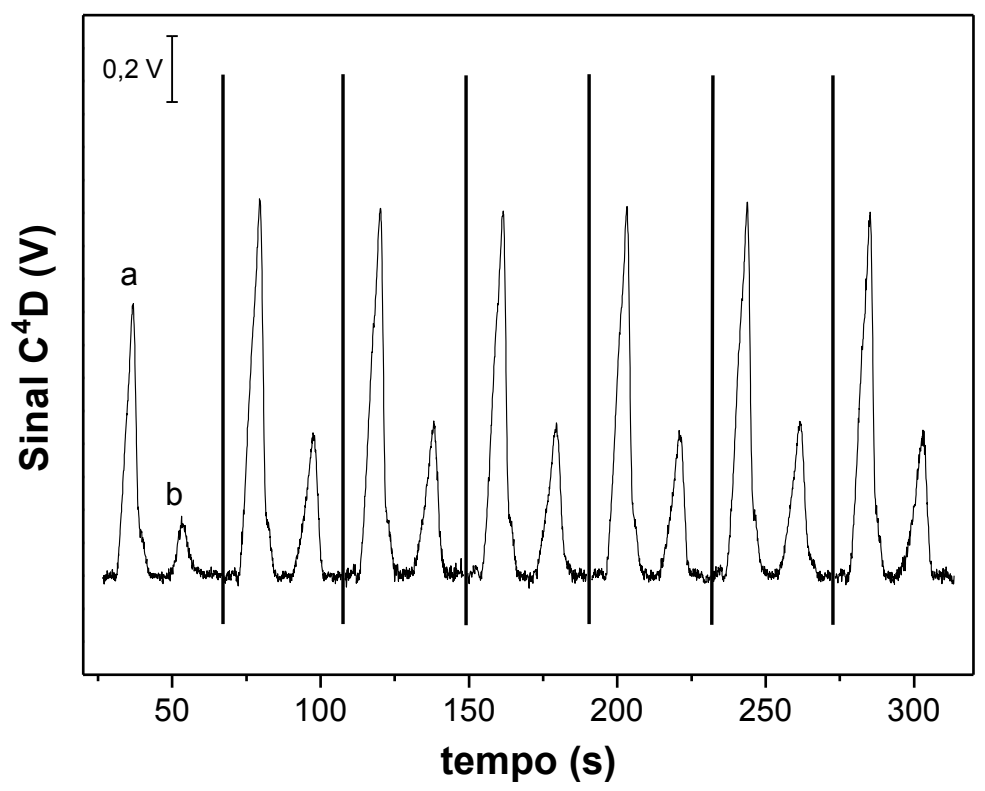

Figura 26. Sequência de sete eletroferogramas obtidos para a separação de glifosato (a) e AMPA (b), ambos com concentração de $2 \mathrm{mmol} \mathrm{L}^{-1}$. Condições: Eletrólito CHES/Tris a $80 \mathrm{mmol} \mathrm{L}^{-1}$, pH 8,8 . Injeção: $-1,0 \mathrm{kV} / 7 \mathrm{~s}$; potencial de separação: $-1,5 \mathrm{kV}$. Frequência do sinal senoidal para detecção $\mathrm{C}^{4} \mathrm{D}$ : $320 \mathrm{kHz}$. Amplitude: 4,5 $\mathrm{V}_{\mathrm{pp}}$. 
Para os tempos de migração um CV de 1,6 e 1,9\% foi observado para glifosato e AMPA respectivamente. Nas áreas do pico, os valores de CV (ou desvio padrão relativo RSD $)^{85}$ das sete injeções consecutivas foram $9,1 \%$ para o glifosato e $22,1 \%$ para o AMPA. Como observado na Figura 26, a primeira injeção resultou em picos de menor intensidade quando comparada com as demais injeções. Esse efeito pode ser atribuído ao fato de que os analitos em estudo migram contra o EOF, dessa forma para um efetivo transporte eletrocinético das espécies e preenchimento total do canal de amostragem, um maior tempo é requerido $^{83}$. Desconsiderando a primeira injeção, os valores de CV para as áreas do pico caem para $1,5 \%$ e $3,3 \%$ para glifosato e AMPA respectivamente. Uma ferramenta estatística simples também pode ser usada para justificar o não uso dos valores de área da primeira injeção para o calculo de $\mathrm{CV}$, essa ferramenta é conhecida como Teste $Q$ de Dixon $^{86}$. Basicamente trata-se de uma equação que verifica se um dado valor analítico é muito discrepante dos demais valores de um conjunto, e deve ou não, ser considerado.

$$
Q=\frac{\mid \text { valor }_{\text {suspeito }}-\text { valor }_{\text {vizinho }} \mid}{\text { valor }_{\text {maior }}-\text { valor }_{\text {menor }}}
$$

Se o valor calculado de $Q$ exceder um valor crítico tabelado, o valor suspeito deve ser rejeitado. Utilizando a Equação 10, os valores de $Q$ calculados, para os dados da Figura 26, foram de 0,916 e 0,874 para glifosato e AMPA respectivamente, tendo os valores de área da primeira injeção como suspeitos. Para um conjunto de sete amostras e com base na Tabela 6, os valores suspeitos podem ser desconsiderados (com um limite de confiança de 95\%) pois não fazem parte, de acordo com o teste $Q$, do conjunto de valores. 
Tabela 6. Valores críticos de $Q$ para um teste bi-caudal ${ }^{*}$, com limite de confiança de $95 \%$.

\begin{tabular}{cc} 
Tamanho da amostra & Valor crítico \\
\hline 4 & 0,831 \\
5 & 0,717 \\
6 & 0,621 \\
7 & 0,570 \\
8 & 0,524 \\
9 & 0,492 \\
10 & 0,464 \\
\hline
\end{tabular}

A repetibilidade entre diferentes chips (inter-chips) foi verificada utilizando três chips distintos, com seus respectivos eletrodos para detecção $C^{4} D$. Os eletroferogramas obtidos para os diferentes chips são apresentados na Figura 27. Os valores de CV foram 10,1\% para o glifosato e 8,6\% para o AMPA nas áreas do pico; e para os tempos de migração do glifosato foi encontrado um valor de CV de 1,4\%. Diversos parâmetros a cerca das técnicas utilizadas podem afetar diretamente a reprodutibilidade do método desenvolvido. A presença de erros aleatórios, inerentes a qualquer medida analítica, também comprometem a confiabilidade dos resultados obtidos. Entretanto, mesmo com a somatória dos diversos fatores que influenciam no calculo de CV, pode-se afirmar que com uma relativa habilidade na confecção dos chips, tanto quanto no recorte e alinhamento dos eletrodos, bons resultados de reprodutibilidade podem ser alcançados.

\footnotetext{
*testes bi-caudais são apropriados quando não se conhece em que extremo um valor suspeito pode ocorrer. Ou seja, o analista não tem qualquer ideia pré-concebida, antes dos resultados experimentais, se uma diferença significante eventual entre as médias experimentais e o valor suspeito será positiva ou negativa.
} 


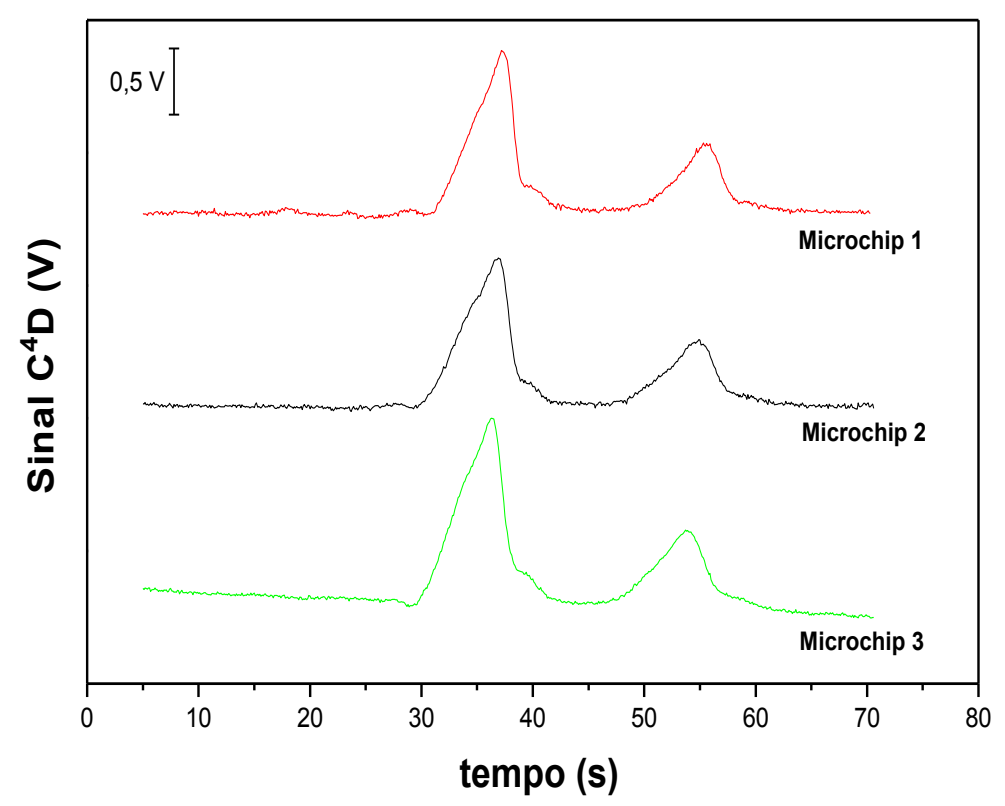

Figura 27. Eletroferogramas obtidos para três diferentes chips. Ambos analitos com concentração de $2 \mathrm{mmol} \mathrm{L}^{-1}$.

O desempenho da separação eletroforética realizada nos microdispositivos fabricados em PT foi verificada em termos de números de pratos teóricos $(N)$. A eficiência foi calculada de acordo com a Equação $N=5,54\left(\mathrm{t} / \mathrm{w}_{1 / 2}\right)^{2}$, apresentada na seção 1.3. Os valores de eficiência encontrados para glifosato e AMPA foram 331 e 772 respectivamente. Uma relação direta entre eficiência e tempo de migração é observada na Equação, onde menores tempos de migração geram baixos valores de eficiência. Os baixos valores de $N$ encontrados para os dispositivos de PT podem também ter sofrido influência de efeitos relacionados a difusão e à alta rugosidade do toner (que define as paredes dos microcanais) ${ }^{74}$.

\subsubsection{Curva analítica e limites de detecção}

A Figura 28 apresenta eletroferogramas obtidos para misturas contendo níveis de concentrações crescentes de (a) glifosato e (b) AMPA, em incrementos de $150 \mu \mathrm{mol} \mathrm{L}^{-1}$ para 
a faixa de concentrações entre 150 e $900 \mu \mathrm{mol} \mathrm{L}{ }^{-1}$. No detalhe da figura são apresentadas as curvas de calibração, com coeficientes de correlação linear de 0,9979 e 0,9968 para glifosato e AMPA, respectivamente. Cada ponto nas curvas é um valor médio de três medidas, sendo que para se conseguir uma correlação linear, os microcanais foram lavados com solução tampão durante $100 \mathrm{~s}$ antes de cada injeção.

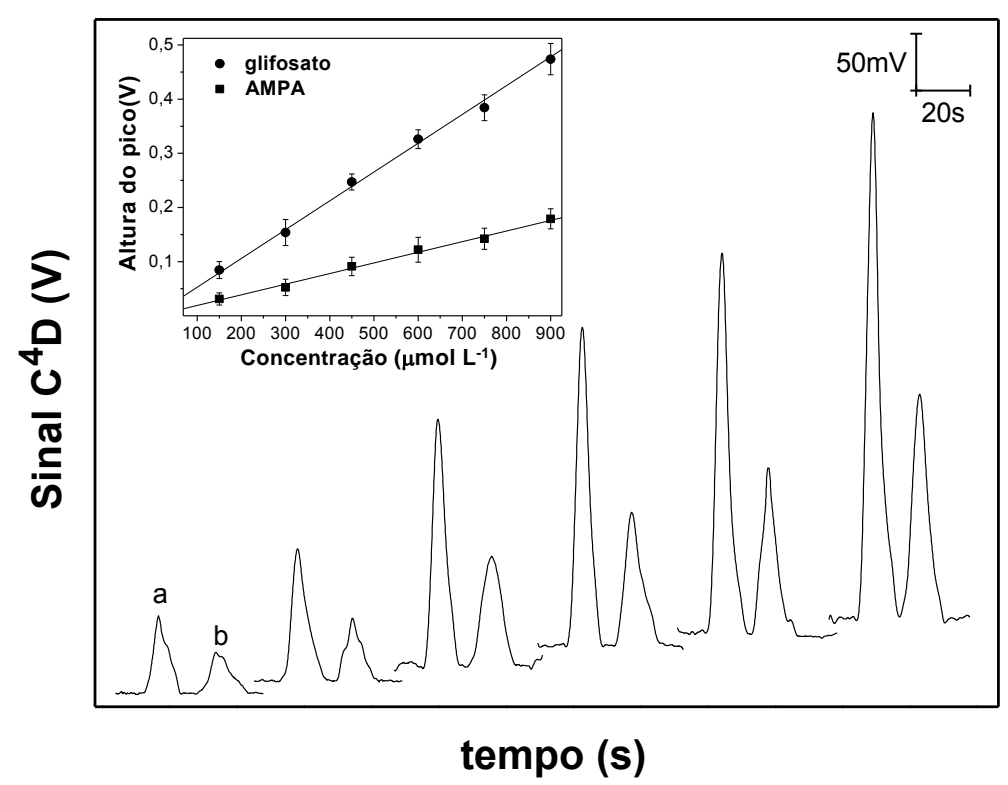

Figura 28. Eletroferogramas obtidos para misturas contendo concentrações crescentes de (a) glifosato e (b) AMPA, em incrementos de $150 \mu \mathrm{mol} \mathrm{L}^{-1}$. No detalhe estão apresentadas as curvas de calibração no intervalo de concentrações entre 150 e $900 \mu \mathrm{mol} \mathrm{L}^{-1}$.

Duas maneiras distintas foram utilizadas para calcular os valores de limite de detecção (LD). Uma delas trata-se da diluição em série da solução padrão, até obtenção de um eletroferograma com relação sinal/ruído igual a 3. Através desse método os valores de LD encontrados para glifosato e AMPA foram de 45,1 e 70,5 $\mu \mathrm{mol} \mathrm{L} \mathrm{L}^{-1}$ respectivamente.

A interpretação equivocada da amplitude do ruído da linha de base pode resultar em valores errôneos de LD. Considerando esse fato, um segundo método para determinação de LD é apresentado. Com base em parâmetros da curva analítica, como desvio padrão do 
intercepto da reta, o segundo método apresenta maior confiabilidade estatística. Os valores encontrados de LD a partir de parâmetros da regressão linear foram de 60,8 e 74,8 $\mu$ mol L $\mathrm{L}^{-1}$ para glifosato e AMPA respectivamente. A Equação 11 mostra de que forma os valores de limite de detecção foram calculados a partir desse método ${ }^{86}$.

$$
L D=3 S D / b
$$

sendo SD = desvio padrão do intercepto da curva, e $\mathbf{b}=$ coeficiente angular da curva.

Tomando os valores de LD calculados a partir dos parâmetros da curva analítica, verifica-se que a metodologia desenvolvida não forneceu um limite de detecção adequado para a análise de glifosato que atenda à legislação brasileira ${ }^{43,87}$. Com o intuito de se diminuir os valores de LD, a técnica de sample stacking foi utilizada. Trata-se de uma préconcentração da amostra on-line, em que não há a necessidade de alteração na instrumentação presente. Resume-se na manipulação da força iônica da amostra e do tampão, onde uma condutividade mais baixa na região da amostra promove um aumento do campo elétrico e consequente aumento na velocidade dos íons ali presentes; quando essa região entra em contato com uma região de mais alta condutividade (eletrólito de corrida) há uma desaceleração na zona da amostra promovendo assim uma região com maior concentração que a original $^{88}$. Após a aplicação dessa técnica problemas de repetibilidade foram encontrados; aparentemente associados à dificuldade de limpeza dos microcanais entre uma injeção e outra, dessa forma a estratégia foi então descartada.

A resposta em $C^{4} D$ está intimamente relacionada a parâmetros associados às celas de detecção como: posicionamento e modelagem dos eletrodos, espessura do dielétrico, e distância entre os eletrodos ${ }^{89,90}$. Fundamentando-se nisso, alguns estudos visando a diminuição dos valores de limites de detecção são encontrados na literatura ${ }^{91-93}$. Ainda 
objetivando melhorias na sensibilidade, encontra-se na litereatura trabalhos utilizando detecção condutométrica híbrida, na qual o eletrodo de excitação é mantido em contato com o eletrólito $^{94}$. Com base nas alternativas citadas acima, estudos visando uma melhora na sensibilidade podem ser realizados. Assim sendo, tais estratégias ficam como proposta de trabalhos futuros.

\subsubsection{Aplicação em amostra real}

Depois de escolhidas as melhores condição de separação e de detecção, aplicou-se esta metodologia para a determinação de glifosato e AMPA em águas naturais. Utilizando amostras de água de um córrego local da cidade de São Carlos, a aplicabilidade do método apresentou resultados satisfatórios em relação a valores de recuperação, pois se enquadram na faixa recomendada para pesticidas (entre 70 e $120 \%)^{95}$. Não foi necessária qualquer etapa de extração ou limpeza da amostra.

A Figura 29 apresenta os eletroferogramas da amostra fortificada com $1 \mathrm{mmol} \mathrm{L}^{-1}$ dos analitos em estudo ( $i$ ), e da amostra sem fortificação ( $i i$ ). Observa-se a presença de um composto desconhecido, com um pico eletroforético contendo uma área inferior aos compostos de estudo, tendo um tempo de retenção de aproximadamente 21 s. Os valores de recuperação obtidos para glifosato e AMPA foram de 87,4\% e 83,7 respectivamente; onde para o cálculo de recuperação, amostras diluídas para $0,5 \mathrm{mmol} \mathrm{L}^{-1}$ de ambos analitos foram utilizadas. 


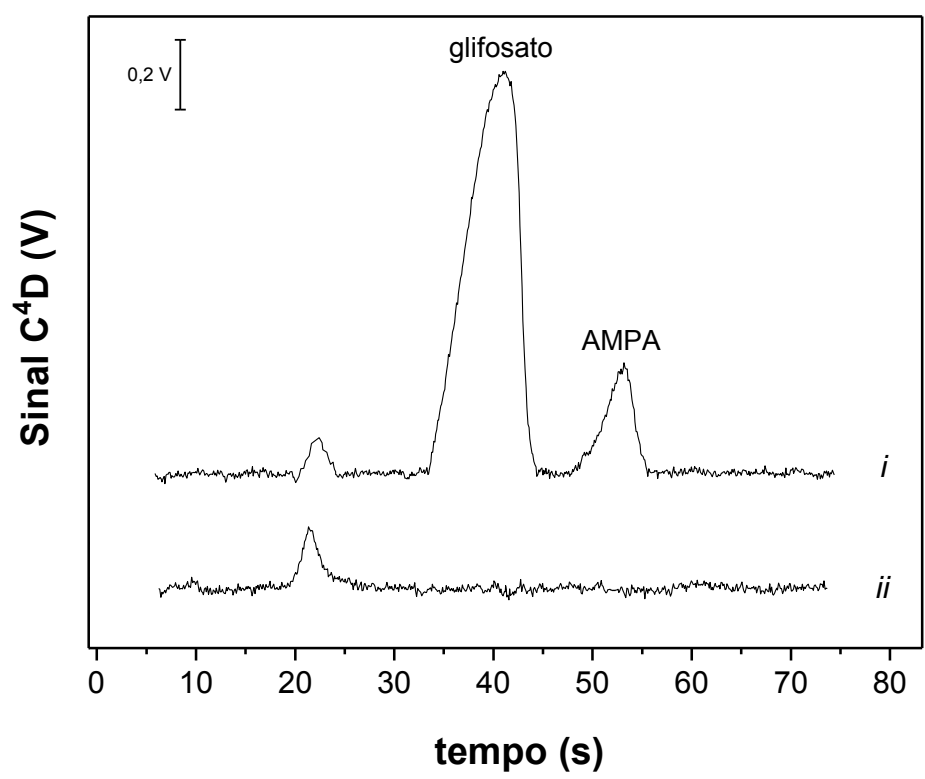

Figura 29. Eletroferograma de uma amostra de água natural fortificada com glifosato e AMPA ambos a $1 \mathrm{mmol} \mathrm{L}^{-1}(i)$. Eletroferograma da amostra de água natural sem fortificação ( ii ). Outras condições vide Figura 26.

\subsubsection{Conclusão}

Os microdispositivos de PT apresentaram performance analítica satisfatória quando avaliados em termos de separação eletroforética para as moléculas de glifosato e AMPA. Separações com picos bem definidos e boa resolução foram verificadas.

Dentre as inúmeras metodologias encontradas para a determinação do herbicida glifosato, possivelmente o método desenvolvido neste capitulo se encontra entre os mais simples e de menor custo agregado. A simplicidade de instrumentação e a facilidade de confecção dos microdispositivos confirmam tal afirmação.

O método proposto apresentou aplicabilidade satisfatória em amostras de interesse ambiental, tanto quanto boa repetibilidade intra e inter-chips. Apresenta como maior desvantagem um valor de LD relativamente alto para glifosato, não se enquadrando nas exigências estipuladas pela legislação brasileira. Entretanto, adaptações instrumentais simples a cerca do sistema de detecção encorajam o autor a contornar tal problema em trabalhos 
futuros; viabilizando a total aplicabilidade do método desenvolvido em amostras de interesse ambiental. 


\section{DETECÇÃO DE GLIFOSATO POR CRONOAMPEROMETRIA}

Buscando melhores valores de LD, a técnica de cronoamperometria foi utilizada como sistema de detecção. De maneira geral, esse sistema de detecção apresenta maior sensibilidade quando comparada a $\mathrm{C}^{4} \mathrm{D}{ }^{96}$. Nesse capítulo será apresentado um estudo eletroquímico verificando a potencialidade de eletrodos de cobre e ouro como sensores amperómetricos para glifosato. Utilizando o eletrodo no qual a maior sensibilidade foi observada, e após acoplamento no sistema eletroforético ainda utilizando microchips de PT, realizou-se então a determinação simultânea de glifosato e AMPA.

\subsection{Introdução}

Os pequenos volumes de amostra resultantes das separações em microdispositivos (< que 500pL), exigem o emprego de detectores extremamente sensíveis. Vários sistemas de detecção que suprem essa necessidade em microdispositivos são utilizados com sucesso, dentre eles LIF (fluorescência induzida a laser) ${ }^{97}$, espectrometria de massas ${ }^{98}$, quimiluminescência $^{99}$ e eletroquimiluminescência ${ }^{100}$, dentre outros.

Com o crescimento do interesse da comunidade cientifica para com microdispositivos eletroforéticos, sistemas de detecção que atendam as necessidades de sensibilidade são gradativamente mais estudadas. Atendendo a exigência de alta sensibilidade, a detecção eletroquímica em microdispositivos foi usada pela primeira vez por Woolley e colaboradores em $1998^{101}$, data relativamente recente quando considerado o emprego da maioria dos detectores de alta sensibilidade em microssistemas.

A alta compatibilidade com a tecnologia de microfabricação torna a detecção eletroquímica extremamente atrativa para aplicação em microdispositivos, possibilitando a 
construção de um sistema totalmente integrado. Considerando a possibilidade de miniaturização de fontes de energia e potenciostatos ${ }^{102}$, a detecção eletroquímica é a que mais tem potencial para construção de um microdispositivo analítico completo.

Detecção eletroquímica é um termo corriqueiramente utilizado para fazer referencia a três principias modos de detecção: condutometria, potenciometria e amperometria. Entre esses modos de detecção eletroquímica, a amperometria é mais extensivamente usada em microdispositivos, salvo a detecção condutometrica que vem ganhando espaço entre os pesquisadores, onde seu modo sem contato já foi comentado anteriormente nesse documento.

Basicamente, a detecção amperométrica é executada através da medida de corrente, em função do tempo, resultante da aplicação de um potencial constante no eletrodo de trabalho de uma célula eletroquímica acoplada ao microdispositivo. Essa célula eletroquímica pode ter a configuração convencional de três eletrodos, com a presença dos eletrodos de referência e auxiliar, ou dois eletrodos quando somente o de trabalho e o auxiliar a compõe ${ }^{103}$. A aplicação do potencial no eletrodo de trabalho promove a oxidação ou redução das espécies químicas, com as respostas de corrente obtidas nesses processos redox sendo proporcionais à concentração do analito.

Uma das dificuldades encontradas no emprego da amperometria associada à eletroforese capilar é o campo elétrico aplicado para promover a separação dos analitos, o qual pode causar sérias interferências na detecção. Quando um eletrodo é posicionado muito próximo do final do capilar, o intenso campo elétrico gera um ruído significativo o que pode reduzir sensivelmente o limite de detecção ${ }^{104}$. Existe neste caso, um compromisso entre proximidade do eletrodo do final do capilar, ruído gerado pelo campo elétrico e a resolução entre os picos, pois quanto mais afastado o eletrodo estiver do capilar, maior o alargamento deste sinal transiente. 
Para contornar o problema de interferência causada pelo campo elétrico do sistema eletroforético, várias configurações de célula foram propostas para esse tipo de detecção. Assim, o posicionamento do eletrodo de trabalho pode ser feito de três maneiras diferentes: na saída do microcanal de separação ("end-channel”), no interior do microcanal de separação ("in-channel") e no interior do microcanal mas fora do campo elétrico da separação eletroforética ("off-channel”). No posicionamento na saída do microcanal de separação ("end-channel") existem ainda dois modos: com o eletrodo integrado no microdispositivo ("on-chip") e fora do microdispositivo (“off-chip") ${ }^{105,106}$. A Figura 30 apresenta o desenho esquemático de cada uma dessas configurações de alinhamento do eletrodo de trabalho no microcanal de separação.

Dentre as diferentes possibilidades de configuração usada no acoplamento entre eletroforese em microdispositivos e detecção amperométrica, a configuração com posicionamento no final do canal ("end-chanel”) é a mais usada ${ }^{107}$. Nesse modo, o eletrodo de trabalho é posicionado a algumas dezenas de micrometros do final do canal de separação, ficando quase que efetivamente isolado do potencial aplicado na separação eletroforética. Quando comparado às outras configurações, a detecção no modo end-chanel é a que apresenta os maiores valores de limite de detecção e separações menos eficientes ${ }^{108}$. Esse fato ocorre devido à difusão dos analitos no espaço existente entre eletrodo e o final do microcanal de separação (Figura 30A e 30B). Em contra partida, o posicionamento do eletrodo muito próximo ao fim do microcanal pode causar grandes ruídos na detecção, acarretando em perdas de sensibilidade. 


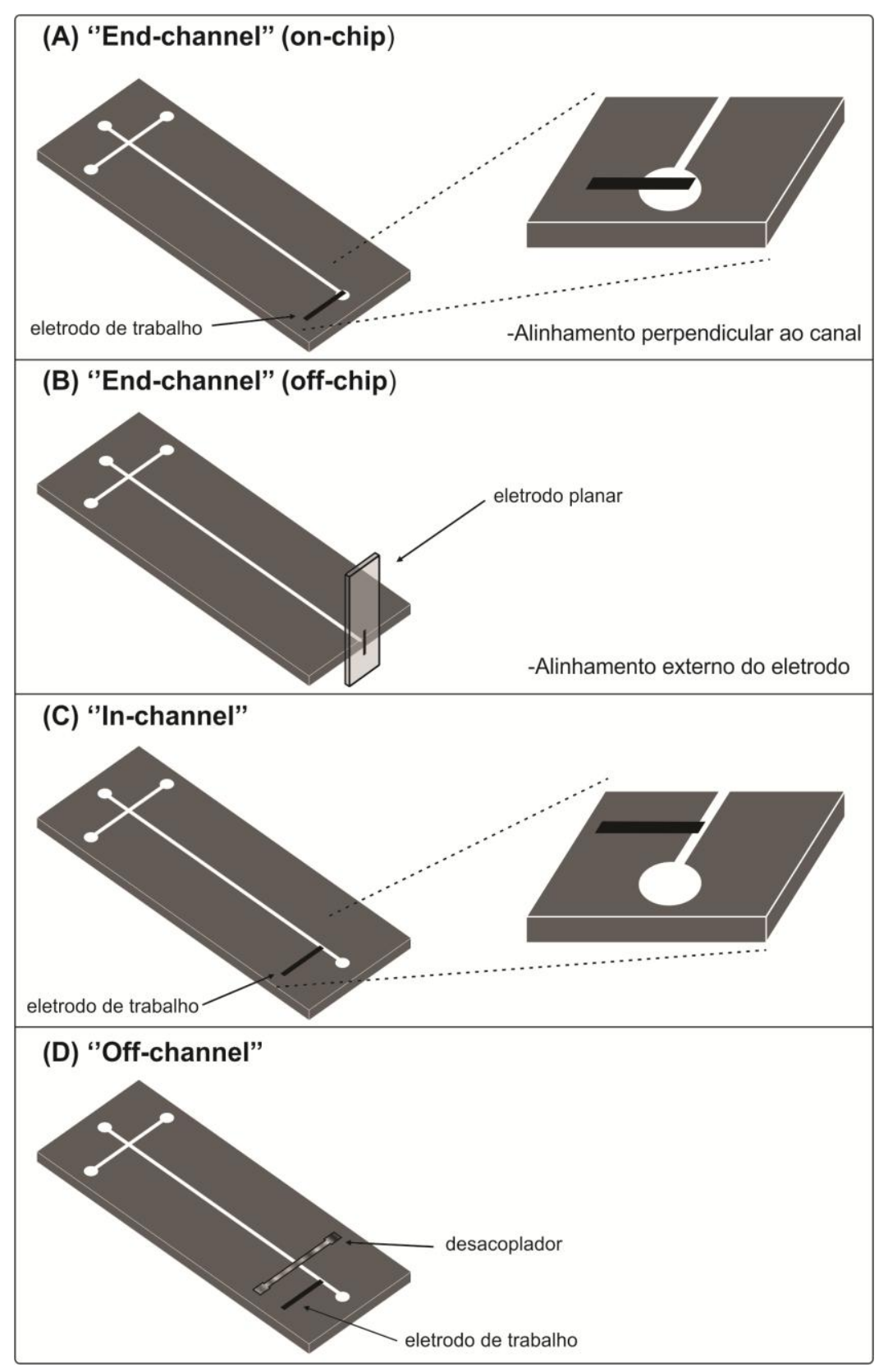

Figura 30. Desenho esquemático das possíveis configurações de alinhamento do eletrodo de trabalho no microcanal de separação. (A) Eletrodo na saída do microcanal ("end-channel") e integrado no próprio dispositivo ("on-chip"), (B) eletrodo na saída do microcanal ("end-channel") e fora do dispositivo ("off-chip"), (C) eletrodo no interior do microcanal ("in-channel") e (D) eletrodo no interior do microcanal mas fora do campo elétrico da separação eletroforética ("off-channel").

O modo de separação "in-channel” surgiu com o intuito de minimizar os problemas relacionados ao alargamento de banda, devido à difusão dos analitos após deixar o fim do microcanal. Como os analitos separados por eletroforese permanecem confinados no interior 
do microcanal de separação no momento em que atingem o eletrodo de trabalho (Figura 30C), os problemas de alargamento de banda são minimizados nessa configuração ${ }^{109}$. Entretanto potenciostatos mais elaborados devem ser usados para se contornar problemas de isolamento.

O modo de detecção "off-channel" também foi desenvolvido para superar os problemas relacionados ao alargamento de banda observado no modo "end-channel". O posicionamento do eletrodo no modo "off-channel", na realidade, também é feito no interior do microcanal de separação (Figura 30D), mas o campo originário do potencial de separação é isolado de sua corrente amperométrica através do uso de um desacoplador (por isso o nome "off-channel"). O desacoplador faz o aterramento efetivo do potencial aplicado na separação eletroforética, criando uma região livre de campo elétrico que é justamente onde os analitos são "empurrados" sobre o eletrodo de trabalho ${ }^{110}$. Porem na maioria dos casos trata-se de um processo relativamente complicado.

\subsection{Experimental}

\subsubsection{Reagentes e soluções}

Todos os reagentes usados nessa etapa do trabalho são de pureza analítica. A pureza e a procedência para os reagentes glifosato e AMPA foram apresentadas na seção 3.2.1. O tampão fosfato, utilizado nas medidas eletroquímicas e como eletrólito de trabalho, foi preparado a partir de $\mathrm{Na}_{2} \mathrm{HPO}_{4}$ (J.T. Bake, 99\%) e $\mathrm{NaH}_{2} \mathrm{PO}_{4}$ (Mallinckrodt, 98\% ).

No condicionamento do eletrodo de ouro, para posterior uso em estudos eletroquímicos, foi usado ácido sulfúrico suprapuro. Para estudos eletroquímicos com eletrodo de cobre utilizou-se hidróxido de sódio (Chenco, 97\%). 


\subsubsection{Instrumentação}

\subsubsection{Estudos voltamétricos}

Os ensaios de voltametria cíclica foram realizados em um potenciostato/galvanostato Autolab $^{\circledR}$ modelo PGSTAT 30, controlado pelo o software GPES 4.9. Uma célula eletroquímica convencional, com capacidade de $30 \mathrm{ml}$ foi utilizada. Essa célula possui orifício para encaixe dos eletrodos (trabalho, auxiliar e referencia), alem de orifício para entrada de gás nitrogênio quando necessário (Figura 31).

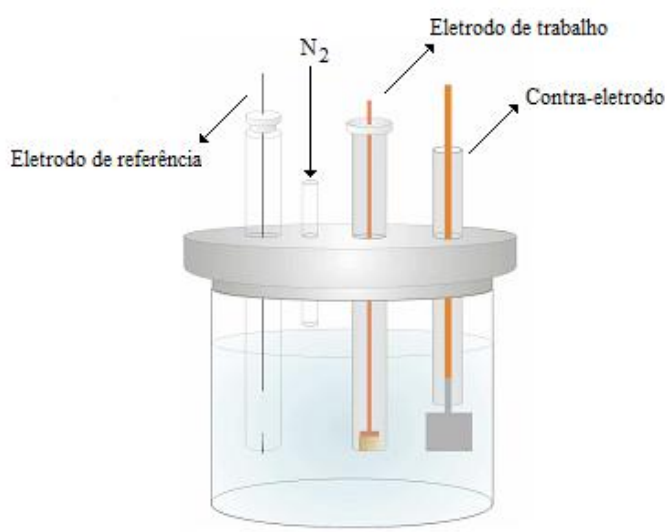

Figura 31. Representação esquemática da célula eletroquímica.

Eletrodos convencionais de cobre e ouro (ambos com $1 \mathrm{~mm}$ de diâmetro) foram utilizados como eletrodo de trabalho, afim de verificar qual metal apresenta melhor sensibilidade para glifosato. Como eletrodo auxiliar (ou contra-eletrodo) foi utilizada uma placa de platina, com $0,5 \mathrm{~cm}^{2}$ de área geométrica, soldada a um fio de platina de $0,5 \mathrm{~mm}$ de diâmetro e embutido em um tubo de vidro. Como eletrodo de referência foi utilizado o eletrodo de $\mathrm{Ag} / \mathrm{AgCl}$ saturado com $\mathrm{KCl}$ 3,0 $\mathrm{mol} \mathrm{L}^{-1}$.

Ambos os eletrodos, ouro e cobre, foram polidos mecanicamente em lixa 2000 e alumina, antes dos ensaios experimentais. Após limpeza mecânica, o eletrodo de ouro foi 
limpo eletroquimicamente através de varias ciclagens em uma solução de $\mathrm{H}_{2} \mathrm{SO}_{4} 1,0$ mol L-1, em intervalo de 0 a $1,75 \mathrm{~V}$ com velocidades de varredura de 1,$0 ; 0,5 ;$ e $0,05 \mathrm{~V} \mathrm{~s}^{-1}$. Para o eletrodo de cobre, a reprodutibilidade foi alcançada promovendo um pré-tratamento de $-0,3 \mathrm{~V}$ por 15 minutos, após o polimento mecânico.

\subsubsection{Confecção do eletrodo planar de cobre}

Os eletrodos planares de cobre foram confeccionados a partir de placas para confecção de circuitos impressos, utilizando o mesmo procedimento para preparação de circuitos ${ }^{111}$.

Inicialmente uma mascara de toner com a configuração desejada foi preparada no software Corel Draw versão 14.0, e impressa em folha acetinada (papel de etiquetas). A imagem impressa na folha foi transferida para a placa usando uma laminadora térmica a $120{ }^{\circ} \mathrm{C}$ por 2 minutos. Posteriormente a placa foi corroída em solução de $\mathrm{Fe}^{3+}$ (preparado comercial), seguido da remoção da máscara de toner com acetonitrila. Resina epóxi foi aplicada sobre os eletrodos, deixando-se descobertos o espaço para contato elétrico e uma pequena região referente a área geométrica ativa do eletrodo, com espessura de $200 \mu \mathrm{m}$ de largura e $3 \mathrm{~mm}$ de altura.

A Figura 32 apresenta o esquema de confecção dos eletrodos, bem como uma imagem ampliada de uma unidade do mesmo depois de pronto. Com cada placa 15 eletrodos foram confeccionados, e com base nos materiais consumidos, um cálculo aproximado do custo de cada eletrodo chegou à ordem de $\mathrm{R} \$ 0,17$. 


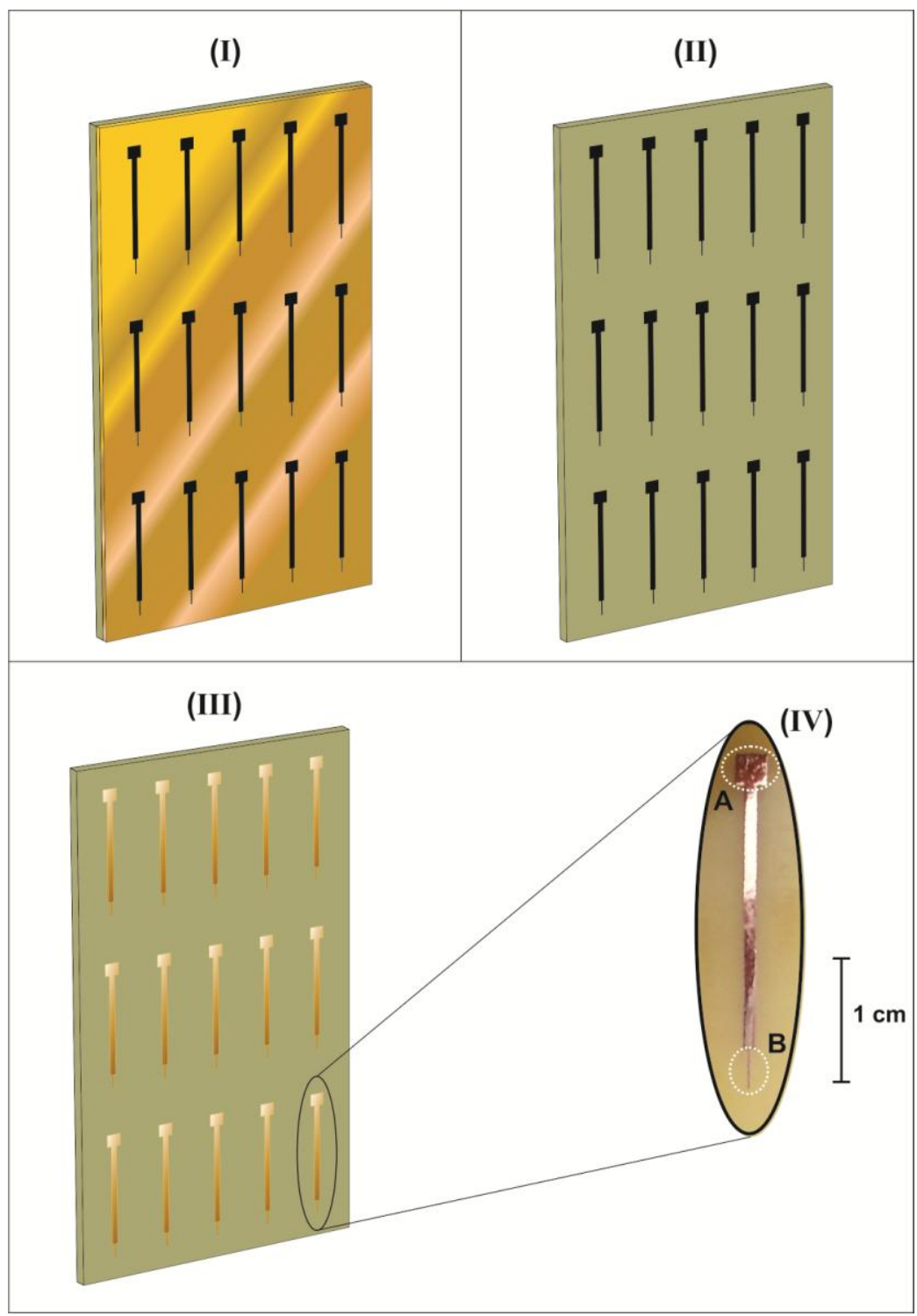

Figura 32. Placa de circuito impresso com a imagem em toner já transferida (I). Placa após corrosão da camada de cobre (II). Placa após remoção do toner por acetonitrila (III). Foto digitalizada do eletrodo depois de pronto (IV), onde $\mathbf{A}$ trata-se da região para contato elétrico e $\mathbf{B}$ da área geométrica ativa do eletrodo.

\subsubsection{Sistema de detecção amperométrica}

O sistema de detecção foi composto por um amplificador de corrente modelo SR570 da Stanford Research System, um mini-potenciostato (lab-made) e uma placa multifuncional PCI-6221 (National Instruments). Neste sistema, a aplicação do potencial fica a cargo do 
potenciostato, enquanto a aquisição do sinal é realizada através dos conversores analógicodigital da placa PCI-6221 que estão conectados à saída do amplificador SR570 responsável pela amplificação e filtragem da corrente que circula pelo eletrodo de trabalho.

O registro do sinal amperométrico foi realizado através do software ED (Electrochemical Detection), desenvolvido por alunos do GMEME do Instituto de Química de São Carlos ${ }^{112}$. Nos experimentos foi utilizado um computador Pentium $42.8 \mathrm{GHz}$ operando LabVIEW 7.1 (National Instruments) em uma plataforma Windows XP. A alimentação do mini-potenciostato tem como escolha o uso de duas baterias de $9 \mathrm{~V}$, função essa inicialmente desenvolvida para realização de medidas "in situ”, porem não utilizada no presente trabalho.

O campo elétrico gerado pelo potencial aplicado na separação eletroforética foi desacoplado do eletrodo de trabalho da detecção amperométrica utilizando a configuração de célula end-channel, no modo off-chip (ver Figura 30B). O comprimento efetivo do microchip de poliéster-toner, utilizado no processo de separação dos analitos em estudo, foi de $45 \mathrm{~mm}$. A instrumentação a cerca do processo de separação eletroforético, tanto quanto o processo de confecção dos microchips de PT, estão apresentados na seção 3.2.3.

\subsection{Resultados e discussão}

\subsubsection{Escolha do eletrodo de trabalho}

Visando o desenvolvimento de uma metodologia simples, sem o uso de eletrodos quimicamente modificados (por exemplo) devido sua alta complexidade de confecção, eletrodos convencionais foram priorizados. Entre os eletrodos metálicos convencionais, eletrodos de cobre e ouro são os mais utilizados na determinação de glifosato ${ }^{58,113}$. 
Os dois eletrodos estudados apresentam limitações de seletividade quando utilizados na determinação de glifosato. Em eletrodo de ouro, a oxidação do herbicida se dá em condições alcalinas, e nesses parâmetros analíticos outras substâncias também sofrem oxidação $^{114,115}$. O eletrodo de cobre é altamente sensível na determinação de substâncias complexantes; porém, em uma solução contendo, por exemplo, aminoácidos e glifosato, o sinal eletroquímico emitido pelo eletrodo seria uma resposta aditiva dos componentes presentes $^{116}$. Somado a esse contexto, o interesse em uma determinação simultânea de compostos justifica o uso da técnica de separação utilizada neste trabalho.

\section{-Eletrodo de Ouro}

Sato e colaboradores ${ }^{113}$ desenvolveram um método para determinação de glifosato utilizando amperometria de pulso em eletrodo de ouro, aliado à cromatografia de troca iônica. Com base nos resultados obtidos por esse autor, a detecção baseada no processo eletrocatalítico promovido pelo metal nobre foi estudada.

A Figura 33A apresenta os voltamogramas cíclicos do eletrodo de ouro em $0,1 \mathrm{~mol} \mathrm{~L}^{-1}$ de $\mathrm{NaOH}\left(\mathrm{pH}\right.$ 13,0), na ausência e na presença de 5,0 $\mathrm{mmol} \mathrm{L}^{-1}$ de glifosato. No voltamograma referente a ausência de glifosato (em preto) foi observado na varredura positiva, a partir do potencial de $+0,30 \mathrm{~V}$, a formação de picos anódicos referentes à formação de óxidos de ouro $(\mathrm{AuOH}$ e $\mathrm{AuO})$ na superfície do eletrodo. Na varredura negativa, verifica-se um pico catódico em aproximadamente $+0,17 \mathrm{~V}$ relacionado a redução dos óxidos na superfície do eletrodo. Um pico catódico em $-0,1 \mathrm{~V}$ é atribuído a redução do oxigênio dissolvido. Na presença de glifosato (em vermelho) um incremento na corrente anódica é observado próximo de $+0,2 \mathrm{~V}$, devido à oxidação do herbicida na superfície do eletrodo de ouro. Uma dependência linear entre a corrente anódica e a concentração do herbicida é 
apresentada na Figura 33B. Um pré-tratamento de $-0,3 \mathrm{~V}$ por cinco segundos foi realizado no eletrodo antes de cada ciclagem.
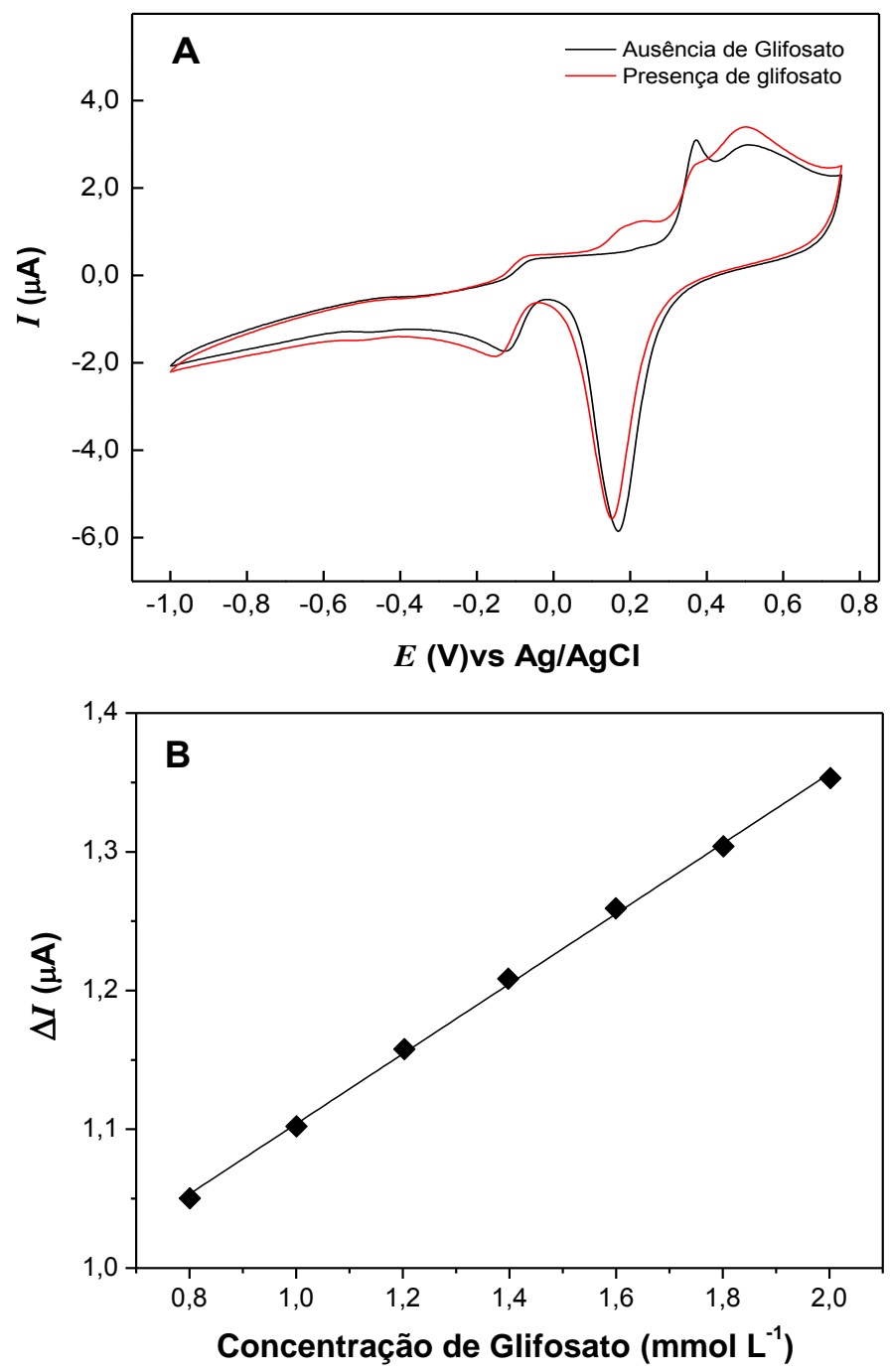

Figura 33. Voltamogramas na presença $\left(5,0 \mathrm{mmol} \mathrm{L}^{-1}\right)$ e ausência de glifosato, em solução de $\mathrm{NaOH}$ $0,1 \mathrm{~mol} \mathrm{~L}^{-1}$; usando eletrodo de ouro (1 mm de diâmetro). Velocidade de varredura $100 \mathrm{mV} \mathrm{s}^{-1}$ (A). Resposta eletroquímica para diferentes concentrações de glifosato em eletrodo de ouro (B).

Segundo Sato, o glifosato contém grupos amino primário e secundário que podem ser oxidados em eletrodos de ouro sob condições alcalinas. Os autores quantificaram o herbicida com a mesma metodologia de análise de aminoácidos (já que é derivado e o comportamento eletroquímico é semelhante). Johnson e LaCours ${ }^{117}$ propuseram um mecanismo de reação 
eletroquímica para aminas na superfície de eletrodos de ouro. Esses autores acreditam que com o eletrodo de ouro livre de óxidos, as aminas são adsorvidas em sua superfície a partir do par de elétrons desemparelhados do átomo de nitrogênio. Em condições alcalinas, e em resposta a um potencial positivo aplicado, as espécies adsorvidas são dessorvidas simultaneamente com o processo de formação dos óxidos de ouro, gerando assim bons sinais analíticos para as espécies de interesse. Dessa forma, para promover o fenômeno de adsorção/dessorção e se conseguir bons resultados, amperometria pulsada deve ser usada (do inglês Pulsed Amperometric Detection - PAD).

\section{-Eletrodo de Cobre}

O glifosato é conhecido por sua habilidade complexante, principalmente na formação de complexos com metais de transição. A molécula deste herbicida possui três grupos funcionais (amino, carboxilato e fosfonato) que podem coordenar com o $\mathrm{Cu}$ (II). Assim, a detecção eletroquímica utilizando eletrodo de cobre pode ser utilizada para a determinação deste herbicida ${ }^{118}$. Basicamente promove-se a aplicação de um potencial para formação de uma camada de óxidos de cobre, que é dissolvida na presença de um agente complexante. Dessa forma o equilíbrio da reação de formação de óxidos é deslocado, aumentando então a corrente anódica do eletrodo, gerando um sinal analítico.

A Figura 34A apresenta os voltamogramas cíclicos do eletrodo de cobre em $0,1 \mathrm{~mol} \mathrm{~L}^{-1}$ de tampão fosfato $(\mathrm{pH} 7,5)$, na ausência e na presença de $1,0 \mathrm{mmol} \mathrm{L}^{-1}$ de glifosato. No voltamograma referente a ausência de glifosato (em preto), foi observada na varredura positiva a formação do filme de óxidos de cobre próximo ao potencial de $-0,015 \mathrm{~V}$, com posterior estabilização da corrente até $0,7 \mathrm{~V}$. Na varredura negativa o pico em $-0,21 \mathrm{~V}$ foi atribuído a redução do óxido na superfície. Na presença de glifosato (em vermelho), verifica-se na varredura positiva um aumento na corrente anódica na faixa de $-0,15$ a $0,7 \mathrm{~V}$, 
relacionado a dissolução da camada de óxidos causada pelo glifosato (e formação do complexo glifosato- $\left.\mathrm{Cu}^{2+}\right)$. Na varredura negativa, observa-se uma diminuição significativa da corrente de redução dos óxidos. Esta variação no comportamento catódico pode estar associada a solubilização parcial do óxido de cobre presente na superfície do eletrodo. A Figura 34B apresenta a dependência linear entre a corrente anódica para glifosato, em função de sua concentração.
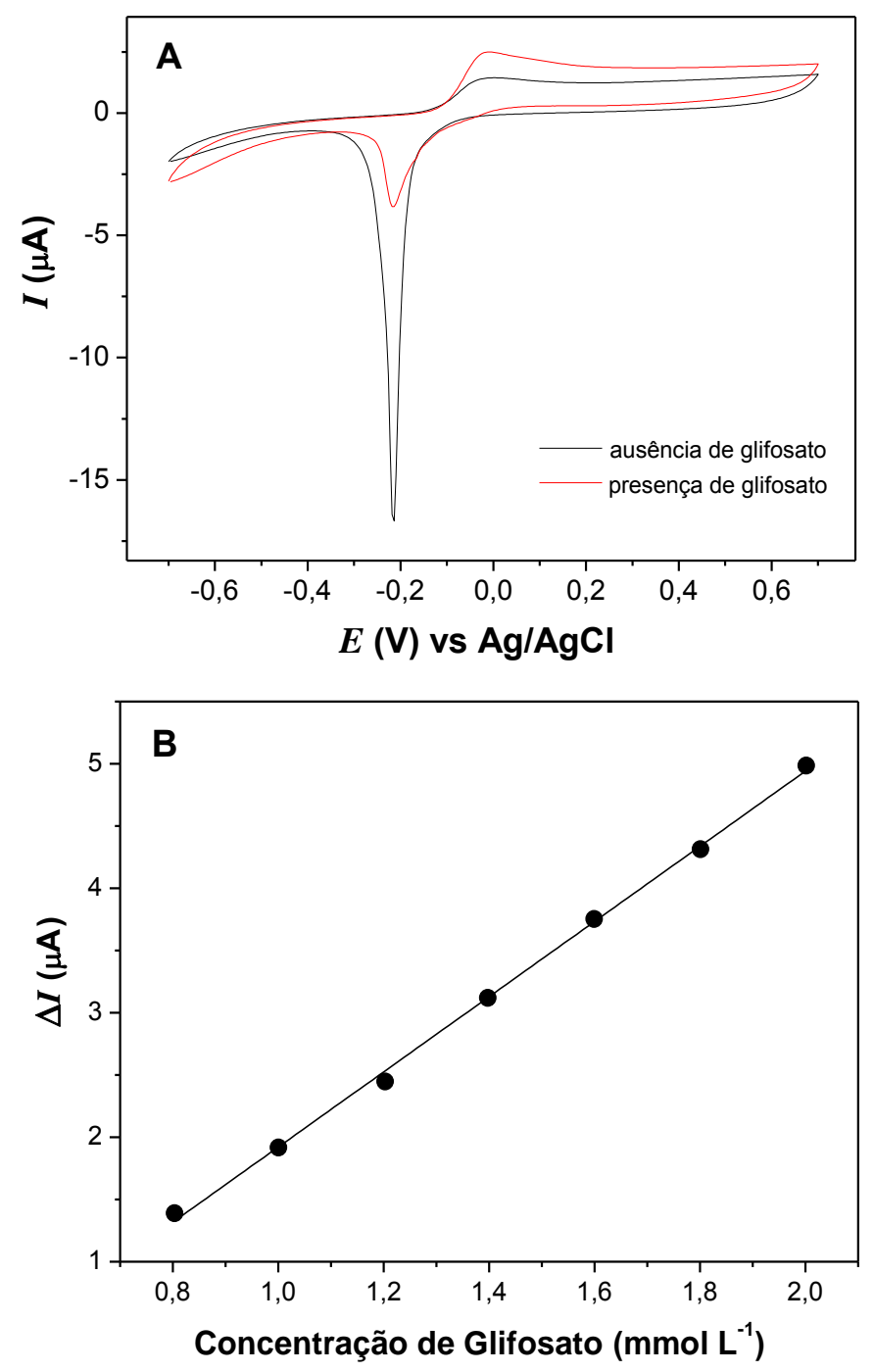

Figura 34. Voltamogramas cíclicos do eletrodo de cobre em $0,1 \mathrm{~mol} \mathrm{~L}^{-1}$ de tampão fosfato na ausência e na presença de $1,0 \mathrm{mmol} \mathrm{\textrm {L } ^ { - 1 }}$ de glifosato. Velocidade de varredura $100 \mathrm{mV} \mathrm{s}^{-1}$ (A). Resposta eletroquímica para diferentes concentrações de glifosato em eletrodo de cobre (B). Eletrodo de cobre com $1 \mathrm{~mm}$ de diâmetro. 
Devido à polarização positiva em eletrodo de cobre, o surgimento de um filme de óxido em sua superfície é verificado. Inicialmente uma camada compacta de $\mathrm{Cu}_{2} \mathrm{O}$ é formada; em seguida há o surgimento de uma camada amorfa composta por $\mathrm{Cu}_{2} \mathrm{O}, \mathrm{CuO}$ e pequenas quantidades de sais de cobre (dependentes da composição da solução) ${ }^{119}$. Quando na presença de agentes complexantes, a resposta eletroquímica do eletrodo de cobre ocorre da interação de tais substancias com íons $\mathrm{Cu}(\mathrm{II})$ provenientes da dissolução natural da camada de óxidos (reação 2). Ou ainda, da interação direta entre os complexantes e a camada de óxidos de cobre na superfície do eletrodo (reação 1); onde os complexantes dissolvem a camada do óxido de cobre, deslocando o equilíbrio da reação de formação do óxido no sentido dos produtos, resultando em um aumento da corrente anódica (maior formação de óxido). O aumento da corrente anódica do eletrodo de cobre é proporcional à concentração do agente complexante contido na solução, e depende também do poder complexante da substância ${ }^{120}$.

$$
\begin{aligned}
& \mathrm{Cu}+\mathrm{H}_{2} \mathrm{O} \rightleftharpoons \mathrm{CuO}+2 \mathrm{H}^{+}+2 e^{-} \\
& \mathrm{CuO}+2 \mathrm{H}^{+} \rightleftharpoons \mathrm{Cu}(\mathrm{II})+\mathrm{H}_{2} \mathrm{O}
\end{aligned}
$$

\section{- Comparação do desempenho analítico dos eletrodos de ouro e cobre}

O desempenho analítico dos eletrodos de cobre e ouro foram comparados entre si, com base em suas respectivas sensibilidades para glifosato. A Figura 35 apresenta as relações lineares do sinal voltamétrico em função da concentração de glifosato para os eletrodos de ouro e cobre. 


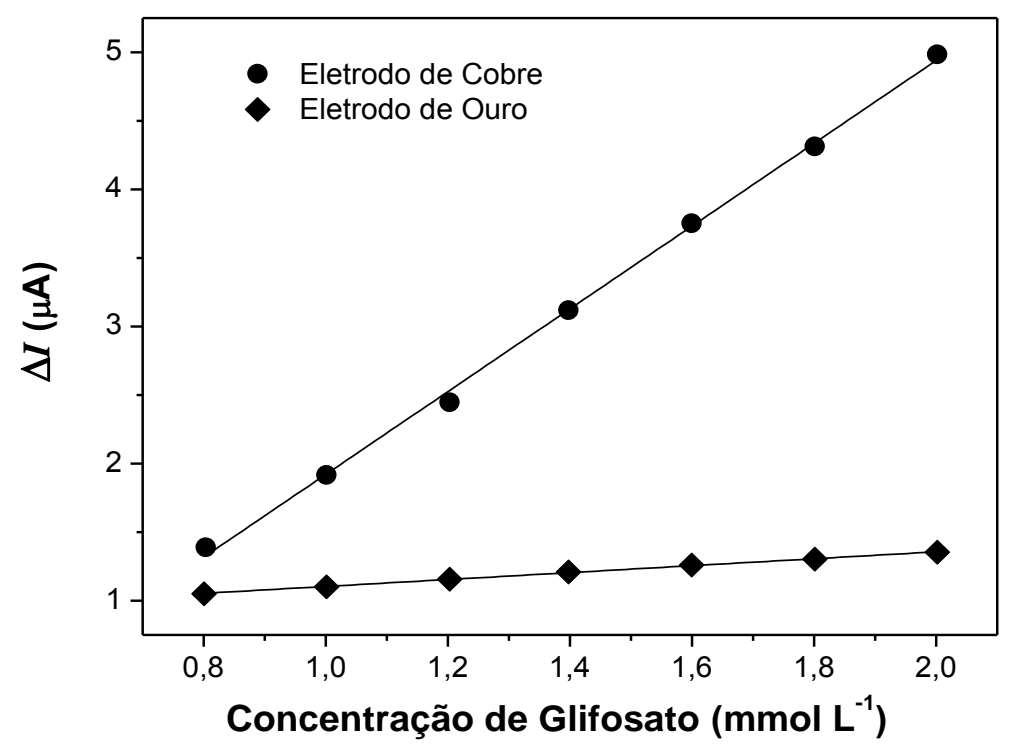

Figura 35. Comparação da resposta eletroquímica do glifosato em eletrodo de cobre e ouro.

A Tabela 7 mostra os principais parâmetros a cerca da regressão linear para o eletrodo de cobre, tanto quanto para eletrodo de ouro. Os resultados apresentados mostram uma maior sensibilidade para o eletrodo de cobre em relação ao eletrodo de ouro. Com base nesses resultados, o eletrodo de cobre foi tomado como melhor escolha para determinação amperométrica de glifosato.

Tabela 7. Comparação dos parâmetros da regressão linear, obtidos na variação de concentração de glifosato em eletrodo de ouro e cobre. Numero de pontos $=7$.

\begin{tabular}{ccccc}
\hline Eletrodo & $\begin{array}{c}\text { Sensibilidade } \\
\text { Experimental } \\
(\boldsymbol{y}=\mathbf{B} \boldsymbol{x})\end{array}$ & $\begin{array}{c}\text { Coeficiente de } \\
\text { correlação }(\mathbf{R})\end{array}$ & $\mathbf{p H}$ & $\begin{array}{c}\text { Eletrólito } \\
\left(\mathbf{0 , 1} \mathbf{~ m o l ~ L}^{-1}\right)\end{array}$ \\
\hline Ouro & $y=2,53 x$ & 0,9995 & 13,0 & $\begin{array}{c}\text { Solução de NaOH } \\
\text { (oxidação) }\end{array}$ \\
Cobre & $y=30,2 x$ & 0,9993 & 7,5 & $\begin{array}{c}\text { Tampão Fosfato } \\
\text { (complexação) }\end{array}$ \\
\hline
\end{tabular}




\subsubsection{Acoplamento do sistema eletroforético à detecção eletroquímica}

Para o acoplamento entre eletroforese em microchips de PT e detecção eletroquímica, um suporte em acrílico estrategicamente confeccionado para esse fim foi utilizado (Figura 36). O suporte apresenta um posicionador $x-y$ que promove o alinhamento entre o final do microcanal de separação do microdispositivo, e o eletrodo planar de cobre construído a partir de placas de circuito impresso (ver seção 4.2.2.2.).

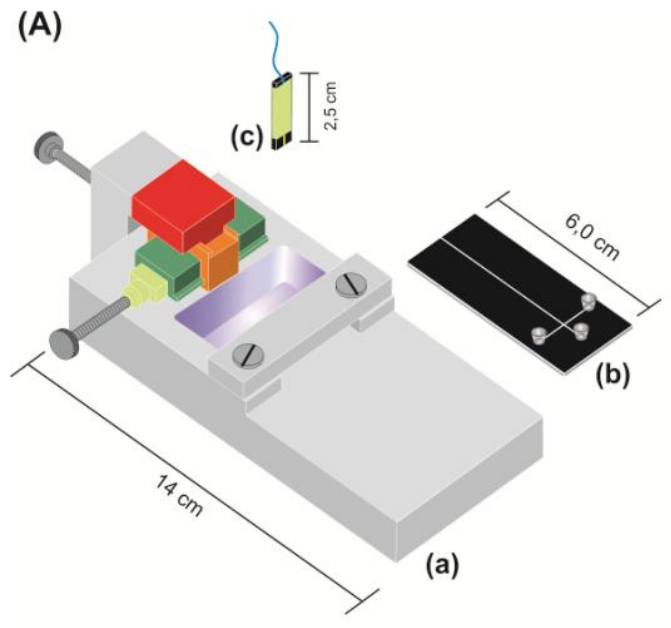

(B)

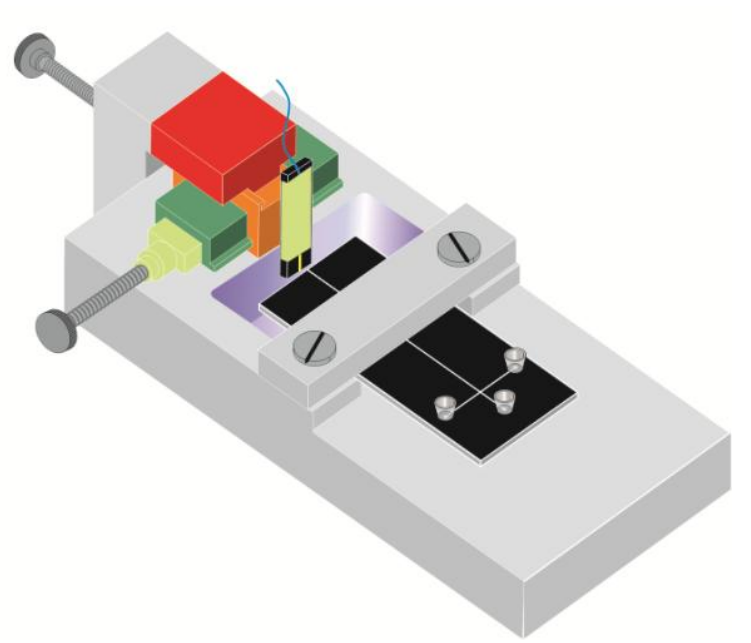

Figura 36. Desenho esquemático do sistema usado para o acoplamento entre eletroforese em microdispositivos e detecção eletroquímica. (A) Partes do sistema: (a) suporte em acrílico com posicionador $x-y$, (b) microdispositivo fabricado em PT e (c) eletrodo de cobre fabricado a partir de placas de circuito impresso. (B) Acoplamento do microdispositivo e do eletrodo de trabalho no suporte.

O suporte em acrílico apresentado, tem capacidade aproximada de $6 \mathrm{~mL}$ de solução. Os demais eletrodos da célula eletroquímica (auxiliar e de referência, bem como o eletrodo de aterramento da fonte usado para eletroforese), foram posicionados em lados opostos no reservatório de detecção. O eletrodo de trabalho confeccionado a partir de placas de circuito impresso foi avaliado de acordo com seu perfil voltamétrico (Figura 37), estando de acordo com resultados encontrados na literatura ${ }^{121,122}$. 


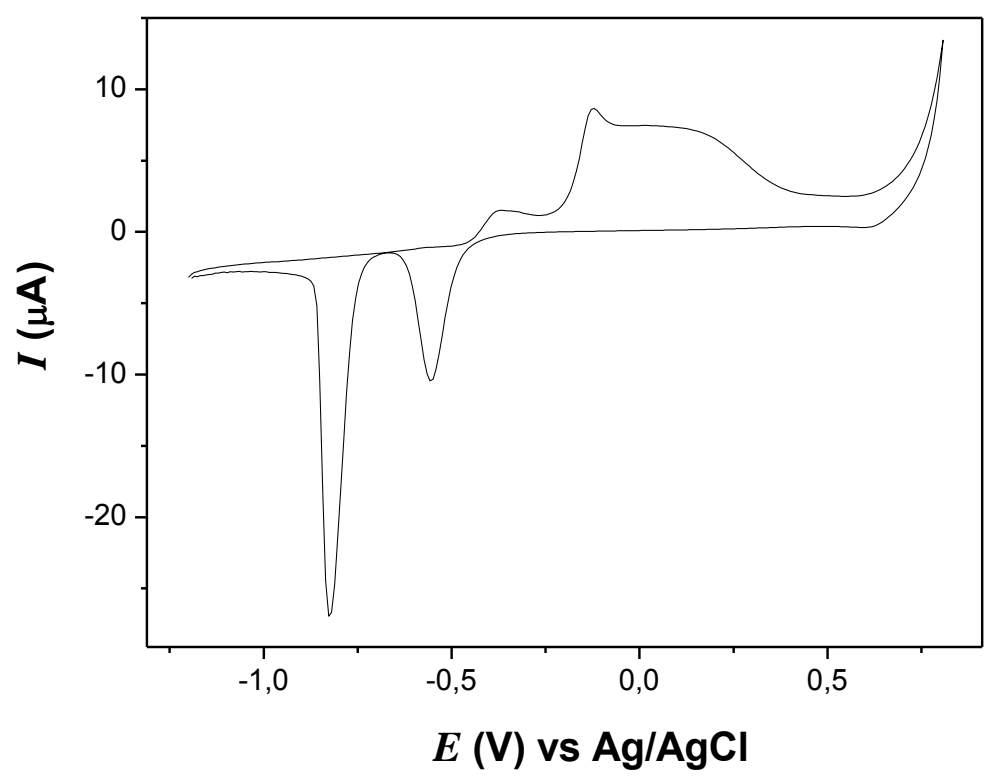

Figura 37. Voltamograma cíclico do eletrodo de cobre confeccionado a partir de placas de circuito impresso em $0,1 \mathrm{~mol} \mathrm{~L}^{-1}$ de $\mathrm{NaOH}$ (pH 13,0). Velocidade de varredura $100 \mathrm{mV} \mathrm{s}^{-1}$.

Usando as configurações citadas anteriormente, testes foram realizados buscando um sinal analítico para glifosato e AMPA. A Figura 38 apresenta o eletroferograma obtido para uma mistura desses analitos utilizado polaridade negativa no sistema de separação, onde uma separação eficiente é observada em tampão fosfato.

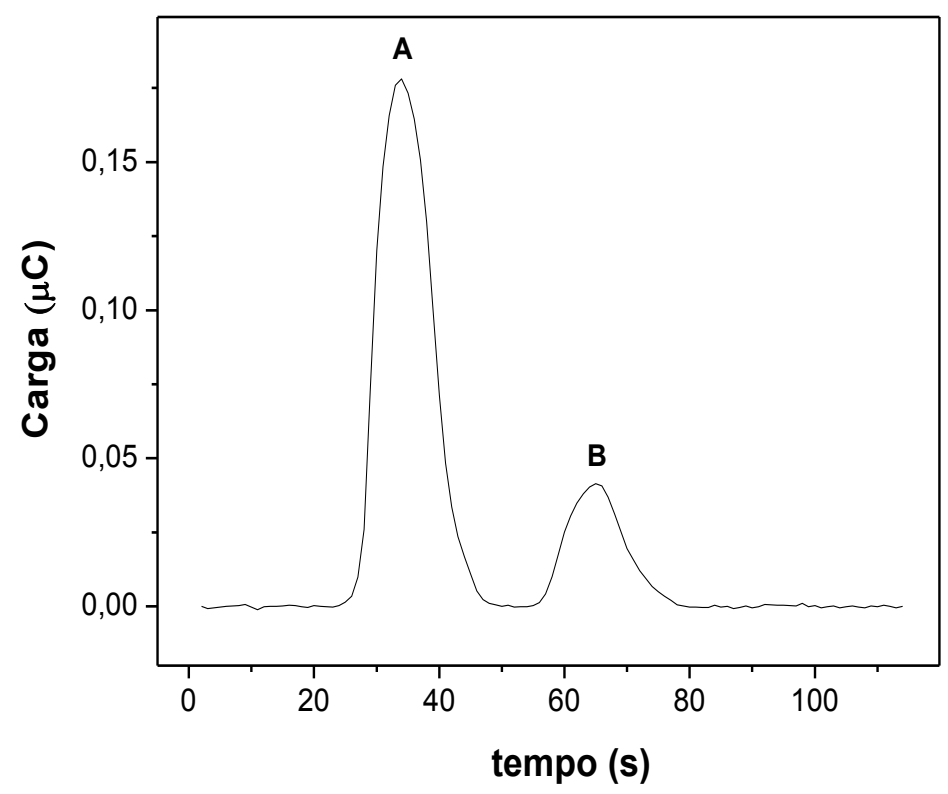

Figura 38. Eletroferograma de uma mistura contendo $100 \mu \mathrm{mol} \mathrm{L} \mathrm{L}^{-1}$ de glifosato (A) e $500 \mu \mathrm{mol} \mathrm{L^{-1 }}$ de AMPA (B). Condições: Tampão fosfato $10 \mathrm{mmol} \mathrm{L}^{-1}, \mathrm{pH} 7,5$. Injeção:-1,0 kV/10 s; potencial de separação: $-1,0 \mathrm{kV}$. Potencial do eletrodo de trabalho: $0,1 \mathrm{~V}$. 


\subsubsection{Otimização do potencial de detecção eletroquímico}

Com o posicionamento do eletrodo de trabalho a algumas dezenas de micrometros do canal de separação, o campo elétrico gerado pelo potencial de separação fica efetivamente isolado do eletrodo de trabalho. Uma linha de base estável no eletroferograma comprova isso. Entretanto, o campo elétrico gerado pelo sistema eletroforético pode provocar um deslocamento significativo no potencial do eletrodo de trabalho. Dessa forma para se determinar o potencial ótimo para o eletrodo de trabalho, o estudo deve ser conduzido sobre condições eletroforéticas de separação.

Foram injetadas misturas de padrões de glifosato e AMPA, em diferentes potenciais do eletrodo de trabalho. A janela de potencial avaliada variou de 0,05 a $0,25 \mathrm{~V}$, como pode ser obervado na Figura 39. O gráfico apresenta um máximo de resposta eletroquímica (em função da área do pico) em $0,15 \mathrm{~V}$; desta forma, este potencial foi escolhido como ideal para os experimentos seguintes.

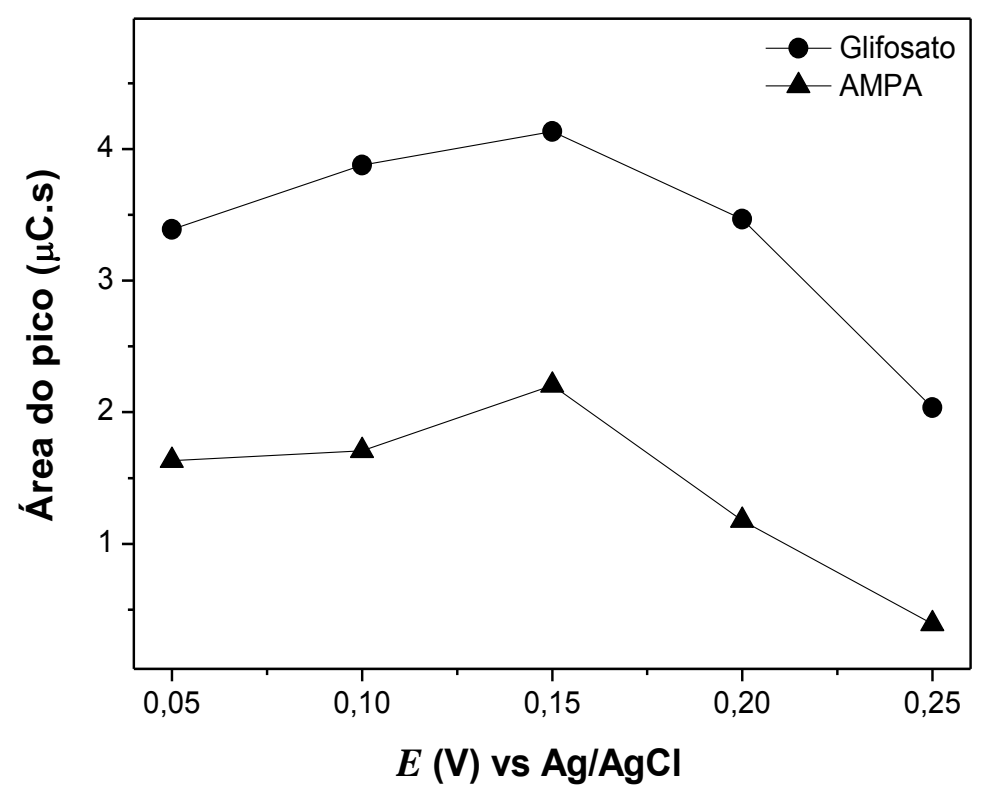

Figura 39. Variação da área do pico para glifosato e AMPA, em função do potencial aplicado no eletrodo de trabalho. Outras condições ver Figura 38. 


\subsubsection{Influência do pH e concentração do tampão fosfato}

A variação do $\mathrm{pH}$ do tampão fosfato apresentou pouca influência nos parâmetros relacionados a separação eletroforética. Com a variação do $\mathrm{pH}$, a mudança mais significativa foi encontrada no sinal analítico. De acordo com a literatura ${ }^{123,124}$, agentes complexantes geram um máximo de corrente anódica em eletrodo de cobre quando utilizado tampão fosfato com pH entre 6,2 e 7,2 .

A dependência da área do pico dos analitos com a variação do $\mathrm{pH}$ é apresentada na Figura 40, os pHs estudados vão de 5,91 a 7,81. De acordo com o gráfico, o maior valor de área de pico é encontrado para ambos analitos em pH 6,38. Estes resultados estão de acordo com os encontrados por Coutinho ${ }^{125}$, que verifica uma maior sensibilidade para glifosato em eletrodo de cobre utilizando tampão fosfato próximo a pH 6,5.

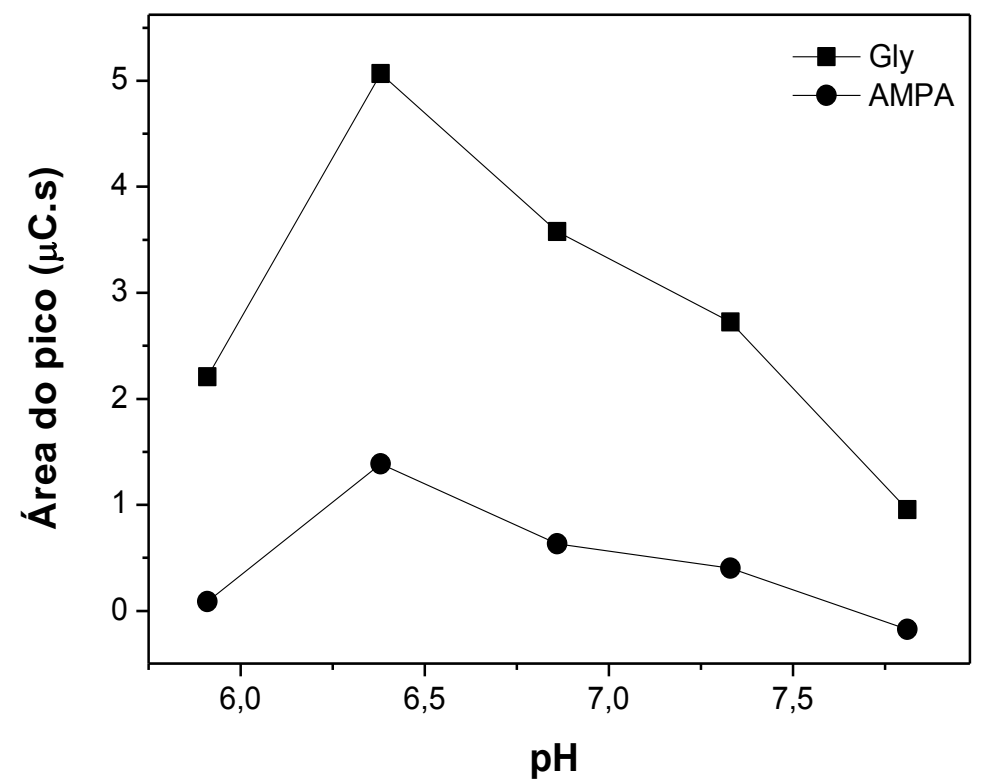

Figura 40. Área do pico para glifosato e AMPA em função do pH. Condições: Tampão fosfato 10 mmol L ${ }^{-1}$. Injeção:-1,0 kV $/ 10 \mathrm{~s}$; potencial de separação: $-1,0 \mathrm{kV}$. Potencial do eletrodo de trabalho: 0,15 V. Concentração de glifosato e AMPA a 100 e $500 \mu \mathrm{mol} \mathrm{L}^{-1}$ respectivamente. 
Como comentado anteriormente, a priori $\mathrm{pHs}$ alcalinos seriam utilizados com intuito de promover a ionização dos analitos em estudo, e consequentemente torna-los suscetíveis à separação eletroforética. Entretanto, considerando apenas a resposta ao detector eletroquímico como referência, um valor de pH próximo da neutralidade foi encontrado como ótimo.
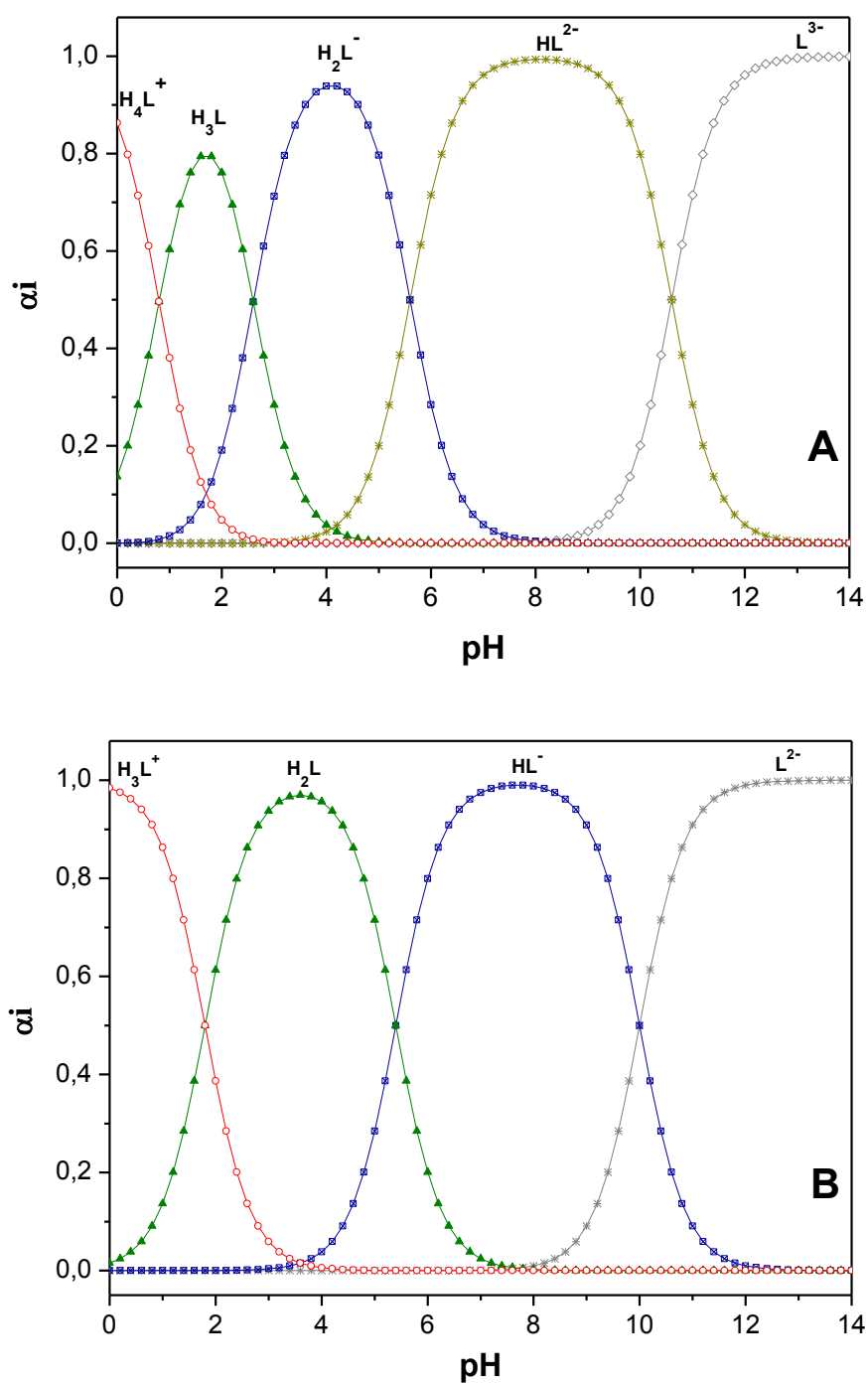

Figura 41. Diagrama de distribuição de espécies em função do pH para glifosato (A) e AMPA (B).

Analisando os diagramas de distribuição de espécies para glifosato e AMPA da Figura 41A e 41B (obtidos através do programa CurTiPot ${ }^{126}$ ), verifica-se que $85,6 \%$ do glifosato se 
encontra na forma ${ }^{\dagger} \mathrm{HL}^{2-}$ e 14,4\% na forma $\mathrm{H}_{2} \mathrm{~L}^{-}$. Para AMPA 90,5\% se encontra na forma $\mathrm{HL}^{-1}$ e $9,5 \%$ na forma $\mathrm{H}_{2} \mathrm{~L}$. Constata-se portanto, que mesmo trabalhando com um valor de pH próximo da neutralidade ( $\mathrm{pH} 6,4)$, a porção majoritária dos analitos se encontram em seu estado iônico; assim, a injeção das amostras por aplicação de um campo elétrico pode ser promovida, seguido de uma eficiente separação eletroforética.

Utilizando-se do valor de $\mathrm{pH}$ no qual uma maior sensibilidade foi verificada, a resposta para glifosato e AMPA em eletrodo de cobre foi examinada em diferentes concentrações do tampão fosfato. O intervalo de concentração estudado foi de 2,5 a 10 mmol L ${ }^{-1}$. Nesse estudo parâmetros eletroforéticos como tempo de migração e resolução entre os picos não tiveram uma variação significativa.

Observa-se na Figura 42 um maior valor de área de pico para os analitos em $5 \mathrm{mmol} \mathrm{L}^{-1}$ de tampão fosfato, dessa forma essa concentração foi escolhida para o desenvolvimento do trabalho.

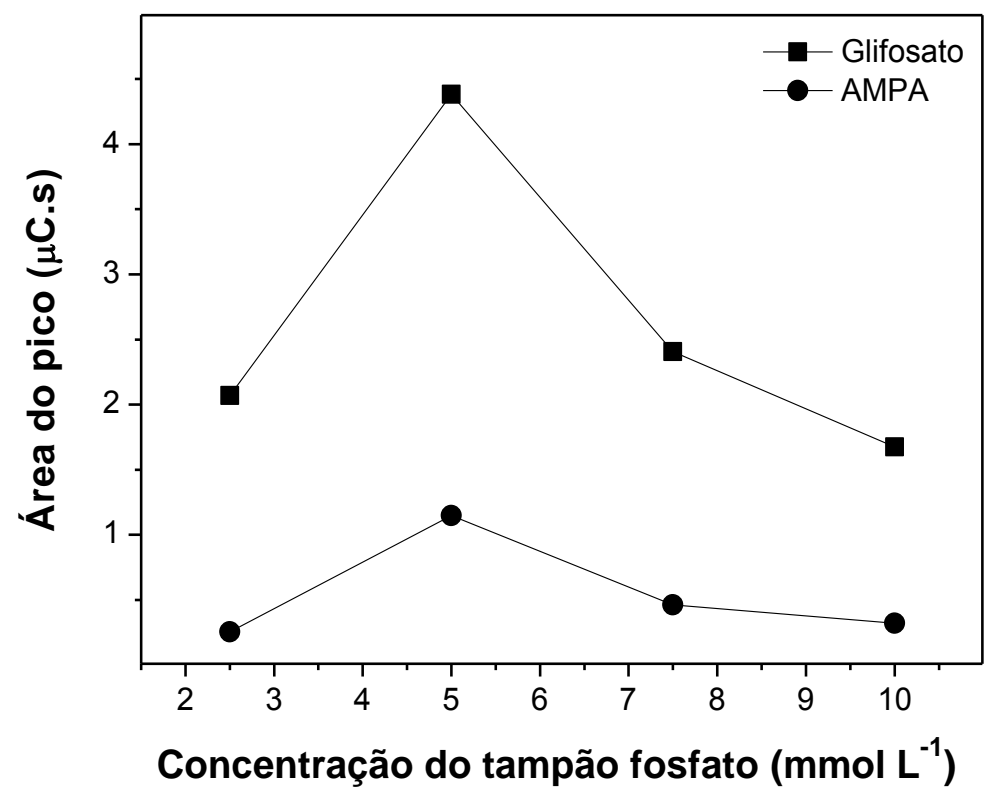

Figura 42. Dependência das áreas de pico para glifosato e AMPA com a variação da concentração do tampão fosfato.

\footnotetext{
${ }^{\dagger}$ Modelo genérico, onde $\mathrm{H}_{3} \mathrm{~L}$ e $\mathrm{H}_{2} \mathrm{~L}$ representam as moléculas neutras de glifosato e AMPA respectivamente.
} 


\subsubsection{Tempo de injeção e curva de Ohm}

O tempo ideal de injeção foi determinado a partir da introdução eletrocinética de uma mistura de $100 \mu \mathrm{mol} \mathrm{L}{ }^{-1}$ de glifosato e $500 \mu \mathrm{mol} \mathrm{L} \mathrm{L}^{-1}$ de AMPA, variando-se os tempos de injeção de 4 a 18 s sobre aplicação de $1,0 \mathrm{kV}$. As Figuras 43 e 44 apresentam, respectivamente, a intensidade do sinal e a largura do pico para glifosato em função do tempo de injeção. Observa-se nas Figuras uma tendência à estabilização na intensidade e na largura dos picos para glifosato a partir de 14 s. Constatou-se ainda uma sobreposição dos picos para glifosato e AMPA para tempos superiores a esse. Dessa forma, o tempo de injeção de 14 s foi escolhido por preencher suficientemente a intersecção entre os canais de injeção e separação, e não prejudicar a resolução entre os picos.

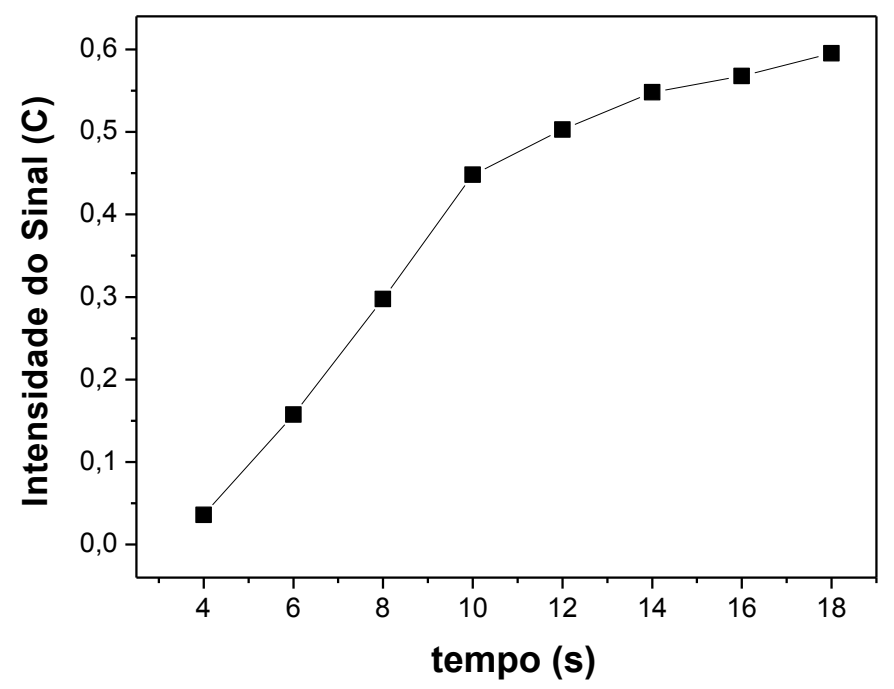

Figura 43. Gráfico da intensidade do sinal para glifosato em função do tempo de injeção. 


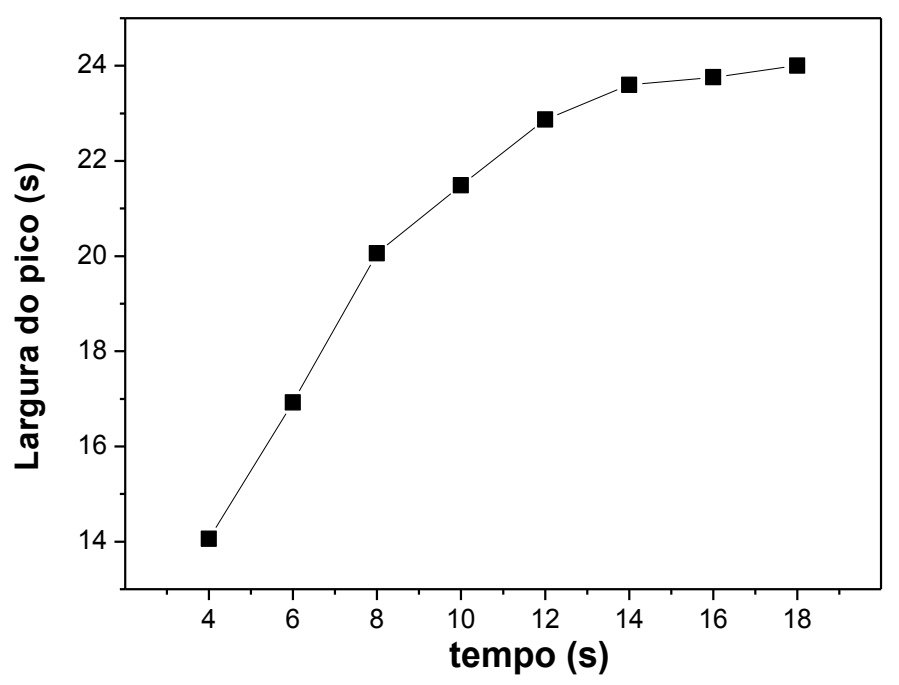

Figura 44. Gráfico da largura do pico para glifosato em função do tempo de injeção.

A capacidade de dissipar calor do microchip de PT foi investigada utilizando os parâmetros analíticos otimizados. Para isso, o microcanal de separação foi preenchido com tampão fosfato $\left(5 \mathrm{mmol} \mathrm{L}^{-1}, \mathrm{pH}\right.$ 6,38) e uma diferença de potencial foi aplicada ao microcanal. Uma relação linear entre corrente resultante e potencial aplicado é encontrada até 1,7 kV (Figura 45); a partir deste valor há um desvio resultante do aquecimento provocado pelo efeito Joule.

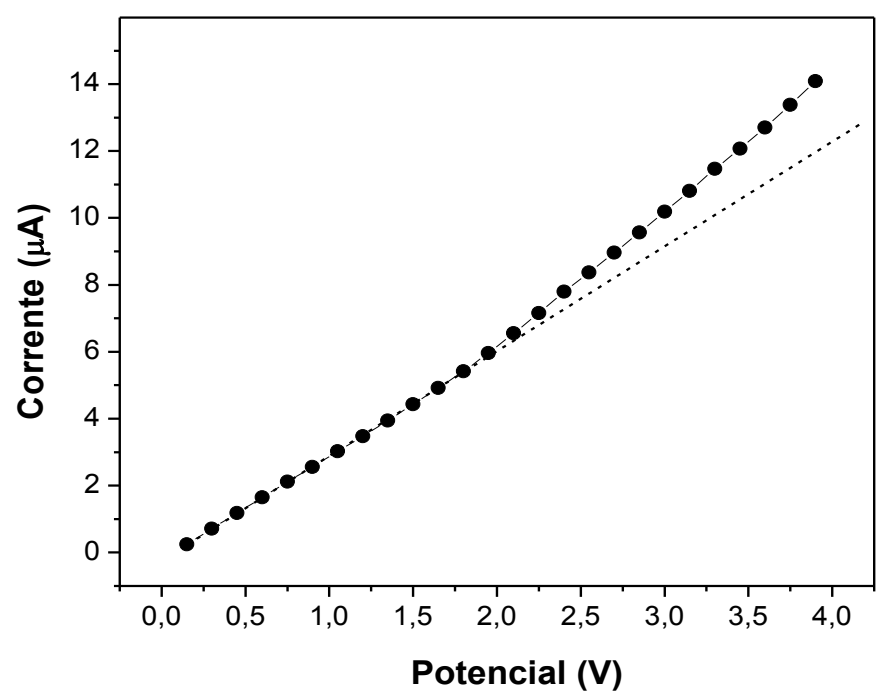

Figura 45. Curva obtida para a corrente eletroforética em função do potencial aplicado. 


\subsubsection{Repetibilidade e curva analítica}

Para verificação da repetibilidade do método desenvolvido, seis injeções consecutivas foram realizadas para uma mistura de $100 \mu \mathrm{mol} \mathrm{L}^{-1}$ de glifosato e $500 \mu \mathrm{mol} \mathrm{L}^{-1}$ de AMPA (Figura 46). Os valores de RSD obtidos para as áreas de pico do glifosato e do AMPA foram de 11,7 e $18,1 \%$ respectivamente. Descartando os valores de área de pico obtidos na primeira injeção, com base na discussão realizada na seção 3.3.7, os valores de RSD caem para 5,8\% para glifosato e $8,6 \%$ para AMPA.

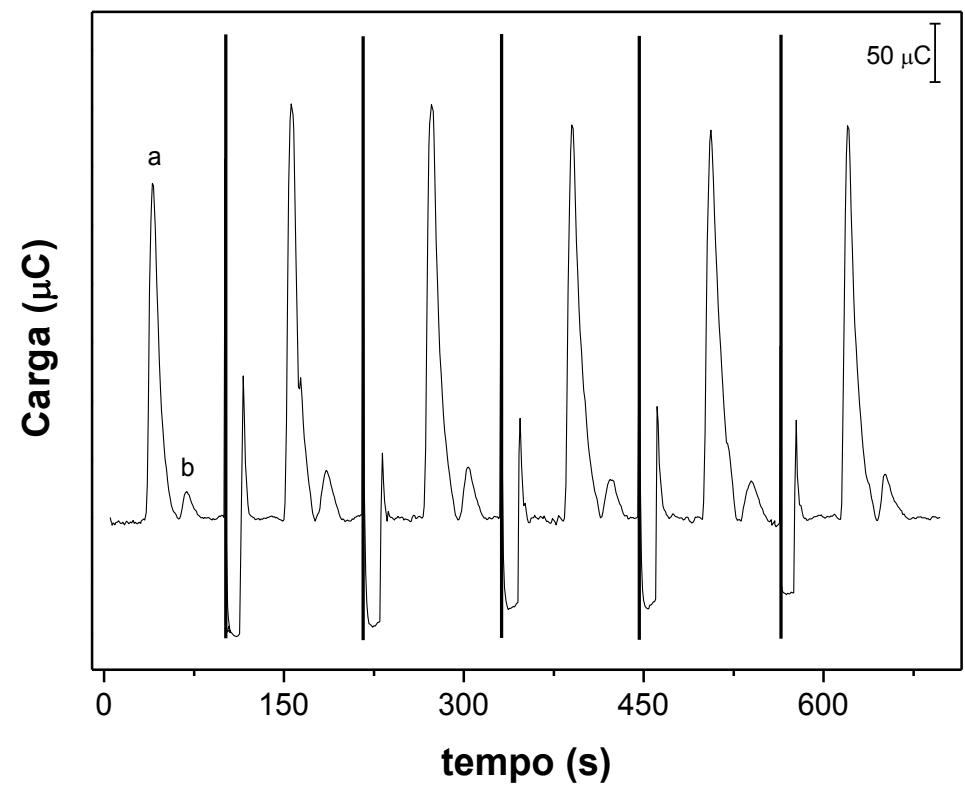

Figura 46. Sequência de seis eletroferogramas obtidos para a separação de glifosato (a) com concentração de $100 \mu \mathrm{mol} \mathrm{L}^{-1}$ e AMPA (b) a $500 \mu \mathrm{mol} \mathrm{L}^{-1}$. Condições: Tampão fosfato $5 \mathrm{mM}$, pH 6,4. Injeção:-1,0 kV/14 s; potencial de separação: $-1,7 \mathrm{kV}$. Potencial do eletrodo de trabalho: $0,15 \mathrm{~V}$.

Após otimizar as melhores condições de trabalho para o método desenvolvido, e constatar uma boa repetibilidade entre as injeções; uma verificação a cerca da correlação entre as concentrações analíticas e as áreas de pico para ambos os analitos foi realizada. As curvas analíticas para glifosato e AMPA estão apresentadas nas Figuras 47A e 47B respectivamente, onde cada ponto nas curvas é um valor médio de três medidas. Os coeficientes de correlação 
linear encontrados foram 0,9999 7 para glifosato, e 0,9996 9 para AMPA. Os valores de LD calculados a partir de parâmetros da curva analítica ${ }^{86}$ foram de $1,88 \mu \mathrm{mol} \mathrm{L} \mathrm{L}^{-1}\left(317,91 \mu \mathrm{g} \mathrm{L}^{-1}\right)$ para glifosato, e 16,45 $\mu \mathrm{mol} \mathrm{L}{ }^{-1}$ para AMPA. Para garantir a reprodutibilidade do método foi realizado um pré-tratamento no eletrodo de cobre aplicando-se $-0,3 \mathrm{~V}$ por 60 s e $0,3 \mathrm{~V}$ por mais $60 \mathrm{~s}$ antes de cada injeção.
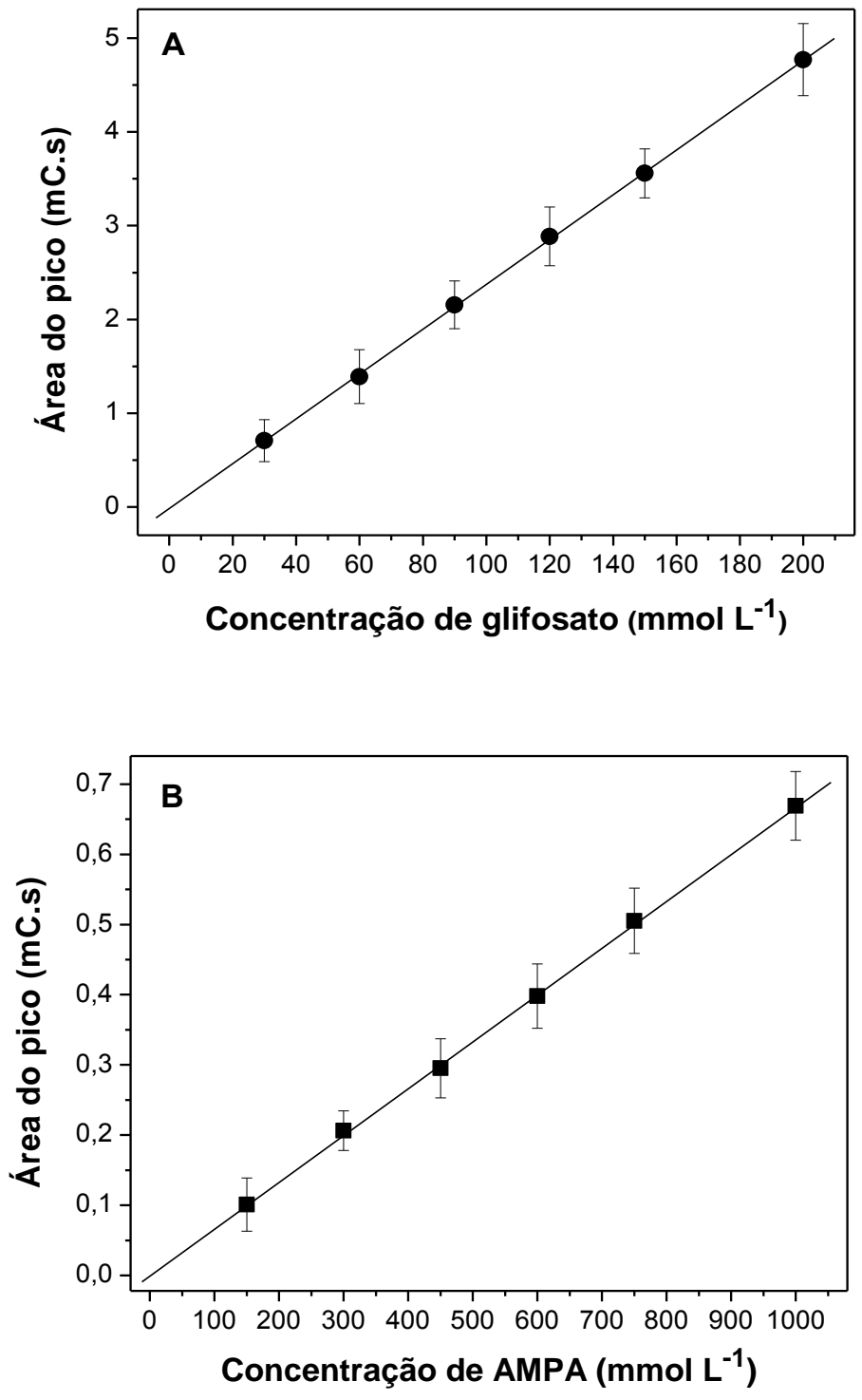

Figura 47. Curvas analíticas para glifosato (A) e AMPA (B), obtidas utilizando detecção amperométrica em eletrodo de cobre confeccionado a partir de placas de circuito impresso, aliada a separação eletroforética em microchips de PT. Outras condições ver Figura 46. 
O método desenvolvido forneceu um limite de detecção adequado para a análise de glifosato em águas de consumo humano que atenda as exigências da ANVISA ${ }^{87}$. Segundo esse órgão regulamentador, o valor máximo permitido de glifosato em água potável é de $500 \mu \mathrm{g} \mathrm{L}^{-1}$, portanto, com um LD de $317,9 \mu \mathrm{g} \mathrm{\textrm {L } ^ { - 1 }}$ o método desenvolvido atende a tais exigências.

\subsubsection{Amostra real}

A aplicabilidade do método foi avaliada através da análise de glifosato e AMPA em amostras de água potável. Para os cálculos de recuperação, concentrações conhecidas do padrão foram adicionadas à amostra e os resultados obtidos na análise foram comparados com as concentrações adicionadas. Para os testes realizados, não foram encontrados traços do pesticida e seu metabólito nas amostras de água potável.

A Figura 48 apresenta o eletroferograma da amostra fortificada com $100 \mu \mathrm{mol} \mathrm{L} \mathrm{L}^{-1} \mathrm{de}$ glifosato e $500 \mu \mathrm{mol} \mathrm{L}{ }^{-1}$ de AMPA. A ausência de outros picos na análise de amostras reais revela a ausência de possíveis interferentes (substâncias complexantes com cobre). Com recuperações de $90,6 \%$ e $86,5 \%$ para glifosato e AMPA respectivamente, os resultados obtidos podem ser considerados satisfatórios, pois se enquadram na faixa de recuperação recomendada para a análise de pesticidas ${ }^{95}$. 


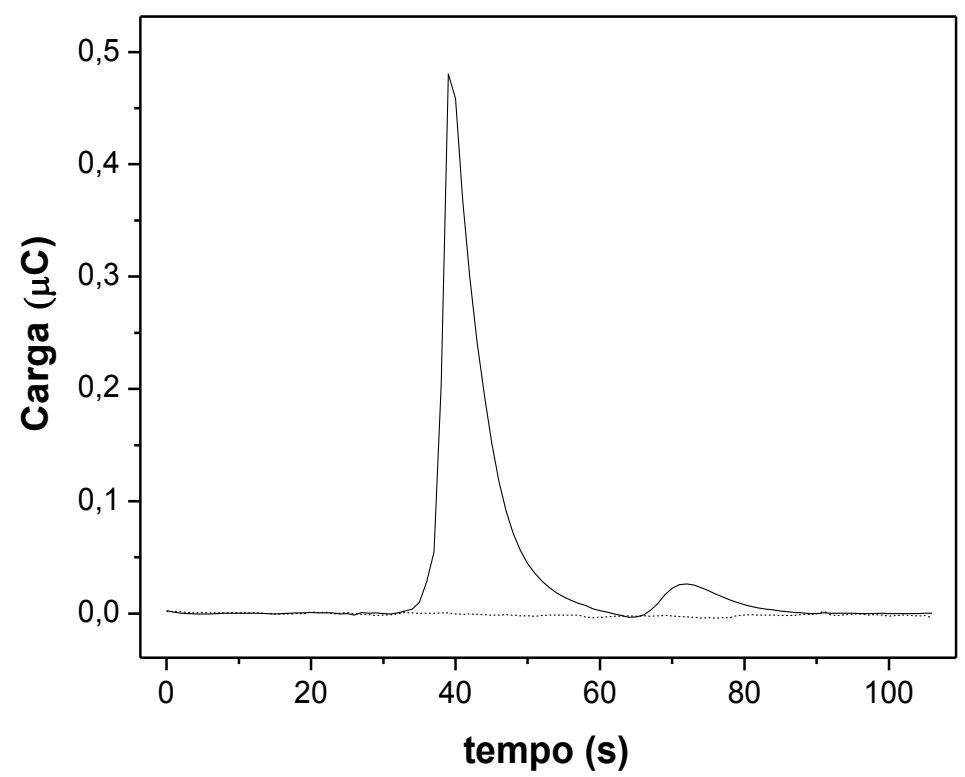

Figura 48. Eletroferograma de uma amostra de água potável fortificada com $100 \mu \mathrm{mol} \mathrm{L} \mathrm{L}^{-1}$ de glifosato e $500 \mu \mathrm{mol} \mathrm{L}{ }^{-1}$ de AMPA (linha cheia). Na linha tracejada é apresentado o eletroferograma da amostra sem fortificação.

\subsubsection{Conclusão}

Com base nos estudos eletroquímicos realizados em eletrodos convencionais de ouro e cobre, constatou-se uma maior sensibilidade eletroquímica para glifosato utilizando o metal cobre como eletrodo de trabalho.

O uso de eletrodos de trabalho confeccionados a partir de placas de circuito impresso veio a somar valores no conceito de baixo custo e simplicidade de metodologia, objetivados nesse trabalho. Apresentando um bom desempenho analítico, esses eletrodos supriram bem a necessidade de uso de eletrodos planares de cobre.

Fenômenos de superfície dependem fortemente de etapas de pré-condicionamento e limpeza prévia muito bem realizada. Nos processos eletroquímicos a atividade do substrato, é em muitas vezes, dependente das etapas de pré-tratamento de superfície. Dessa forma, quando comparado ao método desenvolvido utilizando $C^{4} \mathrm{D}$ para determinação de glifosato (capitulo 
3), o método apresentado nesse capitulo tem como principal desvantagem a necessidade de etapas exaustivas de limpeza e pré-condicionamento.

De um modo geral, os resultados obtidos nessa etapa do trabalho foram muito satisfatórios. O valor de LD encontrado para glifosato está de acordo com órgão regulamentador, tanto quanto uma boa repetibilidade e aplicabilidade foram obtidas. Além do bom desempenho analítico, características instrumentais fortalecem a ideia de portabilidade. A alimentação do minipotenciostato por baterias, o uso de microdispositivos e a possibilidade de ajuste de outros instrumentos necessários, favorecem o desenvolvimento de uma instrumentação completa para determinação de glifosato in situ. Dessa forma, a possibilidade citada acima fica como proposta de trabalhos futuros. 


\section{REFERÊNCIAS BIBLIOGRÁFICAS}

1. NGUYEN, N.; WERELEY, S. Fundamentals and applications of microfluidics. Boston: Artech House Publishers, 2002. 487 p.

2. TERRY, S. C.; JERMAN, J. H.; ANGELL, J. B. Gas-chromatographic air analyzer fabricated on a silicon-wafer. Ieee Transactions on Electron Devices, v. 26, n. 12, p. 18801886, 1979.

3. AUROUX, P. A.; IOSSIFIDIS, D.; REYES, D. R.; MANZ, A. Micro total analysis systems. 2. Analytical standard operations and applications. Analytical Chemistry, v. 74, n. 12, p. 2637-2652, 2002.

4. DITTRICH, P. S.; MANZ, A. Lab-on-a-chip: microfluidics in drug discovery. Nature Reviews Drug Discovery, v. 5, n. 3, p. 210-218, 2006.

5. BILITEWSKI, U.; GENRICH, M.; KADOW, S.; MERSAL, G. Biochemical analysis with microfluidic systems. Analytical and Bioanalytical Chemistry, v. 377, n. 3, p. 556-569, 2003.

6. PLAUT, O.; STAUB, C. Capillary electrophoresis in forensic toxicology. Chimia, v. 56, n. 3, p. 96-100, 2002.

7. FROST, M.; KOHLER, H.; BLASCHKE, G. Determination of LSD in blood by capillary electrophoresis with laser-induced fluorescence detection. Journal of Chromatography B, v. 693, n. 2, p. 313-319, 1997.

8. FILLET, M.; BECHET, I.; PIETTE, V.; CROMMEN, J. Separation of nonsteroidal antiinflammatory drugs by capillary electrophoresis using nonaqueous electrolytes.

Electrophoresis, v. 20, n. 9, p. 1907-1915, 1999.

9. LI, J.; FRITZ, J. S. Nonaqueous media for separation of nonionic organic compounds by capillary electrophoresis. Electrophoresis, v. 20, n. 1, p. 84-91, 1999.

10. ISSAQ, H. J.; CHAN, K. C.; MUSCHIK, G. M. The effect of column length, applied voltage, gel type, and concentration on the capillary electrophoresis separation of DNA fragments and polymerase chain reaction products. Electrophoresis, v. 18, n. 7, p. 11531158, 1997.

11. HOLLAND, L. A.; CHETWYN, N. P.; PERKINS, M. D.; LUNTE, S. M. Capillary electrophoresis in pharmaceutical analysis. Pharmaceutical Research, v. 14, n. 4, p. 372387, 1997.

12. THIBON, V. R. A.; BARTLE, K. D.; ABBOT, D. J.; MCCORMACK, K. A. Analysis of zinc dialkyl dithiophosphates by nonaqueous capillary electrophoresis and application to lubricants. Journal of Microcolumn Separations, v. 11, n. 1, p. 71-80, 1999.

13.WANG, H. L.; LU, M. L.; LE, X. C. DNA-driven focusing for protein-DNA binding assays using capillary electrophoresis. Analytical Chemistry, v. 77, n. 15, p. 4985-4990, 2005 . 
14. COLTRO, W. K. T.; PICCIN, E.; CARRILHO, E.; DE JESUS, D. P.; FRACASSI DA SILVA, J. A.; TORRES DA SILVA, H. D.; DO LAGO, C. L. Micro chemical analysis systems. Introduction, fabrication technologies, instrumentation and applications. Quimica Nova, v. 30, n. 8, p. 1986-2000, 2007.

15. HEIGER, D. N. High performance capillary electrophoresis: an introduction. Paris: Hewlett Packard Co, 1992. 135 p.

16. RODDY, E. S.; XU, H. W.; EWING, A. G. Sample introduction techniques for microfabricated separation devices. Electrophoresis, v. 25, n. 2, p. 229-242, 2004.

17. ALARIE, J. P.; JACOBSON, S. C.; RAMSEY, J. M. Electrophoretic injection bias in a microchip valving scheme. Electrophoresis, v. 22, n. 2, p. 312-317, 2001.

18. JACOBSON, S. C.; RAMSEY, J. M. Microchip electrophoresis with sample stacking. Electrophoresis, v. 16, n. 4, p. 481-486, 1995.

19. KOK, W. Capillary electrophoresis: instrumentation and operation. Wiesbaden: Vieweg Pub, 2000. 89 p.

20. TAVARES, M. Eletroforese capilar: conceitos básicos. Quimica Nova, v. 19, n. 2, p. 173-181, 1996.

21. BAKER, D. Capillary Electrophoresis. New York: John Wiley, 1995. 244 p

22. TAVARES, M. F. M.; COLOMBARA, R.; MASSARO, S. Modified electroosmotic flow by cationic surfactant additives in capillary electrophoresis - Evaluation of electrolyte systems for anion analysis. Journal of Chromatography A, v. 772, n. 1-2, p. 171-178, 1997.

23. KONSTANTINOU, I. K.; HELA, D. G.; ALBANIS, T. A. The status of pesticide pollution in surface waters (rivers and lakes) of Greece. Part I. Review on occurrence and levels. Environmental Pollution, v. 141, n. 3, p. 555-570, 2006.

24. CALDAS, E.; SOUZA, L. Avaliação de risco crônico da ingestão de resíduos de pesticidas na dieta brasileira. Revista de Saúde Pública, v. 34, n. 5, p. 529-537, 2000.

25. PIMENTEL, D. Amounts of pesticides reaching target pests - Environmental impacts and ethics. Journal of Agricultural \& Environmental Ethics, v. 8, n. 1, p. 17-29, 1995.

26. JOHNSON, D. C.; LACOURSE, W. R. Liquid chromatography with pulsed electrochemical detection at gold and platinum electrodes. Analytical Chemistry, v. 62, n. 10, p. 589-597, 1990.

27. AMARANTE JÚNIOR, O.; SANTOS, T.; BRITO, N.; RIBEIRO, M. Métodos de extração e determinação do herbicida glifosato: breve revisão. Quimica Nova, v. 25, n. 3, p. 420, 2002.

28. AMARANTE JUNIOR, O. P.; SANTOS, T. C. R.; BRITO, N. M.; RIBEIRO, M. L. Glifosato: propriedades, toxicidade, usos e legislação. Quimica Nova, v. 25, n. 4, p. 589, 2002. 
29. INTERNATIONAL SERVICE FOR THE ACQUISITION OF AGRI-BIOTECH APLICATIONS. Disponível em:

<http://www.isaaa.org/resources/publications/briefs/41/executivesummary/default.asp.> Acesso em: 12 set. 2010.

30. SANCHEZ-BAYO, F.; HYNE, R. V.; DESSEILLE, K. L. An amperometric method for the detection of amitrole, glyphosate and its aminomethyl-phosphonic acid metabolite in environmental waters using passive samplers. Analytica Chimica Acta, v. 675, n. 2, p. 125$131,2010$.

31. SPRANKLE, P.; MEGGITT, W. F.; PENNER, D. Adsorption, mobility, and microbial degradation of glyphosate in soil. Weed Science, v. 23, n. 3, p. 229-234, 1975.

32. ARAÚJO, A. S. F. Biodegradação, extração e análise de glifosato em dois tipos de solos. 83 f. Disssertação (Mestrado em Microbiologia Agrícola) - Escola Superior de Agricultura Luiz de Queiroz, Universidade de São Paulo, Piracicaba, 2002.

33. GOLDFRANK, L.; FLOMENBAUM, N. Goldfrank's toxicologic emergencies. New York: Mcgraw-Hill Professional, 2006. 1981 p.

34. GOODWIN, L.; STARTIN, J. R.; KEELY, B. J.; GOODALL, D. M. Analysis of glyphosate and glufosinate by capillary electrophoresis - mass spectrometry utilising a sheathless microelectrospray interface. Journal of Chromatography A, v. 1004, n. 1-2, p. 107-119, 2003.

35. BARJA, B. C.; HERSZAGE, J.; ALFONSO, M. D. Iron(III)-phosphonate complexes. Polyhedron, v. 20, n. 15-16, p. 1821-1830, 2001.

36. COUTINHO, C. F. B.; MAZO, L. H. Complexos metálicos com o herbicida glifosato: Revisão. Quimica Nova, v. 28, n. 6, p. 1038-1045, 2005.

37. MADSEN, H. E. L.; CHRISTENSEN, H. H.; GOTTLIEBPETERSEN, C. Stabilityconstants of copper(II), zinc, manganese(II), calcium, and magnesium complexes of n(phosphonomethyl)glycine (glyphosate). Acta Chemica Scandinavica Series a-Physical and Inorganic Chemistry, v. 32, n. 1, p. 79-83, 1978.

38. DOS SANTOS, V. M. R.; DONNICI, C. L.; DACOSTA, J. B. N.; CAIXEIRO, J. M. R. Compostos organofosforados pentavalentes: histórico, métodos sintéticos de preparação e aplicações como inseticidas e agentes antitumorais. Quimica Nova, v. 30, n. 1, p. 159-170, 2007.

39. COUTINHO, C. F. B.; TANIMOTO, S. T.; GALLI, A.; GARBELLINI, G. S.;

TAKAYAMA, M.; DO AMARAL, R. B.; MAZO, L. H.; AVACA, L. A.; MACHADO, S. A. S. Pesticidas: mecanismo de ação, degradação e toxidez. Pesticidas: Revista de

Ecotoxicologia e Meio Ambiente, v. 15, p. 66, 2005.

40. ALONZO, H. G. A.; CORRÊA, C. L. Fundamentos de toxicologia. São Paulo: Atheneu Editora, 2008. v. 3. 
41. GRANJA, C. U.; MELO, O. L.; SALCEDO, A.; CÉSPEDES, J. E.; SANTODOMINGO, T.; GASTELBONDO, Y.; CHIVATA, B. O. F. Reported human health effects from glyphosate. Bogota: Uribe Cualla Toxicology Clinic, 2001. 81 p.

42. COX, C. Herbicide factsheet: glyphosate. Journal of Pesticide Reform, v. 24, n. 4, p. 10$15,2004$.

43. CONSELHO NACIONAL DE MEIO AMBIENTE. Qualidade da água. Disponicel em: <http://www.mma.gov.br/port/conama/legiabre.cfm?codlegi=459/>. Acesso em: 18 set. de 2010 .

44. AMARANTE JÚNIOR, O. P.; DOS SANTOS, T. C. R. Métodos de extração e determinação do herbicida glifosato: Breve revisão. Quimica Nova, v. 25, n. 3, p. 589-593, 2002.

45. HIDALGO, C.; RIOS, C.; HIDALGO, M.; SALVADO, V.; SANCHO, J. V.; HERNANDEZ, F. Improved coupled-column liquid chromatographic method for the determination of glyphosate and aminomethylphosphonic acid residues in environmental waters. Journal of Chromatography A, v. 1035, n. 1, p. 153-157, 2004.

46. NEDELKOSKA, T. V.; LOW, G. K. C. High-performance liquid chromatographic determination of glyphosate in water and plant material after pre-column derivatisation with 9-fluorenylmethyl chloroformate. Analytica Chimica Acta, v. 511, n. 1, p. 145-153, 2004.

47. JIANG, J.; LUCY, C. A. Determination of glyphosate using off-line ion exchange preconcentration and capillary electrophoresis-laser induced fluorescence detection. Talanta, v. 72, n. 1, p. 113-118, 2007.

48. QIAN, K.; TANG, T.; SHI, T. Y.; WANG, F.; LI, J. Q.; CAO, Y. S. Residue determination of glyphosate in environmental water samples with high-performance liquid chromatography and UV detection after derivatization with 4-chloro-3,5-

dinitrobenzotrifluoride. Analytica Chimica Acta, v. 635, n. 2, p. 222-226, 2009.

49. KHROLENKO, M. V.; WIECZOREK, P. P. Determination of glyphosate and its metabolite aminomethylphosponic acid in fruit juices using supported-liquid membrane preconcentration method with high-performance liquid chromatography and UV detection after derivatization with p-toluenesulphonyl chloride. Journal of Chromatography A, v. 1093, n. 1-2, p. 111-117, 2005.

50. GAVLICK, W. K.; TOMKINS, D. F. An updated liquid chromatographic assay for the determination of glyphosate in technical material and formulations. Journal of Aoac International, v. 91, n. 1, p. 1-4, 2008.

51. SUN, Y. J.; WANG, C. Y.; WEN, Q. Y.; WANG, G. X.; WANG, H. H.; QU, Q. S.; HU, X. Y. Determination of Glyphosate and Aminomethylphosphonic Acid in Water by LC Using a New Labeling Reagent, 4-Methoxybenzenesulfonyl Fluoride. Chromatographia, v. 72, n. 7-8, p. 679-686, 2010.

52. BAUER, K. H.; KNEPPER, T. P.; MAES, A.; SCHATZ, V.; VOIHSEL, M. Analysis of polar organic micropollutants in water with ion chromatography electrospray mass spectrometry. Journal of Chromatography A, v. 837, n. 1-2, p. 117-128, 1999. 
53. MOTOJYUKU, M.; SAITO, T.; AKIEDA, K.; OTSUKA, H.; YAMAMOTO, I.; INOKUCHI, S. Determination of glyphosate, glyphosate metabolites, and glufosinate in human serum by gas chromatography-mass spectrometry. Journal of Chromatography BAnalytical Technologies in the Biomedical and Life Sciences, v. 875, n. 2, p. 509-514, 2008.

54. CHEN, Z. L.; HE, W. X.; BEER, M.; MEGHARAJ, M.; NAIDU, R. Speciation of glyphosate, phosphate and aminomethylphosphonic acid in soil extracts by ion chromatography with inductively coupled plasma mass spectrometry with an octopole reaction system. Talanta, v. 78, n. 3, p. 852-856, 2009.

55. BORJESSON, E.; TORSTENSSON, L. New methods for determination of glyphosate and (aminomethyl)phosphonic acid in water and soil. Journal of Chromatography A, v. 886, n. 1-2, p. 207-216, 2000.

56. IBANEZ, M.; POZO, O. J.; SANCHO, J. V.; LOPEZ, F. J.; HERNANDEZ, F. Residue determination of glyphosate, glufosinate and aminomethylphosphonic acid in water and soil samples by liquid chromatography coupled to electrospray tandem mass spectrometry.

Journal of Chromatography A, v. 1081, n. 2, p. 145-155, 2005.

57. SONGA, E. A.; AROTIBA, O. A.; OWINO, J. H. O.; JAHED, N.; BAKER, P. G. L.; IWUOHA, E. I. Electrochemical detection of glyphosate herbicide using horseradish peroxidase immobilized on sulfonated polymer matrix. Bioelectrochemistry, v. 75, n. 2, p. 117-123, 2009.

58. COUTINHO, C. F. B.; COUTINHO, L. F. M.; MAZO, L. H.; LANCAS, F. M. Copper microelectrode as liquid chromatography detector for herbicide glyphosate. Electroanalysis, v. 19, n. 11, p. 1223-1226, 2007.

59. MORAES, F.; MASCARO, L. H.; MACHADO, S. A. S.; BRETT, C. M. A. Direct Electrochemical Determination of Glyphosate at Copper Phthalocyanine/Multiwalled Carbon Nanotube Film Electrodes. Electroanalysis, v. 22, n. 14, p. 1586-1591, 2010.

60. CORBERA, M.; HIDALGO, A.; SALVADO, V.; WIECZOREK, P. P. Determination of glyphosate and aminomethylphosphonic acid in natural water using the capillary electrophoresis combined with enrichment step. Analytica Chimica Acta, v. 540, n. 1, p. 3-7, 2005.

61. IWAMURO, Y.; IIO-ISHIMARU, R.; CHINAKA, S.; TAKAYAMA, N.; KODAMA, S.; HAYAKAWA, K. Analysis of Phosphorus-containing Amino Acid-type Herbicides by Capillary Electrophoresis/Mass Spectrometry Using a Chemically Modified Capillary Having Amino Groups. Journal of Health Science, v. 56, n. 5, p. 606-612, 2010.

62. YANG, G. D.; XU, X. Q.; SHEN, M. C.; WANG, W.; XU, L. J.; CHEN, G. N.; FU, F. F. Determination of organophosphorus pesticides by capillary electrophoresis-inductively coupled plasma mass spectrometry with collective sample-introduction technique.

Electrophoresis, v. 30, n. 10, p. 1718-1723, 2009.

63. CHANG, S. Y.; LIAO, C. H. Analysis of glyphosate, glufosinate and aminomethylphosphonic acid by capillary electrophoresis with indirect fluorescence detection. Journal of Chromatography A, v. 959, n. 1-2, p. 309-315, 2002. 
64. HSU, C. C.; WHANG, C. W. Microscale solid phase extraction of glyphosate and aminomethylphosphonic acid in water and guava fruit extract using alumina-coated iron oxide nanoparticles followed by capillary electrophoresis and electrochemiluminescence detection. Journal of Chromatography A, v. 1216, n. 49, p. 8575-8580, 2009.

65. GAS, B.; DEMJANENKO, M.; VACIK, J. High-frequency contactless conductivity detection in isotachophoresis. Journal of Chromatography, v. 192, n. 2, p. 253-257, 1980.

66. ZEMANN, A. J.; SCHNELL, E.; VOLGGER, D.; BONN, G. K. Contactless conductivity detection for capillary electrophoresis. Analytical Chemistry, v. 70, n. 3, p. 563-567, 1998.

67. DA SILVA, J. A. F.; DO LAGO, C. L. An oscillometric detector for capillary electrophoresis. Analytical Chemistry, v. 70, n. 20, p. 4339-4343, 1998.

68. PUMERA, M. Contactless conductivity detection for microfluidics: Designs and applications. Talanta, v. 74, n. 3, p. 358-364, 2007.

69. KUBAN, P.; HAUSER, P. C. A review of the recent achievements in capacitively coupled contactless conductivity detection. Analytica Chimica Acta, v. 607, n. 1, p. 15-29, 2008.

70. DA SILVA, J. A. F.; GUZMAN, N.; DO LAGO, C. L. Contactless conductivity detection for capillary electrophoresis - Hardware improvements and optimization of the input-signal amplitude and frequency. Journal of Chromatography A, v. 942, n. 1-2, p. 249-258, 2002.

71. COLTRO, W. K. T. Detecção condutométrica sem contato: uma nova ferramenta para monitoramento de interações biomoleculares em microssistemas analíticos. 246 f. Tese (Doutorado em Química Analítica) - Instituto de Química de São Carlos, Universidade de São Paulo, São Carlos, 2008.

72. DO LAGO, C. L.; DA SILVA, H. D. T.; NEVES, C. A.; BRITO-NETO, J. G. A.; DA SILVA, J. A. F. A dry process for production of microfluidic devices based on the lamination of laser-printed polyester films. Analytical Chemistry, v. 75, n. 15, p. 3853-3858, 2003.

73. COLTRO, W. K. T.; DA SILVA, J. A. F.; DA SILVA, H. D. T.; RICHTER, E. M.; FURLAN, R.; ANGNES, L.; DO LAGO, C. L.; MAZO, L. H.; CARRILHO, E. Electrophoresis microchip fabricated by a direct-printing process with end-channel amperometric detection. Electrophoresis, v. 25, n. 21-22, p. 3832-3839, 2004.

74. COLTRO, W. K. T. Fabricação e avaliação de microdispositivos para eletroforese com detecção eletroquímica. 126 f. Dissertação (Mestrado em Química Analítica) - Instituto de Química de São Carlos, Universidade de São Paulo, São Carlos, 2004.

75. TAVARES, M. F. M. Mecanismos de separação em eletroforese capilar. Quimica Nova, v. 20, n. 5, p. 493-511, 1997.

76. SOGA, T.; IMAIZUMI, M. Capillary electrophoresis method for the analysis of inorganic anions, organic acids, amino acids, nucleotides, carbohydrates and other anionic compounds. Electrophoresis, v. 22, n. 16, p. 3418-3425, 2001.

77. POSPICHAL, J.; GEBAUER, P.; BOCEK, P. Measurement of mobilities and dissociation-constants by capillary isotachophoresis. Chemical Reviews, v. 89, n. 2, p. 419430, 1989. 
78. NUSSBAURNER, S.; FLEURY-SOUVERAIN, S.; RUDAZ, S.; BONNABRYA, P.; VEUTHEY, J. L. Determination of suxamethonium in a pharmaceutical formulation by capillary electrophoresis with contactless conductivity detection (CE-(CD)-D-4). Journal of Pharmaceutical and Biomedical Analysis, v. 49, n. 2, p. 333-337, 2009.

79. HUTCHINSON, J. P.; JOHNS, C.; BREADMORE, M. C.; HILDER, E. F.; GUIJT, R. M.; LENNARD, C.; DICINOSKI, G.; HADDAD, P. R. Identification of inorganic ions in post-blast explosive residues using portable $\mathrm{CE}$ instrumentation and capacitively coupled contactless conductivity detection. Electrophoresis, v. 29, n. 22, p. 4593-4602, 2008.

80. LUKACS, K. D.; JORGENSON, J. W. Capillary zone electrophoresis - Effect of physical parameters on separation efficiency and quantitation. Journal of High Resolution Chromatography \& Chromatography Communications, v. 8, n. 8, p. 407-411, 1985.

81. YU, H.; HE, F. Y.; LU, Y.; HU, Y. L.; ZHONG, H. Y.; XIA, X. H. Improved separation efficiency of neurotransmitters on a native printed capillary electrophoresis microchip simply by manipulating electroosmotic flow. Talanta, v. 75, n. 1, p. 43-48, 2008.

82. PROGRAMA livre para simulação de separações eletroforéticas e propriedades fisicoquímicas de diferentes substancias. Disponível em: <http://web.natur.cuni.cz/ gas/>. Acesso em: 20 jul. 2010.

83. COLTRO, W.; LUNTE, S.; CARRILHO, E. Comparison of the analytical performance of electrophoresis microchannels fabricated in PDMS, glass, and polyester toner.

Electrophoresis, v. 29, n. 24, p. 4928-4937, 2008.

84. NELSON, R. J.; PAULUS, A.; COHEN, A. S.; GUTTMAN, A.; KARGER, B. L. Use of peltier thermoelectric devices to control column temperature in high-performance capillary electrophoresis. Journal of Chromatography, v. 480, p. 111-127, 1989.

85. RIBEIRO, F.; FERREIRA, M.; MORANO, S.; SILVA, L.; SCHNEIDER, R. Validation spreadsheet: a new tool for estimating the analytical figures of merit for the validation of univariate methods. Quimica Nova, v. 31, n. p. 164-171, 2008.

86. MILLER, J. C.; MILLER, J. N. Statistics and chemometrics for analytical chemistry. United Kingdom: Prentice Hall, 2000. 233 p.

87. AGÊNCIA NACIONAL DE VIGILÂNCIA SANITÁRIA. Disponivel em: <http:/www.anvisa.gov.br/legis/index.htm>. Acesso em: 31 ago. 2010.

88. QUIRINO, J. P.; TERABE, S. Sample stacking of cationic and anionic analytes in capillary electrophoresis. Journal of Chromatography A, v. 902, n. 1, p. 119-135, 2000.

89. KUBAN, P.; HAUSER, P. C. Evaluation of microchip capillary electrophoresis with external contactless conductivity detection for the determination of major inorganic ions and lithium in serum and urine samples. Lab on a Chip, v. 8, n. 11, p. 1829-1836, 2008.

90. KUBAN, P.; HAUSER, P. C. Effects of the cell geometry and operating parameters on the performance of an external contactless conductivity detector for microchip electrophoresis. Lab on a Chip, v. 5, n. 4, p. 407-415, 2005. 
91. LEE, C. Y.; CHEN, C. M.; CHANG, G. L.; LIN, C. H.; FU, L. M. Fabrication and characterization of semicircular detection electrodes for contactless conductivity detector - CE microchips. Electrophoresis, v. 27, n. 24, p. 5043-5050, 2006.

92. MAHABADI, K. A.; RODRIGUEZ, I.; LIM, C. Y.; MAURYA, D. K.; HAUSER, P. C.; DE ROOIJ, N. F. Capacitively coupled contactless conductivity detection with dual topbottom cell configuration for microchip electrophoresis. Electrophoresis, v. 31, n. 6, p. 1063 $1070,2010$.

93. XU, Y.; LIANG, J.; LIU, H. T.; HU, X. G.; WEN, Z. Y.; WU, Y. J.; CAO, M. X. Characterization of a capacitance-coupled contactless conductivity detection system with sidewall electrodes on a low-voltage-driven electrophoresis microchip. Analytical and Bioanalytical Chemistry, v. 397, n. 4, p. 1583-1593, 2010.

94. WANG, J.; CHEN, G.; MUCK, A. Wall-jet conductivity detector for microchip capillary electrophoresis. Talanta, v. 78, n. 1, p. 207-211, 2009.

95. BRITO, N. M.; AMARANTE JUNIOR, O. P.; POLESE, L.; RIBEIRO, M. L. Validação de métodos analíticos: estratégia e discussão. Pesticidas: Revista de Ecotoxicologia e Meio Ambiente, v. 13, p. 129-143, 2003.

96. GROSSMAN, P.; COLBURN, J. Capillary electrophoresis: theory and practice. San Diego: Academic Press, 1992. 352 p.

97. JACOBSON, S. C.; KOUTNY, L. B.; HERGENRODER, R.; MOORE, A. W.; RAMSEY, J. M. Microchip capillary electrophoresis with an integrated postcolumn reactor. Analytical Chemistry, v. 66, n. 20, p. 3472-3476, 1994.

98. FORET, F.; KUSY, P. Microdevices in mass spectrometry. European Journal of Mass Spectrometry, v. 13, n. 1, p. 41-44, 2007.

99. LIU, B. F.; OZAKI, M.; UTSUMI, Y.; HATTORI, T.; TERABE, S. Chemiluminescence detection for a microchip capillary electrophoresis system fabricated in poly(dimethylsiloxane). Analytical Chemistry, v. 75, n. 1, p. 36-41, 2003.

100. DING, S. N.; XU, J. J.; CHEN, H. Y. Microchip capillary electrophoresis coupled with an end-column electrochemiluminescence detection. Talanta, v. 70, n. 2, p. 403-407, 2006.

101. WOOLlEY, A. T.; LAO, K. Q.; GLAZER, A. N.; MATHIES, R. A. Capillary electrophoresis chips with integrated electrochemical detection. Analytical Chemistry, v. 70, n. 4, p. 684-688, 1998.

102. JACKSON, D. J.; NABER, J. F.; ROUSSEL, T. J.; CRAIN, M. M.; WALSH, K. M.; KEYNTON, R. S.; BALDWIN, R. P. Portable high-voltage power supply and electrochemical detection circuits for microchip capillary electrophoresis. Analytical Chemistry, v. 75, n. 14, p. 3643-3649, 2003.

103. SCHWARZ, M. A.; GALLIKER, B.; FLURI, K.; KAPPES, T.; HAUSER, P. C. A twoelectrode configuration for simplified amperometric detection in a microfabricated electrophoretic separation device. Analyst, v. 126, n. 2, p. 147-151, 2001. 
104. LU, W. Z.; CASSIDY, R. M. Background-noise in capillary electrophoretic amperometric detection. Analytical Chemistry, v. 66, n. 2, p. 200-204, 1994.

105. PICCIN, E. Novas tecnologias para fabricação de microsistemas analíticos e detecção eletroquímica. $181 \mathrm{f}$. Tese (Doutorado em Química Analítica) - Instituto de Química de São Carlos, Universidade de São Paulo, São Carlos, 2008.

106. VANDAVEER, W. R.; PASAS-FARMER, S. A.; FISCHER, D. J.; FRANKENFELD, C. N.; LUNTE, S. M. Recent developments in electrochemical detection for microchip capillary electrophoresis. Electrophoresis, v. 25, n. 21-22, p. 3528-3549, 2004.

107. WANG, J. Electrochemical detection for microscale analytical systems: a review. Talanta, v. 56, n. 2, p. 223-231, 2002.

108. NAKANISHI, H.; NISHIMOTO, T.; ARAI, A.; ABE, H.; KANAI, M.; FUJIYAMA, Y.; YOSHIDA, T. Fabrication of quartz microchips with optical slit and development of a linear imaging UV detector for microchip electrophoresis systems. Electrophoresis, v. 22, n. 2, p. 230-234, 2001.

109. MARTIN, R. S.; RATZLAFF, K. L.; HUYNH, B. H.; LUNTE, S. M. In-channel electrochemical detection for microchip capillary electrophoresis using an electrically isolated potentiostat. Analytical Chemistry, v. 74, n. 5, p. 1136-+, 2002.

110. HOLLAND, L. A.; LUNTE, S. M. Postcolumn reaction detection with dual-electrode capillary electrophoresis-electrochemistry and electrogenerated bromine. Analytical Chemistry, v. 71, n. 2, p. 407-412, 1999.

111. ABDELGAWAD, M.; WHEELER, A. R. Rapid prototyping in copper substrates for digital microfluidics. Advanced Materials, v. 19, n. 1, p. 133 - 137, 2007.

112. COUTINHO, C. F. B.; COUTINHO, L. F. M.; LANCAS, F. M.; CAMARA, C. A. P.; NIRDORF, S. L.; MAZO, L. H. Development of instrumentation for amperometric and coulometric detection using ultramicroelectrodes. Journal of the Brazilian Chemical Society, v. 19, n. 1, p. 131-139, 2008.

113. SATO, K.; JIN, J. Y.; TAKEUCHI, T.; MIWA, T.; SUENAMI, K.; TAKEKOSHI, Y.; KANNO, S. Integrated pulsed amperometric detection of glufosinate, bialaphos and glyphosate at gold electrodes in anion-exchange chromatography. Journal of Chromatography A, v. 919, n. 2, p. 313-320, 2001.

114. WELCH, L. E.; LACOURSE, W. R.; MEAD, D. A.; JOHNSON, D. C.; HU, T. Comparison of pulsed coulometric detection and potential-sweep pulsed coulometric detection for underivatized amino-acids in liquid-chromatography. Analytical Chemistry, v. 61, n. 6, p. 555-559, 1989.

115. CLARKE, A. P.; JANDIK, P.; ROCKLIN, R. D.; LIU, Y.; AVDALOVIC, N. An integrated amperometry waveform for the direct, sensitive detection of amino acids and amino sugars following anion-exchange chromatography. Analytical Chemistry, v. 71, n. 14, p. 2774-2781, 1999. 
116. COUTINHO, C. F. B. Desenvolvimento de metodologia eletroanalítica para a determinação do herbicida glifosato. 116 f. Tese (Doutorado em Química Analítica) Instituto de Química, Universidade de São Paulo, São Carlos, 2008.

117. JOHNSON, D. C.; LACOURSE, W. R. Liquid-chromatography with pulsed electrochemical detection at gold and platinum-electrodes. Analytical Chemistry, v. 62, n. 10, p. A589-A597, 1990.

118. MORILLO, E.; MAQUEDA, C.; BEJARANO, M.; MADRID, L.; UNDABEYTIA, T. $\mathrm{Cu}$ (II)-Glyphosate system - A study by anodic-stripping voltammetry and the influence of $\mathrm{Cu}$ adsorption by montmorillonite. Chemosphere, v. 28, n. 12, p. 2185-2196, 1994.

119. STULIK, K.; PACAKOVA, V.; LE, K.; HENNISSEN, B. Amperometric flow detection with a copper working electrode response mechanism and application to various compounds. Talanta, v. 35, n. 6, p. 455-460, 1988.

120. COUTINHO, C.; COUTINHO, L.; MAZO, L. Estudo do comportamento eletroquímico de substâncias complexantes utilizando eletrodo de cobre. Química Nova, v. 32, n. 1, p. 2009.

121. LUO, P. F.; PRABHU, S. V.; BALDWIN, R. P. Constant potential amperometric detection at a copper-based electrode: Electrode formation and operation. Analytical Chemistry, v. 62, n. 7, p. 752-755, 1990.

122. LUO, P. F.; ZHANG, F. Z.; BALDWIN, R. P. Constant potential amperometric detection of underivatized amino-acids and peptides at a copper electrode. Analytical Chemistry, v. 63, n. 17, p. 1702-1707, 1991.

123. KOK, W. T.; BRINKMAN, U. A. T.; FREI, R. W. Amperometric detection of aminoacids in high-performance liquid-chromatography with a copper electrode. Journal of Chromatography, v. 256, n. 1, p. 17-26, 1983.

124. STULIK, K.; PACAKOVA, V.; WEINGART, M.; PODOLAK, M. Operational parameters of voltammetric high-performance liquid-chromatographic detectors with copper electrodes and application to a determination of some fodder biofactors. Journal of Chromatography, v. 367, n. 2, p. 311-321, 1986.

125. COUTINHO, C. F. B.; SILVA, M. O.; MACHADO, S. A. S.; MAZO, L. H. Influence of glyphosate on the copper dissolution in phosphate buffer. Applied Surface Science, v. 253, n. 6, p. 3270-3275, 2007.

126. PROGRAMA livre para simulação e análise de curvas de titulação potenciométricas, cálculos de $\mathrm{pH}$ e equilíbrio ácido-base (CURTIPOT). Disponível em: <http://www2.iq.usp.br/docente/gutz/Curtipot.html>. Acesso em: 26 set. 2010. 